\title{
FLOODS OF SEPTEMBER 15-16, 1992, IN THE THOMPSON, WELDON, AND CHARITON RIVER BASINS, SOUTH-CENTRAL IOWA
}

By David A. Eash and Barbara A. Koppensteiner

U.S. GEOLOGICAL SURVEY

Open-File Report 97-122

Prepared in cooperation with the

IOWA HIGHWAY RESEARCH BOARD and the PROJECT DEVELOPMENT DIVISION of the IOWA DEPARTMENT OF TRANSPORTATION (IOWA DOT Research Project HR-140) 


\section{U.S. DEPARTMENT OF THE INTERIOR BRUCE BABBITT, Secretary}

U.S. GEOLOGICAL SURVEY GORDON P. EATON, Director

For additional information write to:

District Chief

U.S. Geological Survey

Room 269, Federal Building

400 South Clinton Street

lowa City, lowa 52244
Copies of this report can be purchased from:

U.S. Geological Survey

Branch of Information Services

Box 25286, Denver Federal Center

Denver, Colorado 80225-0286 


\section{CONTENTS}

Abstract

Introduction

Purpose and scope

Acknowledgments.

Study area

Hydrologic data

Floodflow frequencies

Flood history

Floods of June 1947

Floods of August 6, 1959

Floods of July 4, 1981

Floods of September 15-16, 1992

Floods of July 5, 1993.

Profiles for the floods of September 15-16, 1992, in the Thompson, Weldon, and Chariton River Basins, south-central Iowa.

Appendix A. Peak stages and discharges for streamflow-gaging stations in the Thompson, Weldon, and

Chariton River Basins, south-central Iowa

Appendix B. Water-surface-elevation profiles for the Thompson, Weldon, and Chariton River Basins, south-central Iowa

Appendix C. Temporary bench marks and reference points in the Thompson, Weldon, and Chariton River

Basins, south-central Iowa

\section{FIGURES}

1. Map of the Thompson, Weldon, and Chariton River Basins showing location of bridge sites used in the

September 15-16, 1992, flood profiles and U.S. Geological Survey streamflow-gaging stations...

2. Map showing areal distribution of rainfall for the September 14-15, 1992, storm in south-central Iowa

3. Graph showing cumulative rainfall for September 14-15, 1992, at Beaconsfield, Derby, and

Greenfield, Iowa

4. Graph showing water-surface-elevation profiles for the Thompson River, river miles 2.24-106.10

5. Graphs showing water-surface-elevation profiles for the Thompson River,:

$5 \mathrm{~A}$. river miles $2.24-20$

$5 B$. river miles $20-40$

5 C. river miles $40-60$

$5 \mathrm{D}$. river miles $60-80$

5E. river miles $80-100$

5F. river miles $100-106.10$

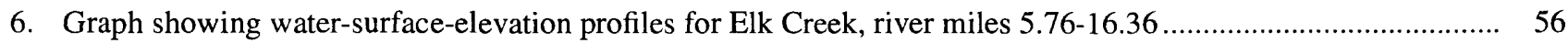

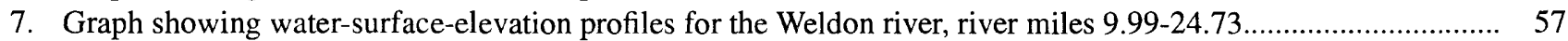

8. Graph showing water-surface-elevation profiles for the Chariton River, river miles 22.86-77.87....................... 58

9. Graphs showing water-surface-elevation profiles for the Chariton River,:

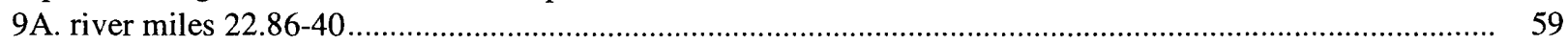

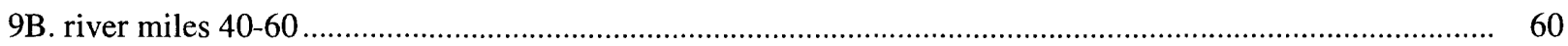

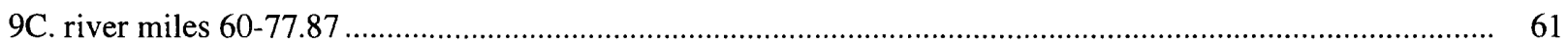

10. Graph showing water-surface-elevation profiles for the South Fork Chariton River, river miles 18.96-39.25 ....... 62 


\section{TABLES}

1. Floodflow frequencies for streamflow-gaging stations in the Thompson, Weldon, and Chariton

River Basins

2. Selected flood-peak discharges, recurrence intervals, and unit runoff for streamflow-gaging stations in the

Thompson, Weldon, and Chariton River Basins

CONVERSION FACTORS, ABBREVIATIONS, AND VERTICAL DATUM

\begin{tabular}{rll}
\hline Multiply & By & To obtain \\
\hline inch (in.) & & millimeter \\
foot $(\mathrm{ft})$ & 25.4 & meter \\
mile $(\mathrm{mi})$ & 0.3048 & kilometer \\
square mile $\left(\mathrm{mi}^{2}\right)$ & 2.509 & square kilometer \\
cubic meter per second \\
cubic meter per second \\
per square kilometer \\
cubic foot per second $\left(\mathrm{ft}^{3} / \mathrm{s}\right)$
\end{tabular}

Sea Level: In this report, "sea level" refers to the National Geodetic Vertical Datum of 1929--a geodetic datum derived from a general adjustment of the first-order level nets of the United States and Canada, formerly called Sea Level Datum of 1929. 


\title{
Floods of September 15-16, 1992, in the Thompson, Weldon, and Chariton River Basins, South-Central lowa
}

\author{
By David A. Eash and Barbara A. Koppensteiner
}

\section{ABSTRACT}

Water-surface-elevation profiles and peak discharges for the floods of September 15-16, 1992, in the Thompson, Weldon, and Chariton River Basins, south-central Iowa, are presented in this report. The profiles illustrate the 1992 floods along the Thompson, Weldon, Chariton, and South Fork Chariton Rivers and along Elk Creek in the south-central Iowa counties of Adair, Clarke, Decatur, Lucas, Madison, Ringgold, Union, and Wayne. Water-surface-elevation profiles for the floods of July 4, 1981, along the Chariton River in Lucas County and along the South Fork Chariton River in Wayne County also are included in the report for comparative purposes. The September 15-16, 1992, floods are the largest known peak discharges at gaging stations Thompson River at Davis City (station number 06898000) 57,000 cubic feet per second, Weldon River near Leon (station number 06898400 ) 76,200 cubic feet per second, Chariton River near Chariton (station number 06903400) 37,700 cubic feet per second, and South Fork Chariton River near Promise City (station number 06903700) 70,600 cubic feet per second. The peak discharges were, respectively, 1.7, 2.6, 1.4, and 2.1 times larger than calculated 100 -year recurrence-interval discharges. The report provides information on flood stages and discharges and floodflow frequencies for streamflow-gaging stations in the Thompson, Weldon, and Chariton River Basins using flood information collected through 1995. Information on temporary bench marks and reference points established in the Thompson and Weldon River Basins during 1994-95, and in the Chariton River Basin during 1983-84 and 1994-95, also is included in the report. A flood history summarizes rainfall conditions and damages for floods that occurred during 1947, 1959, 1981, 1992, and 1993.

\section{INTRODUCTION}

Evaluation of flood hazards and the planning, design, and operation of various structures on flood plains require information about floods. Flood-profile reports provide water-surface-elevation profiles and specific information for selected floods and are used by planners and engineers to evaluate the magnitude and frequency of floods in a river basin. This flood-profile report was prepared by the U.S. Geological Survey (USGS) in cooperation with the Iowa Highway Research Board and the Project Development Division of the Iowa Department of Transportation.

\section{Purpose and Scope}

This report presents water-surface-elevation profiles for the floods of September 15-16, 1992, in the Thompson, Weldon, and Chariton River Basins in south-central Iowa. Profiles for the floods of July 4, 1981, on the Chariton and South Fork Chariton Rivers also are presented in this report for comparative purposes. The report provides information on flood stages and discharges and floodflow frequencies for streamflow-gaging stations in the Thompson, Weldon, and Chariton River Basins using flood information collected through 1995. Information on temporary bench marks and reference points established in the Thompson and Weldon River Basins during 1994-95, and in the Chariton River Basin during 1983-84 and 1994-95, also is included in the report. A flood history summarizes rainfall conditions and damages for floods that occurred during 1947, 1959, 1981, 1992, and 1993. 


\section{Acknowledgments}

Various Federal, State, and local agencies cooperated in the collection of streamflow records used in this report, the acknowledgment of which is contained in the annual water-data reports of the USGS (U.S. Geological Survey, 1919-96). The authors express their gratitude to the following: B.R. Armstrong, P.S. Armstrong, A.J. Daley, R.F. Einhellig, E.E. Fischer, J.G. Gorman, G.F. Grimm, R.L. Kopish, P.D. Lustgraaf, T.C. Melcher, P.J. Soenksen, J.R. Sondag, D.M. Umphum, and J.J. Wellman for collecting the field data for the 1992 floods and surveying level-lines to establish sea-level elevations for the temporary bench marks and reference points; and T.L.

Birkenholtz for preparing the maps for this report.

\section{STUDY AREA}

The Thompson, Weldon, and Chariton River Basins are located in south-central Iowa (fig. 1) and drain into northern Missouri as part of the Missouri River Basin (not shown). The Thompson River Basin in Iowa is oriented in a general northwest-southeast direction, includes parts of six counties, and covers $729 \mathrm{mi}^{2}$ (Larimer, 1957, p. 123). The Thompson River is a left-bank tributary to the Grand River in Missouri (not shown). In Iowa, the Thompson River is known locally as the Grand River. The Weldon River Basin in Iowa is oriented in a general north-south direction, includes parts of three counties, and covers $240 \mathrm{mi}^{2}$ (Larimer, 1957, p. 124). The Weldon River is a leftbank tributary to the Thompson River in Missouri (not shown). The Chariton River Basin upstream of Rathbun Dam is oriented in a general west-east direction, includes parts of six counties, and covers $549 \mathrm{mi}^{2}$. Operation of Rathbun Dam (fig. 1) began in 1969. The Chariton River is a left-bank tributary to the Missouri River in Missouri (not shown). The South Fork Chariton River is a principal tributary to the Chariton River with a drainage area of $235 \mathrm{mi}^{2}$ (Larimer, 1957, p. 23).

Land use in south-central Iowa is primarily agricultural with some livestock operations. To provide flood protection and facilitate farming practices along the lower river valleys in south-central Iowa, several river channels in the Thompson, Weldon, and Chariton
River Basins were straightened. The majority of the channelization work occurred between 1905-20 (Iowa Natural Resources Council, 1958, p. 51-55). The Thompson River was channelized in Decatur County from downstream of Davis City to the Iowa-Missouri State line; major parts of the Weldon River and Steel Creek, a tributary of the Weldon River, were channelized in Decatur County; and the major part of the South Fork Chariton River in Wayne County was channelized.

The Thompson, Weldon, and Chariton River Basins lie within the Southern Iowa Drift Plain landform region of Iowa (Prior, 1991, p. 31-34). The Southern Iowa Drift Plain is characteristic of a postglacial landscape that has eroded to form a steeply to gently rolling topography and a well-established drainage system (Prior, 1991, p. 58-61; Iowa Natural Resources Council, 1958, p. 3-6; Cagle and Heinitz, 1978, p. 4-5). The Southern Iowa Drift Plain formed as a result of repeated continental glacial advances across southern Iowa, during which the bedrock surface of the uplands was smoothed and the valleys were filled with thick deposits of glacial till. Periods of glaciation were followed by interglacial periods of erosion. The sequence of repeated glacial scour and fill formed a nearly level drift plain across southern Iowa. The topography of southern Iowa developed as a result of the dissection of this drift plain; common terrain characteristics are integrated drainage networks, stepped erosional surfaces, and exposed bedrock in the deeper alluvial valleys (Prior, 1991, p. 34). South-central Iowa can be topographically divided into flood plains and terraces, uplands, and sideslopes; where well-developed flood plains and terraces occupy broad stream valleys underlain by alluvial deposits (Cagle and Heinitz, 1978, p. 4; Iowa Natural Resources Council, 1958, p. 6). The majority of the uplands are characterized as relatively rugged, moderately-to-highly dissected areas composed of hills, knobs, and ridges, but at places the uplands are gently rolling to slightly dissected. Nearly all of the upland soils of southern Iowa are formed from moderate deposits of wind-blown loess that subsequently covered the glacial tills. In general, soils in south-central Iowa are characterized as loess over clay loam till and clay paleosol; loess deposits in the area range from 75 to $200 \mathrm{in}$. (6.2 to $16.7 \mathrm{ft}$ ) (Oschwald and others, 1965, p. 6). 

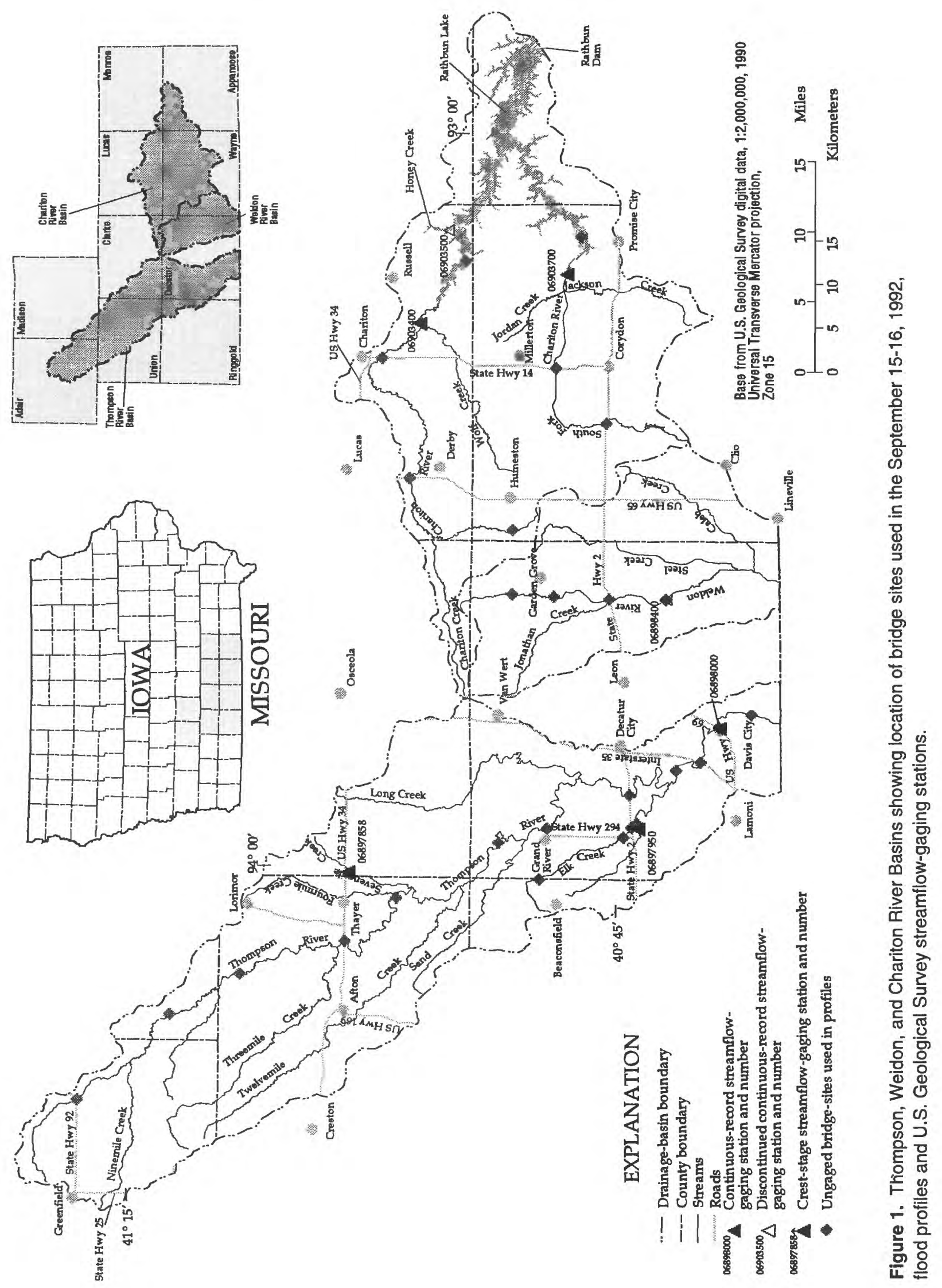


\section{HYDROLOGIC DATA}

Gaging-station records are the primary source of data for analyzing and understanding the flood hydrology of a river basin. Flood information is obtained from complete-record streamflow-gaging stations, which provide a continuous chronology of streamflow, and from partial-record, crest-stage streamflow-gaging stations, which provide a chronology of annual peakflows. The location of seven USGS gaging stations in the Thompson, Weldon, and Chariton River Basins are shown in figure 1; five are active gaging stations (three continuous-record gages and two crest-stage gages) and two are discontinued continuous-record gaging stations. The specific location, annual peak stages and discharges, and other information pertaining to each gaging station are presented in Appendix A. Discharge records collected during the operation of these gaging stations are published in the annual water-data reports of the USGS (U.S. Geological Survey, 1919-96).

The computation of discharge records at a gaging station is dependent upon the development of a stagedischarge relation, or rating curve, between watersurface elevations (stages) and the corresponding flow rates (discharges). The high-water part of the stagedischarge relation generally remains stable if the channel downstream from the gaging station remains unchanged. Changes in the stage-discharge relation occur from time to time, either gradually or abruptly, due to changes in the stream channel that result from scour, deposition, or the growth of vegetation (Rantz and others, 1982, p. 328-360).

Mean annual precipitation for 1961-90 at rain gages within and adjacent to the Thompson, Weldon, and Chariton River Basins (Owenby and Ezell, 1992, p. 22-24) are summarized in the table below.

\begin{tabular}{llllll}
\hline \multicolumn{6}{c}{ Rain gage and mean annual precipitation for 1961-90, } \\
in inches \\
\hline Beaconsfield & 33.93 & Creston & 34.79 & Leon & 35.79 \\
Chariton & 36.66 & Greenfield & 34.44 & Lorimor & 34.41 \\
Corydon & 35.99 & Lamoni & 36.70 & Osceola & 35.19 \\
\hline
\end{tabular}

Mean annual runoff in the Thompson, Weldon, and Chariton River Basins was determined at the following streamflow-gaging stations for the following water years (May and others, 1996, p. 222-224; O'Connell and others, 1992, p. 234).

\begin{tabular}{clcc}
\hline $\begin{array}{c}\text { Station } \\
\text { number }\end{array}$ & \multicolumn{1}{c}{ Station name } & $\begin{array}{c}\text { Period of } \\
\text { record } \\
\text { (water years) }\end{array}$ & $\begin{array}{c}\text { Mean } \\
\text { annual runoff, } \\
\text { in inches }\end{array}$ \\
\hline 06898000 & $\begin{array}{l}\text { Thompson River at } \\
\text { Davis City } \\
06898400\end{array}$ & $\begin{array}{l}1919-24, \\
1942-95\end{array}$ & 7.76 \\
& $\begin{array}{l}\text { Weldon River near } \\
\text { Leon }\end{array}$ & $1959-91$ & 9.06 \\
06903400 & $\begin{array}{l}\text { Chariton River near } \\
\text { Chariton }\end{array}$ & $1966-95$ & 9.46 \\
06903700 & $\begin{array}{l}\text { South Fork Chariton } \\
\text { River near Promise } \\
\text { City }\end{array}$ & $1968-95$ & 10.51 \\
\hline
\end{tabular}

\section{FLOODFLOW FREQUENCIES}

The magnitude and frequency of flood discharges, or floodflow frequencies, for a streamflowgaging station are determined from a flood-frequency curve which relates observed annual-peak discharges to annual exceedance probability or recurrence interval. Annual exceedance probability is expressed as the chance that a specified flood magnitude will be exceeded in any 1 year. Recurrence interval, which is the reciprocal of the annual exceedance probability, is the statistical average number of years between exceedances of a specified flood magnitude. For example, a flood with a magnitude that is expected to be exceeded on average once during any 100 -year period (recurrence interval) has a 1-percent chance (annual exceedance probability $=0.01$ ) of being exceeded during any 1 year. This flood, commonly termed the 100 -year flood, is the theoretical peak discharge against which actual flood peaks generally are compared. Although the recurrence interval represents the longterm average period between floods of a specific magnitude, rare floods could occur at shorter intervals or even within the same year.

Floodflow frequencies computed for a gaging station, and recurrence intervals determined for selected flood peaks, are statistics that can change as more data become available. Statistics become more reliable as more data are collected and used in the computations. USGS streamflow-gaging stations are the primary source of the streamflow data used in the computations presented in this report.

The method used in this report for determining floodflow frequencies from streamflow data is outlined in Bulletin 17B of the Interagency Advisory Committee on Water Data (1982, p. 1-28). The Interagency Advisory Committee recommends using the Pearson Type-III distribution with log transformation of the 
data, commonly known as the log-Pearson Type-III distribution, as a base method for determining floodflow frequencies. At least 10 years of gaged annualpeak discharges are required to compute floodflow frequencies using this method. In this report, this method for determining floodflow frequencies is referred to as the "Bulletin 17B" method.

Three methods for estimating floodflow frequencies at stream sites in Iowa, including those not gaged, are described by Lara (1987, p. 2-19) and Eash (1993, p. 9-41). Lara (1987) used the physiographic characteristics of Iowa as a guide in defining the boundaries of five hydrologic regions. Regional equations were developed by using the floodflow frequencies for all gaged stations in a hydrologically, homogeneous area, thereby reducing potential errors associated with nonrepresentative, short-term record stations. Eash (1993) developed two other methods for estimating floodflow frequencies for stream sites in Iowa. In one method, significant drainage-basin characteristics were related to the floodflow frequencies for 164 streamflow-gaging stations in Iowa. In the other method, significant onsite channel-geometry characteristics were related to the floodflow frequencies for 157 streamflow-gaging stations in Iowa. Both Lara and Eash used the Bulletin 17B method as the base method for developing their flood-estimation equations.

The floodflow frequencies computed using the Bulletin 17B method, the regional method of Lara (1987), and the drainage-basin and channel-geometry characteristic methods of Eash (1993) are listed in table 1 for the gaging stations in the Thompson, Weldon, and Chariton River Basins. Flood-frequency discharges computed using these four flood-estimation methods differ substantially for several of the gaging stations. Differences in computed discharges between the four methods result from inherent differences between the methods and from differences in the periods of streamflow record that were used in the computation of each method. Flood-frequency discharges computed using the Bulletin 17B method used streamflow data collected through the 1995 water year, the regional method developed by Lara used data collected through the 1984 water year, and the drainage-basin and channel-geometry methods developed by Eash used data collected through the 1990 water year. The significantly greater discharges computed using the Bulletin 17B method are primarily due to inclusion of the 1992 and 1993 floods in the computations. It is noted that different flood-frequency discharges might be computed by other agencies using the Bulletin 17B method if their analyses use different periods of record, different approaches to weighting the skewness (asymmetry) of the frequency distribution of the annual peak discharges, or different approaches to incorporation of historical flood information.

\section{FLOOD HISTORY}

Continuous records of streamflow have been collected in the Thompson River Basin in Iowa from May 1918 to July 1925 and since July 1941 at streamflowgaging station Thompson River at Davis City (station number 06898000 , fig. 1). Continuous records of streamflow have been collected in the Weldon River Basin in Iowa from October 1958 to September 1991 at gaging station Weldon River near Leon (station number 06898400 , fig. 1). Continuous records of streamflow have been collected in the Chariton River Basin upstream of Rathbun Dam since October 1965 at gaging station Chariton River near Chariton (station number 06903400, fig. 1) and since October 1967 at gaging station South Fork Chariton River near Promise City (station number 06903700, fig. 1). Appendix A contains a complete list of flood peaks for these and three other streamflow-gaging stations in the Thompson, Weldon, and Chariton River Basins. Selected floodpeak discharges, including maximum known floodpeak discharges, and recurrence intervals for the seven gaging stations are listed in table 2.

The Iowa Natural Resources Council (1958, p. 48) reports that historical records indicate that major flooding occurred along the Thompson River in Iowa in $1885,1897,1903,1909,1914,1915,1922,1924$, and 1926, but that information is meager regarding the magnitude of these early floods and the damage they caused. Prior to 1992, the greatest known flood in the Thompson River Basin occurred in 1885 (Schwob, 1953, p. 168; see appendix A). The Iowa Natural Resources Council (1958, p. 48) also reports that flooding occurred in the Chariton River Basin in 1892, 1903, $1909,1928,1939,1944,1945,1946$, and 1947. In general, because many cities and towns in south-central Iowa are located outside the flood plains of major streams, municipal flood damage is relatively low in comparison to agricultural and transportation flood damage; occasional flood damage occurs from small streams located within municipal limits (Iowa Natural Resources Council, 1958, p. 51). 
Table 1. Floodflow frequencies for streamflow-gaging stations in the Thompson, Weldon, and Chariton River Basins

[Water year, October 1-September 30; $\mathrm{mi}^{2}$, square mile; 17B, Bulletin 17B (Interagency Advisory Committee on Water Data, 1981); Lara, hydrologic-region flood-frequency equations (Lara, 1987, p. 28); DB, drainage-basin characteristic flood-frequency equations (Eash, 1993, p. 17); CG, channel-geometry characteristic flood-frequency equations (Eash, 1993, p. 25); --, not determined]

\begin{tabular}{|c|c|c|c|c|c|c|c|c|c|c|}
\hline \multirow{2}{*}{$\begin{array}{c}\text { Station } \\
\text { number } \\
\text { (fig. 1) }\end{array}$} & \multirow[b]{2}{*}{ Station name } & \multirow{2}{*}{$\begin{array}{c}\text { Drain- } \\
\text { age area } \\
\left(\mathbf{m i}^{2}\right)\end{array}$} & \multirow{2}{*}{$\begin{array}{l}\text { Period of } \\
\text { flood } \\
\text { record } \\
\text { a (water year) }\end{array}$} & \multirow[b]{2}{*}{ Method } & \multicolumn{6}{|c|}{$\begin{array}{l}\text { Discharge, in cubic feet per second, } \\
\text { for indicated recurrence interval, in years }\end{array}$} \\
\hline & & & & & 2 & 5 & 10 & 25 & 50 & 100 \\
\hline \multirow[t]{4}{*}{06897858} & \multirow{4}{*}{$\begin{array}{l}\text { Sevenmile Creek } \\
\text { near Thayer }\end{array}$} & \multirow[t]{4}{*}{6.61} & \multirow[t]{4}{*}{$1991-95$} & $17 \mathrm{~B}$ & -- & $\cdots$ & -- & -- & -- & -- \\
\hline & & & & ${ }^{\mathrm{b}}$ Lara & 575 & 1,140 & 1,610 & 2,280 & 2,780 & 3,350 \\
\hline & & & & $\mathrm{DB}$ & 604 & 1,180 & 1,650 & 2,290 & 2,810 & 3,370 \\
\hline & & & & CG & -- & -- & -. & -- & -- & -- \\
\hline \multirow[t]{4}{*}{06897950} & \multirow{4}{*}{$\begin{array}{l}\text { Elk Creek near } \\
\text { Decatur City }\end{array}$} & \multirow[t]{4}{*}{52.5} & \multirow{4}{*}{$\begin{array}{l}1959, \\
1967-95\end{array}$} & ${ }^{\mathrm{c}} 17 \mathrm{~B}$ & 5,730 & 12,400 & 17,100 & 23,000 & 27,000 & 30,800 \\
\hline & & & & ${ }^{\mathrm{d}}$ Lara & 1,500 & 2,740 & 3,640 & 4,900 & 5,900 & 6,940 \\
\hline & & & & DB & 3,080 & 5,460 & 7,280 & 9,660 & 11,600 & 13,500 \\
\hline & & & & ${ }^{\mathrm{e}} \mathrm{CG}$ & 3,150 & 6,010 & 8,210 & 11,400 & 13,800 & 16,700 \\
\hline \multirow[t]{4}{*}{06898000} & \multirow{4}{*}{$\begin{array}{l}\text { Thompson River } \\
\text { at Davis City }\end{array}$} & \multirow[t]{4}{*}{701} & \multirow{4}{*}{$\begin{array}{l}1885,1897, \\
1903,1909, \\
1914-15, \\
1918-26, \\
1941-95\end{array}$} & ${ }^{c} 17 \mathrm{~B}$ & 7,690 & 12,700 & 16,800 & 22,900 & 28,100 & 34,100 \\
\hline & & & & ${ }^{f}$ Lara & 5,450 & 9,470 & 12,400 & 16,200 & 19,000 & 22,200 \\
\hline & & & & DB & 11,400 & 17,900 & 22,600 & 28,200 & 32,500 & 36,800 \\
\hline & & & & ${ }^{\mathrm{g}} \mathrm{CG}$ & 7,790 & 13,200 & 17,100 & 22,300 & 26,300 & 30,200 \\
\hline \multirow[t]{4}{*}{06898400} & \multirow{4}{*}{$\begin{array}{l}\text { Weldon River } \\
\text { near Leon }\end{array}$} & \multirow[t]{4}{*}{104} & \multirow[t]{4}{*}{ 1959-92 } & $17 \mathrm{~B}$ & 5,810 & 10,200 & 13,800 & 19,300 & 24,200 & 29,700 \\
\hline & & & & ${ }^{\mathrm{d}}$ Lara & 2,300 & 4,100 & 5,380 & 7,140 & 8,530 & 9,980 \\
\hline & & & & DB & 3,740 & 6,410 & 8,400 & 10,900 & 12,900 & 14,900 \\
\hline & & & & ${ }^{\mathrm{g}} \mathrm{CG}$ & 4,370 & 7,770 & 10,300 & 13,800 & 16,600 & 19,300 \\
\hline \multirow[t]{4}{*}{06903400} & \multirow{4}{*}{$\begin{array}{l}\text { Chariton River } \\
\text { near Chariton }\end{array}$} & \multirow[t]{4}{*}{182} & \multirow{4}{*}{$\begin{array}{l}1947,1960 \\
1966-95\end{array}$} & $17 \mathrm{~B}$ & 4,000 & 7,830 & 11,200 & 16,400 & 21,100 & 26,500 \\
\hline & & & & ${ }^{f}$ Lara & 2,660 & 4,740 & 6,210 & 8,220 & 9,800 & 11,400 \\
\hline & & & & DB & 3,580 & 5,970 & 7,710 & 9,880 & 11,600 & 13,200 \\
\hline & & & & ${ }^{\mathrm{e}} \mathrm{CG}$ & 1,910 & 3,810 & 5,330 & 7,590 & 9,320 & 11,400 \\
\hline \multirow[t]{4}{*}{06903500} & \multirow{4}{*}{$\begin{array}{l}\text { Honey Creek } \\
\text { near Russell }\end{array}$} & \multirow[t]{4}{*}{13.2} & $1952-62$ & $17 \mathrm{~B}$ & 609 & 1,350 & 2,010 & 3,050 & 3,980 & 5,030 \\
\hline & & & & ${ }^{\mathrm{f}}$ Lara & 999 & 1,960 & 2,770 & 3,910 & 4,780 & 5,760 \\
\hline & & & & $\mathrm{DB}$ & 847 & 1,590 & 2,190 & 2,990 & 3,650 & 4,340 \\
\hline & & & & CG & -- & -- & -- & -- & -- & -- \\
\hline 06903700 & South Fork & 168 & 1965, & $17 \mathrm{~B}$ & 6,000 & 10,900 & 15,000 & 21,400 & 27,100 & 33,500 \\
\hline & Chariton River & & $1968-95$ & ${ }^{\mathrm{d}}$ Lara & 3,090 & 5,450 & 7,070 & 9,290 & 11,100 & 12,900 \\
\hline & near Promise & & & DB & 3,100 & 5,180 & 6,710 & 8,620 & 10,100 & 11,600 \\
\hline & Clity & & & ${ }^{\mathrm{g}} \mathrm{CG}$ & 3,150 & 5,760 & 7,760 & 10,500 & 12,800 & 15,000 \\
\hline
\end{tabular}

${ }^{\mathrm{a}}$ See Appendix A for list of flood peaks.

${ }^{\mathrm{b}}$ Flood-frequency equations for hydrologic region 2 were used.

${ }^{\mathrm{c}}$ Station skew, instead of weighted skew, was used in flood-frequency analysis.

${ }^{\mathrm{d}}$ Flood-frequency equations for hydrologic region 3 were used.

${ }^{\mathrm{e}} \mathrm{Flood}-$ frequency equations for region 1, bankfull were used.

${ }^{\mathrm{f}}$ Flood-frequency equations for hydrologic regions 2 and 3 were used based on weighted average, drainage-area ratios.

gFlood-frequency equations for region 1, active-channel were used. 
Table 2. Selected flood-peak discharges, recurrence intervals, and unit runoff for streamflow-gaging stations in the Thompson, Weldon, and Chariton River Basins

[ft, foot; $\mathrm{ft}^{3} / \mathrm{s}$, cubic foot per second; $\left(\mathrm{ft}^{3} / \mathrm{s}\right) / \mathrm{mi}^{2}$, cubic foot per second per square mile; *, maximum flood-peak discharge known for site; --, not determined]

\begin{tabular}{|c|c|c|c|c|c|c|}
\hline $\begin{array}{c}\text { Station } \\
\text { number } \\
\text { (fig. 1) }\end{array}$ & $\begin{array}{c}\text { Station } \\
\text { name }\end{array}$ & Date & $\begin{array}{c}\text { Gage height } \\
\text { a(ft) }\end{array}$ & $\begin{array}{c}\text { Discharge } \\
\left(\mathrm{ft}^{3} / \mathrm{s}\right)\end{array}$ & $\begin{array}{c}\text { Recurrence } \\
\text { interval } \\
\text { b(years) }\end{array}$ & $\begin{array}{l}\text { Unit runoff } \\
{\left[\left(\mathrm{ft}^{3} / \mathrm{s}\right) / \mathrm{mi}^{2}\right]}\end{array}$ \\
\hline \multirow[t]{2}{*}{06897858} & Sevenmile Creek near Thayer & $09-15-92$ & 24.92 & ${ }^{*} \mathrm{c}_{1,330}$ & -- & 201 \\
\hline & & $07-05-93$ & 23.49 & $\mathrm{c}_{1,220}$ & -- & 185 \\
\hline \multirow[t]{4}{*}{06897950} & Elk Creek near Decatur City & $08-06-59$ & $\mathrm{~d}_{30.5}$ to 32.5 & -- & -- & -- \\
\hline & & $07-20-90$ & 28.19 & $\mathrm{e}_{18,000}$ & 12 & 343 \\
\hline & & $09-15-92$ & 27.94 & 16,200 & 9 & 309 \\
\hline & & $07-05-93$ & 29.93 & $* 32,800$ & $\mathrm{f}_{1.1}$ & 625 \\
\hline \multirow[t]{6}{*}{06898000} & Thompson River at Davis City & $08-08-1885$ & $\mathrm{~g}, \mathrm{~h} 24.8$ & ${ }^{\mathrm{i}} 30,000$ & 60 & 42.8 \\
\hline & & $06-14-47$ & $\mathrm{~g}_{22.14}$ & $\mathrm{i}_{21,300}$ & 20 & 30.4 \\
\hline & & $08-06-59$ & $\mathrm{~g}_{20.42}$ & 17,500 & 11 & 25.0 \\
\hline & & $06-10-74$ & 19.43 & $i_{24,300}$ & 30 & 34.7 \\
\hline & & $09-16-92$ & 24.29 & $* 57,000$ & $\mathrm{f}_{1.7}$ & 81.3 \\
\hline & & $07-05-93$ & 20.53 & 30,300 & 70 & 43.2 \\
\hline \multirow[t]{2}{*}{06898400} & Weldon River near Leon & $08-06-59$ & $\mathrm{j}_{25.27}$ & $e, j_{48,600}$ & $\mathrm{f}_{1.6}$ & 467 \\
\hline & & $09-15-92$ & $\mathrm{~h}, \mathrm{k} 28.69$ & $* 176,200$ & $\mathrm{f}_{2.6}$ & 733 \\
\hline \multirow[t]{5}{*}{06903400} & Chariton River near Chariton & $06-05-47$ & $h_{21.65}$ & 11,000 & 10 & 60.4 \\
\hline & & $03-\cdots-60$ & $c_{23.0}$ & ${ }^{c} 15,000$ & 20 & 82.4 \\
\hline & & $07-04-81$ & 23.14 & 16,600 & 25 & 91.2 \\
\hline & & $09-15-92$ & $\mathrm{~h}_{29.32}$ & $* \mathrm{e}_{37,700}$ & $\mathrm{f}_{1.4}$ & 207 \\
\hline & & $07-05-93$ & 22.60 & 14,900 & 20 & 81.9 \\
\hline 06903500 & Honey Creek near Russell & $05-21-59$ & 11.26 & ${ }^{*} \mathrm{e}_{4,100}$ & 50 & 311 \\
\hline \multirow[t]{4}{*}{06903700} & South Fork Chariton River near & $09-21-65$ & $\mathrm{~h}_{25.5}$ & ${ }^{c} 18,000$ & 16 & 107 \\
\hline & Promise City & $07-04-81$ & 29.95 & 28,000 & 60 & 167 \\
\hline & & $09-15-92$ & $\mathrm{~h}_{34.84}$ & ${ }^{*} \mathrm{e}_{70,600}$ & $\mathrm{f}_{2.1}$ & 420 \\
\hline & & $07-05-93$ & 25.09 & 16,900 & 14 & 101 \\
\hline
\end{tabular}

${ }^{a}$ See Appendix A for datum of gage above sea level for continuous-record streamflow-gaging stations.

${ }^{\mathrm{b}}$ Interpolated from Bulletin 17B flood-frequency analysis (Interagency Advisory Committee on Water Data, 1981) and rounded to the nearest 5 years for 20- to 50-year recurrence intervals and to the nearest 10 years above the 50-year recurrence interval.

${ }^{\mathrm{c}}$ Approximate.

${ }^{\mathrm{d}}$ Referenced to present datum; prior to October 1, 1974, datum was $10.00 \mathrm{ft}$ higher. Flood stage information provided by Decatur County Assistant Engineer.

${ }^{\mathrm{e}}$ Discharge computed from indirect measurement.

${ }^{\mathrm{f}}$ Recurrence interval discharge larger than the computed 100-year flood is expressed as a ratio of the given flood discharge to the 100 -year flood discharge.

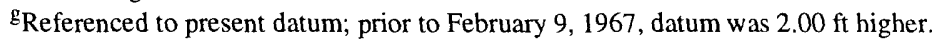

${ }^{\text {h }}$ Gage height determined from floodmarks.

${ }^{\mathrm{i}}$ Discharge determined from rating-curve extension on basis of velocity-area study.

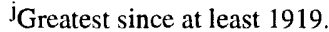

${ }^{\mathrm{k}}$ Gage height affected by backwater.

'Discharge estimated by drainage-ares ratio transfer of discharge computed from indirect measurement of September 15, 1992, flood at State Highway 2 bridge crossing the Weldon River. 


\section{Floods of June 1947}

Severe flooding that affected much of Iowa during June 1947 also involved south-central Iowa. Frequent rains and cool, cloudy weather during April and May saturated soils in the area prior to the flooding. Excessive rain fell over most of southern Iowa the night of June 45 , followed by lighter rains through June 7 th. Average rainfall over the area was about 3.5 in. (Iowa Natural Resources Council, 1958, p. 48). Rainfall amounts recorded during June 5-6, 1947 (U.S. Department of Commerce, Weather Bureau, and Iowa Department of Agriculture, 1947, p. 69), are listed in the table below. Runoff from the storms caused general flooding of all streams throughout south-central Iowa.

\begin{tabular}{llll}
\hline \multicolumn{4}{c}{ Rain gage and rainfall for June 5-6, 1947, in inches } \\
\hline Afton & 2.84 & Lamoni & 3.64 \\
Chariton & 4.78 & Millerton & 4.00 \\
Creston & 3.60 & Osceola & 2.87 \\
Greenfield & 3.35 & & \\
\hline
\end{tabular}

At the Chariton River near Chariton streamflowgaging station, the peak discharge $\left(11,000 \mathrm{ft}^{3} / \mathrm{s}\right)$ and stage $(21.65 \mathrm{ft}$ ) for the flood of June 5, 1947 (table 2), are both the fifth largest known at this site during 1947-95. The flood-peak discharge of $11,000 \mathrm{ft}^{3} / \mathrm{s}$ at the Chariton gage has a recurrence interval of approximately 10 years (table 2). At the Thompson River at Davis City gaging station, the peak discharge recorded on June 6,1947, was $19,500 \mathrm{ft}^{3} / \mathrm{s}$ and the peak stage was $19.3 \mathrm{ft}$ (see Appen$\operatorname{dix}$ A).

During June 11-12, 1947, intense rainfall occurred over mainly the western part of south-central Iowa. Streams throughout the area again rose rapidly and overflowed their banks. Rainfall amounts recorded during June 12-13, 1947 (U.S. Department of Commerce, Weather Bureau, and Iowa Department of Agriculture, 1947, p. 69) are listed in the table below.

\begin{tabular}{|c|c|c|c|}
\hline \multicolumn{4}{|c|}{ Rain gage and rainfall for June $12-13,1947$, in inches } \\
\hline Afton & 3.12 & Lamoni & 2.21 \\
\hline Creston & 4.12 & Osceola & 3.54 \\
\hline Greenfield & 4.84 & & \\
\hline
\end{tabular}

As a result of the second storm, the Thompson River at Davis City crested at a higher peak stage (20.14 ft) on June 14, 1947 (see Appendix A; or $22.14 \mathrm{ft}$ when referenced to present datum, table 2). The peak discharge of $21,300 \mathrm{ft}^{3} / \mathrm{s}$ for the flood of June 14,1947 , has a recurrence interval of approximately 20 years and is the fifth largest recorded discharge at this site during 18851995 (table 2). Discharges were not determined for four floods that occurred prior to operation of the Davis City gage (gage operation began May 1918) for which peak stages were reported to be higher than the peak stage of $20.14 \mathrm{ft}$ recorded for the 1947 flood (see Appendix A).

According to estimates calculated by the U.S. Army Corps of Engineers, the June 1947 floods exceeded all other previous floods in south-central Iowa in magnitude of flood damages (Iowa Natural Resources Council, 1958, p. 51). Damage from the 1947 floods was predominantly agricultural; major non-agricultural damage was to highways and roads. Flood damage data compiled by the U.S. Army Corps of Engineers and published by the Iowa Natural Resources Council (1958, p. 51), reports that the June 1947 floods inundated 47,720 acres in the Grand River Basin in Iowa, and caused \$1,814,200 of agricultural damage and $\$ 233,950$ of non-agricultural damage. In the Iowa Natural Resources Council report (1958), the Grand River Basin in Iowa includes the Thompson, Weldon, and Grand River Basins (the Grand River is not shown and is located west of the Thompson River). The floods inundated 39,140 acres in the Chariton River Basin in Iowa, and caused \$1,572,450 of agricultural damage and $\$ 83,750$ of non-agricultural damage.

\section{Floods of August 6, 1959}

The August 6, 1959, floods in south-central Iowa occurred as a result of excessive rainfall over Clarke, Decatur, Ringgold, Union, and Wayne Counties during the night of August 5-6, 1959, following moderate rainfall the preceding day. The following information pertaining to precipitation and damages for the August 6, 1959, floods was obtained from the U.S. Department of Commerce, Weather Bureau, and Iowa Department of Agriculture (1959, p. 122 and 125-127). Official rainfall amounts recorded on August 6,1959, are listed in the table below.

\begin{tabular}{lccc}
\hline \multicolumn{4}{c}{ Rain gage and rainfall for August 6, 1959, in inches } \\
\hline Afton & 0.65 & Lamoni & 1.86 \\
Beaconsfield & 5.85 & Lorimor & 4.45 \\
Corydon & 3.62 & Osceola & 3.80 \\
Creston & 3.85 & & \\
\hline
\end{tabular}


The center of the storm was along the Iowa-Missouri State line and in the general area of Leon, Davis City, and Lineville, Iowa. A study of weather-radar data, recording rain-gage charts, and reports by local residents indicated that rainfall occurred from about 9 p.m. on August 5th to 6 a.m. on August 6th; highintensity rainfall was reported to have occurred between 10 p.m. and 2 a.m. Unofficial rainfall data (including "bucket survey" data) collected throughout the five-county area immediately following the storm by the U.S. Army Corps of Engineers and the Weather Bureau ranged from 3 to more than 16 in. The greatest unofficial rainfall reports were from southeastern, central, and eastern Decatur County and southwestern Wayne County, where rainfall amounts ranged from 8 to more than 16 in.; the greatest unofficial rainfall amount reported was 16.70 in. in southeastern Decatur County.

Damage from the floods was estimated to be in the millions of dollars. The U.S. Highway Commission estimated $\$ 144,000$ damage to primary, secondary, and local county roads. In Decatur County, the County Conservationist estimated 32,000 to 34,000 acres of land ( 80 percent in row crops) were severely damaged.

At the Elk Creek near Decatur City streamflowgaging station, information on the 1959 flood obtained from the Decatur County Assistant Engineer prior to operation of the gage (gage operation began October 1967), indicates that the peak stage of the 1959 flood is the greatest known at this site during 1959-95 (table 2). At the Thompson River at Davis City gaging station, the peak discharge $\left(17,500 \mathrm{ft}^{3} / \mathrm{s}\right)$ for the flood of August 6, 1959 (table 2), is the sixth largest known discharge during 1885-1995. Discharges were not determined for five floods that occurred prior to operation of the Davis City gage (gage operation began May 1918) for which peak stages were reported to be higher than the peak stage of $18.42 \mathrm{ft}$ recorded for the 1959 flood (see Appendix A; or $20.42 \mathrm{ft}$ when referenced to present datum, table 2). The flood-peak discharge at Davis City of $17,500 \mathrm{ft}^{3} / \mathrm{s}$ has a recurrence interval of approximately 11 years (table 2). At the Weldon River near Leon gaging station, the peak discharge $\left(48,600 \mathrm{ft}^{3} / \mathrm{s}\right)$ and stage $(25.27 \mathrm{ft})$ for the flood of August 6, 1959 (table 2), are both the second largest known at this site during 1919-92. The flood-peak discharge of $48,600 \mathrm{ft}^{3} / \mathrm{s}$ computed from an indirect measurement at the Leon gage is 1.6 times larger than the Bulletin 17B, 100-year recurrence-interval discharge (table 2).

\section{Floods of July 4, 1981}

Flooding in south-central Iowa during July 3-5, 1981 , occurred as a result of excessive rainfall during July 3 rd and 4th, after much of the area had received up to 4 in. of rain less than a week earlier. Flooding was significant in the Chariton River Basin on July 4th, and in basins bordering the Chariton River Basin to the north during July 3-5, 1981. Additional information on the floods of July 1981 is presented in the report "Floods in South-Central Iowa" (Heinitz, 1986). Official rainfall amounts recorded on July 4, 1981, are listed in the table below; unofficial rainfall amounts of 10 to 12 in. were reported for the storm (U.S. Department of Commerce, National Oceanic and Atmospheric Administration, and Iowa Weather Service, 1981, p. 10 and 34).

\begin{tabular}{lclc}
\hline \multicolumn{4}{c}{ Rain gage and rainfall for July 4, 1981, in inches } \\
\hline Chariton & 5.48 & Osceola & 6.01 \\
Corydon & 7.16 & Rathbun Dam & 4.11 \\
\hline
\end{tabular}

The Agricultural Stabilization and Conservation Service (ASCS) Emergency Board estimated agricultural damage as a result of the flooding exceeded $\$ 68$ million in a 10 -county area that included Appanoose, Clarke, Davis (not shown, located east of Appanoose County), Decatur, Lucas, Madison, Marion, Monroe, Warren, and Wayne Counties (U.S. Department of Commerce, National Oceanic and Atmospheric Administration, and Iowa Weather Service, 1981, p. 34). In Lucas County, the State Highway 14 bridge crossing the Chariton River south of Chariton was closed during the flood (Des Moines Register, July 5, 1981). Dennis Reger, Lucas County Soil Conservationist, reported that unofficial rainfall amounts on July 3 rd of 5 to 12 in. caused a significant number of terraces to overtop, or to have siltation; damage to soybean and corn crops was significant, and soil losses in Lucas County were estimated to be 30 to 50 tons per acres (Des Moines Register, July 7, 1981). Wayne County agricultural officials reported that unofficial rainfall amounts were as high as $10 \mathrm{in}$. in one area of the county; crop damage in Wayne County was estimated to be nearly $\$ 8$ million, including $\$ 60,000$ of hay that was washed-away; Rolley Glasgon, Wayne County Engineer, reported that seven bridges in Wayne County were destroyed by the flooding and that damage in the county was estimated to exceed $\$ 1$ million; 
damage in Wayne County to corn and soybean crops was estimated to be nearly $\$ 100,000$ and $\$ 300,000$, respectively (Des Moines Register, July 7, 1981).

At the Chariton River near Chariton streamflowgaging station, the peak discharge $\left(16,600 \mathrm{ft}^{3} / \mathrm{s}\right)$ and stage ( $23.14 \mathrm{ft}$ ) for the flood of July 4, 1981 (table 2), are both the second largest known at this site during 1947-95. The flood-peak discharge of $16,600 \mathrm{ft}^{3} / \mathrm{s}$ has a recurrence interval of approximately 25 years (table 2). At the South Fork Chariton River near Promise City gaging station, the peak discharge $\left(28,000 \mathrm{ft}^{3} / \mathrm{s}\right)$ and stage $(29.95 \mathrm{ft})$ for the flood of July 4, 1991, are both the second largest known at this site during 1965-95. The flood-peak discharge of $28,000 \mathrm{ft}^{3} / \mathrm{s}$ has a recurrence interval of approximately 60 years (table 2 ).

\section{Floods of September 15-16, 1992}

The largest flood on record in the Thompson and Weldon River Basins in Iowa and in the Chariton River Basin upstream of Rathbun Dam occurred during September 15-16, 1992. The majority of the following information pertaining to precipitation for the September 15-16, 1992, floods was obtained from the U.S. Department of Commerce, National Oceanic and Atmospheric Administration, and Iowa Department of Agriculture and Land Stewardship (1992, Climatological data, p. 8 and 30-31), U.S. Department of Commerce, National Oceanic and Atmospheric Administration, and National Weather Service (1992, Storm summary report, p. 4-5), and Harry Hillaker, State Climatologist, Iowa Department of Agriculture and Land Stewardship (oral and written commun., January 1993). The flooding occurred as a result of thunderstorms that moved into south-central Iowa about midmorning on September 14th and continued to redevelop over the same area until about noon on the 15 th; the majority of the rain fell between 7 p.m. and 5 a.m. Soils in south-central Iowa were already saturated on September 14th when the storms began. Rainfall ranging from 5 to more than $11 \mathrm{in}$. was common over most of the Thompson and Weldon River Basins in Iowa and over the Chariton River Basin upstream of Rathbun Dam (fig. 2). The greatest rainfall was centered over Clarke, Decatur, Lucas, and Wayne Counties in the headwaters of the Weldon, Chariton, and South Fork Chariton Rivers (fig. 2). Official rainfall amounts recorded on September 15-16, 1992, are listed in the table below. The greatest rainfall amount reported for the storm was an unofficial 16 in. at Van Wert in Decatur County. Other unofficial rainfall reports included 10-13 in. near Chariton, 10 in. at Creston, 13 in. near Millerton in Wayne County, and 14 in. at Thayer in Union County.

\begin{tabular}{lrlr}
\hline \multicolumn{4}{l}{ Rain gage and rainfall for September 15-16, 1992, in inches } \\
\hline Beaconsfield & 8.32 & Leon & 7.34 \\
Chariton & 7.21 & Lorimor & 9.01 \\
Clio & 5.93 & near Promise City & 11.05 \\
Derby & 12.06 & & \\
Greenfield & 8.24 & Osceola & 9.41 \\
\hline
\end{tabular}

A total of 9.3 in. of rain fell at Derby between 11:00 p.m. and 5:30 a.m. during September 14-15, 1992 (fig. 3) (Fischer, 1993, p. 1855 and 1857). The average rainfall intensity for this 6.5 -hour period was 1.4 in. per hour. The maximum intensity was 1.2 in. in 15 minutes, which occurred between 11:00 and 11:15 p.m. Rainfall on September 14-15, 1992, exceeded the 100-year, 24-hour recurrence-interval rainfall amount in parts of at least 12 counties. Derby reported $11.7 \mathrm{in}$. of rain in a 24 -hour period ending at 9 a.m. on the 15 th, which at the time, was the fifth greatest official 24-hour rainfall ever recorded in Iowa. The 16 in. of rainfall reported at Van Wert was 2.1 times larger than the 100-year, 24-hour recurrenceinterval rainfall amount for the area of $7.74 \mathrm{in}$.

The following information in this section pertaining to inundation and damage for the floods of September 15-16, 1992, was obtained from the U.S. Department of Commerce, National Oceanic and Atmospheric Administration, and National Weather Service, 1992 (Storm summary report, p. 4-5) and the Des Moines Register (September 16, 17, and 19, 1992, newspaper articles).

During the floods, small creeks became torrents, while rivers quickly became lakes; some of the rivers swelled to as wide as $5 \mathrm{mi}$. By 9:10 a.m., on September 15,1992 , flood warnings were issued by the National Weather Service for Clarke, Decatur, Lucas, Monroe, Union, Wapello (not shown, located east of Monroe County), and Wayne Counties. Nearly all rivers and streams in these counties had serious flooding. Many highways and county roads in south-central Iowa were inundated and closed during the floods. At least 30 bridges in the area were destroyed by the floodwaters, damages to those bridges alone exceeded $\$ 10$ mil- 


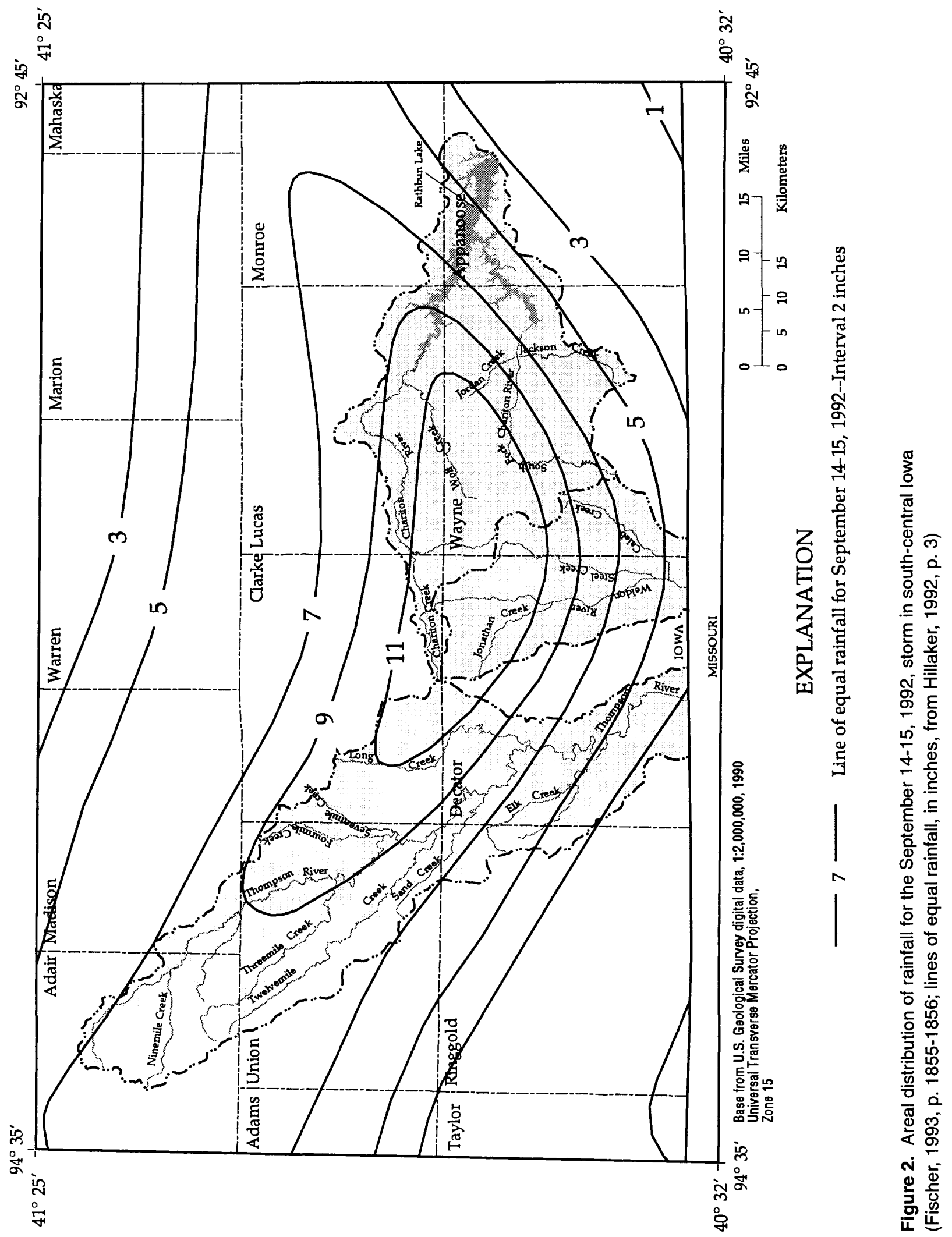




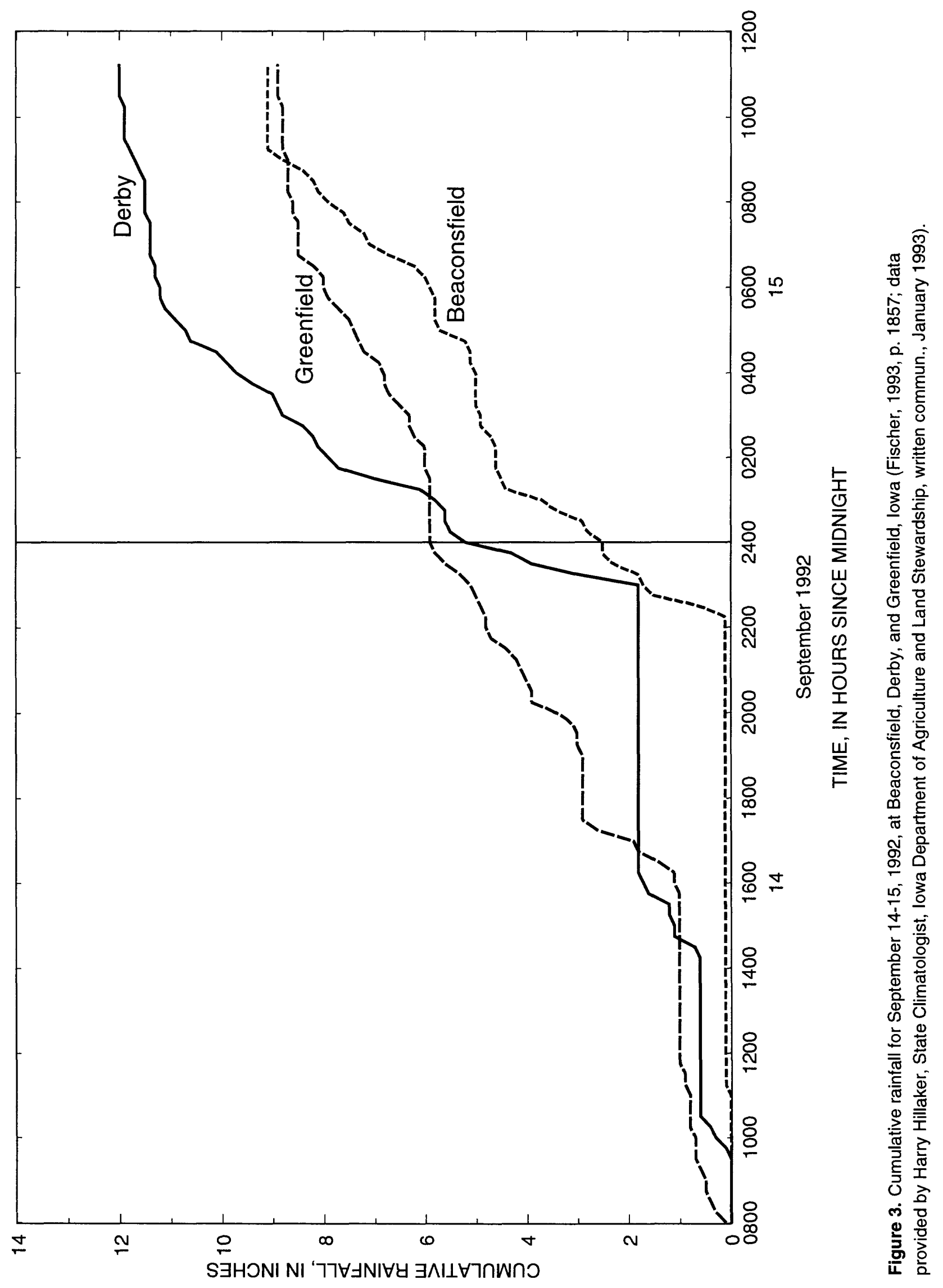


lion dollars. Floodwaters caused scour damage at many other bridges throughout the area; Fischer $(1993,1995)$ documented contraction scour at the State Highway 2 bridge crossing the Weldon River in Decatur County and at the State Highway 14 bridge crossing Wolf Creek in Lucas County (fig. 1). Road closures caused a few towns to be isolated during the flooding. The flooding interrupted Amtrak and freight-train traffic on the Burlington Northern Railroad across southern Iowa and forced rail traffic to be rerouted during September 1517,1992 . Because the floods occurred at the end of the growing season, crop damage was severe. Many crops were washed-away or flattened by the flooding. Agricultural officials estimated that thousands of acres of crops were damaged or destroyed, and that crop yields were reduced on about 147,000 acres in a 13-county area. Damage from the floods was extensive to both public and private property. Many homes were flooded and several school districts were closed for 2 days due to high water and flooded schools. No one was killed or seriously injured by the flooding; however, 25 head of sheep and 225 head of cattle were swept away and drowned. Information pertaining to road closures and damages resulting from the September 15-16, 1992, floods were reported for the following counties.

In Adair County, county roads along the Thompson River downstream of State Highway 92 were closed during the floods. In Clarke County, U.S. Highway 69 was closed during the floods from 2 to $8 \mathrm{mi}$ south of Osceola. Richard McKnight, Clarke County Assistant Engineer, reported that the floods completely destroyed three bridges, severely damaged 38 other bridges, and damaged 70 to $100 \mathrm{mi}$ of roads in the county; dirt roads, that are important to farmers during the fall harvest, were not included as part of the reported road damage. Officials in Clarke County estimated that damage to bridges and roads was at least $\$ 1$ million. Bart Griffith, Clarke County ASCS, reported that about 5,000 out of 60,000 acres of cropland in the county were flooded.

In Decatur County, Interstate 35 was closed where it crosses the Thompson River for about a day and one half during the flood, this was the first time the interstate had ever been closed due to flooding. State Highway 2 also was closed west of the interstate. Keith Hinds, Decatur County Assistant Engineer, reported that 10 bridges in the county were destroyed by the floods at a cost of about $\$ 1.1$ million, and that damage to roads was estimated at $\$ 150,000$. Twenty-five other bridges in the county were severely damaged. Alan
Hilleman, Decatur County ASCS Executive Director, reported that about 90 to 95 percent of the bottomland in the county was severely affected by the flooding. Hilleman and other agricultural officials estimated that 35,000 acres of corn and soybeans were inundated, or about 18 percent of the 197,800 acres of cropland in the county.

In Lucas County, U.S. Highways 34 and 65 at Lucas, U.S. Highway 65 south of Lucas, and all highways into Chariton were closed during the floods. At Lucas, 25 empty coal-rail cars were swept off the track and toppled onto their sides during the flooding. David Lundquist, Lucas County ASCS Director, reported 3,000 to 4,000 acres of cropland were inundated, or about six percent of the 67,000 acres of corn and soybeans in the county.

In Union County, floodwaters caused a dam to be breached at Little Lake near Thayer. Curt Greenfield, Union County Engineer, reported that the eastern onethird of the county was "basically devastated" by the floods, one bridge was destroyed and 19 other bridges were severely damaged. Paul Goldsmith, Union County District Conservationist, U.S. Soil Conservation Service, reported the flooding inundated 10,000 to 15,000 acres of land along streams and the Thompson River in Union County.

In Wayne County, U.S. Highway 65 south of State Highway 2, State Highway 14 north of Corydon, and State Highway 2 east of Corydon were closed during the floods. Vernon Brown, Wayne County Chief Deputy Sheriff, reported that every major highway in Wayne County was closed at some time during September 15th. On the afternoon of September 15th, flooded roads blocked access to Corydon for several hours. Mike Olson, Wayne County Engineer, reported that at least one bridge and six large culverts were destroyed by the floods, and that an estimated $\$ 300,000$ or more of gravel was washed-off of county roads. Don Bethards, Wayne County Assistant Engineer, reported that about one half of the roads in Wayne County lost surfacing and that damage from the floods was the worst he had seen in his 20 years on the job. Officials in Wayne County estimated that damage to bridges and roads was at least $\$ 1$ million. Jerry Taylor, Wayne County ASCS Director, reported that about 500 farm terraces were damaged in the county, soil erosion affected about 50,000 acres, and an estimated 25,000 acres of corn and soybeans were inundated, or about 12.5 percent of the 200,000 acres of cropland in the county. 
Significant flooding also occurred in portions of the Middle River, South River, White Breast Creek, English Creek, and Cedar Creek Basins (not shown, located north of the Thompson and Chariton River Basins), and in portions of the East Nodaway River and Platte River Basins (not shown, located west of the Thompson River Basin) (Gorman and others, 1993, p. 6-8; U.S. Department of Commerce, National Oceanic and Atmospheric Administration, and National Weather Service, 1992, Storm Summary Report, p. 5). As a result of the flooding, the following nine counties were declared Federal disaster areas: Adams (not shown, located west of Union County), Clarke, Decatur, Lucas, Madison, Monroe, Ringgold, Union, and Wayne. Flood damage eligible under the Public Assistance Program of the Federal Emergency Management Agency for the floods of September 15-16, 1992, that does not include residential and agricultural damage, exceeded \$2.1 million for the 5-county area of Clarke, Decatur, Lucas, Union, and Wayne Counties (information provided by Jerry Ostendorf, Iowa Emergency Management Division, written commun., December 1996).

A notable feature of the September 15-16, 1992, floods in south-central Iowa is the magnitude of runoff caused by the thunderstorms. Peak unit runoffs (discharge per square mile) (table 2) exceed the majority of those recorded for the 1993 floods (discussed in the next section), for drainage basins of size similar to the Thompson, Weldon, Chariton, and South Fork Chariton River Basins (104 to $701 \mathrm{mi}^{2}$ ) and are among the largest peak unit runoffs recorded in the flood history of the State. The flood of September 15-16, 1992, is the largest peak discharge and second highest peak stage at the Thompson River at Davis City gaging station during 1885-1995. The peak discharge and stage for the 1992 flood are both the largest known at the Weldon River near Leon gaging station during 1919-92, at the Chariton River near Chariton gaging station during 1947-95, and at the South Fork Chariton River near Promise City gaging station during 1965-95. At the Thompson River at Davis City gaging station, the September 16, 1992, flood-peak discharge of $57,000 \mathrm{ft}^{3} / \mathrm{s}$ is 1.7 times larger than the Bulletin $17 \mathrm{~B}$, 100-year recurrence-interval discharge (table 2) and the peak stage of $24.29 \mathrm{ft}$ exceeded the flood stage at this site by about $15.3 \mathrm{ft}$. At the Weldon River near Leon gaging station, the September 15,1992 , floodpeak discharge of $76,200 \mathrm{ft}^{3} / \mathrm{s}$ is 2.6 times larger than the Bulletin 17B, 100-year recurrence-interval dis- charge (table 2). At the Chariton River near Chariton gaging station, the September 15, 1992, flood-peak discharge of $37,700 \mathrm{ft}^{3} / \mathrm{s}$ is 1.4 times larger than the Bulletin 17B, 100-year recurrence-interval discharge (table 2) and the peak stage of $29.32 \mathrm{ft}$ exceeded the flood stage at this site by about $14.3 \mathrm{ft}$. At the South Fork Chariton River near Promise City gaging station, the September 15, 1992, flood-peak discharge of $70,600 \mathrm{ft}^{3} / \mathrm{s}$ is 2.1 times larger than the Bulletin 17B, 100-year recurrence-interval discharge (table 2) and the peak stage of $34.84 \mathrm{ft}$ exceeded the flood stage at this site by about $16.8 \mathrm{ft}$.

\section{Floods of July 5, 1993}

From mid-June through early August 1993, severe flooding in a nine-state area of the upper Mississippi River Basin followed an extended period of persistent precipitation that began in January. Flood-peak discharges that equalled or exceeded the 10 -year recurrence interval were recorded at 154 streamflow-gaging stations in the flooded region during June through August 1993 (Parrett and others, 1993). The month of July 1993 was the wettest July in Iowa in 121 years of record and also was the wettest month ever recorded in the State during 1873-1993 (Harry Hillaker, State Climatologist, Iowa Department of Agriculture and Land Stewardship, written commun., September, 1993). The floods of July 5, 1993, in south-central Iowa occurred as a result of intense thunderstorms over the area during July 4-5, 1993. Official rainfall amounts recorded during July 4-6, 1993, are listed in the table below (U.S. Department of Commerce, National Oceanic and Atmospheric Administration, and Iowa Department of Agriculture and Land Stewardship, 1993, p. 8).

\begin{tabular}{llll}
\hline \multicolumn{4}{c}{ Rain gage and rainfall for July 4-6, 1993, in Inches } \\
\hline Beaconsfield & 6.28 & Leon & 6.82 \\
Chariton & 7.63 & Lorimor & 4.10 \\
Creston & 2.32 & Osceola & 6.79 \\
Greenfield & 1.21 & Rathbun Dam & 4.69 \\
Lamoni & 6.22 & & \\
\hline
\end{tabular}

Floodwaters from the Chariton River flowed over the emergency spillway at Rathbun Dam for the first time since operation of the dam began in 1969. As a result of the floods of 1993, all 99 counties in Iowa 
were declared Federal disaster areas. Flood damage eligible under the Public Assistance Program of the Federal Emergency Management Agency for flooding that occurred from April 13 to October 1, 1993, that does not include residential and agricultural damage, exceeded $\$ 1.9$ million for the 6-county area of Adair, Clarke, Decatur, Lucas, Union, and Wayne Counties (information provided by Jerry Ostendorf, Iowa Emergency Management Division, written commun., December 1996).

At the Elk Creek near Decatur City streamflowgaging station, the peak discharge $\left(32,800 \mathrm{ft}^{3} / \mathrm{s}\right)$ for the flood of July 5, 1993 (table 2), is the largest recorded discharge at this site during 1959-95. The peak discharge of $32,800 \mathrm{ft}^{3} / \mathrm{s}$ is 1.1 times larger than the Bulletin 17B, 100-year recurrence-interval discharge (table 2). Based on information provided by the Decatur County Assistant Engineer, the stage of the 1959 flood at the Elk Creek gage exceeded the stage of the 1993 flood; a discharge was not determined for the 1959 flood at this site (table 2). At the Thompson River at Davis City gaging station, the peak discharge $\left(30,300 \mathrm{ft}^{3} / \mathrm{s}\right)$ for the flood of July 5,1993 , is the second largest recorded discharge at this site during 1885-1995 (table 2). The peak discharge of $30,300 \mathrm{ft}^{3} / \mathrm{s}$ has a recurrence interval of approximately 70 years (table 2 ). Discharges were not determined for five floods that occurred prior to operation of the Davis City gage (gage operation began May 1918) for which peak stages were reported to be higher than the peak stage of $20.53 \mathrm{ft}$ recorded for the 1993 flood (see Appendix A).

\section{PROFILES FOR THE FLOODS OF SEPTEMBER 15-16, 1992, IN THE THOMPSON, WELDON, AND CHARITON RIVER BASINS, SOUTH-CENTRAL IOWA}

Water-surface-elevation profiles for the floods of September 15-16, 1992, in the Thompson and Weldon River Basins in Iowa, and in the Chariton River Basin upstream of Rathbun Dam, are shown in Appendix B (figs. 4-10). Profiles for the floods of July 4, 1981, in the Chariton River Basin upstream of Rathbun Dam also are shown in Appendix B (figs. 8-10) for comparative purposes. The flood profiles were determined from high-water marks generally located immediately downstream and 1 bridge-length upstream from selected bridges. The high-water marks were identified within a few days of passage of the flood peak and were later referenced to sea level by differential leveling. Low-water profiles measured on August 2-3, 1995, in the Thompson, Weldon, and Chariton River Basins, and on July 18, 1984, in the Chariton River Basin, also are shown in figures 4-10 to indicate the approximate low-end of the range of stages that can occur within the profiled reaches.

The profiles were defined using data obtained by the USGS. The profiles between the measured watersurface elevations are represented by straight lines and are therefore only approximations of the actual watersurface elevations between the measurements. Watersurface elevations for ungaged bridge sites used in the 1992 flood profiles were collected at selected primary highway and paved county road bridges (figs. 1 and 410). The majority of the bridge sites used in the profiles were located between 10 and 15 river miles apart. Flood elevations were not collected at both the upstream and downstream sides of all bridges. Watersurface elevations for the 1981 floods were collected at every bridge along the profiled reaches of the Chariton and South Fork Chariton Rivers. Bridges along the Chariton and South Fork Chariton Rivers for which flood elevations were collected in 1981 but were not collected in 1992 are noted on the profiles in figures 9 and 10.

All river miles used in the profiles (figs. 4-10) were measured from the most current 1:24,000-scale USGS topographic maps. River miles measured for the Thompson and Weldon Rivers were referenced to the Iowa-Missouri State line, river miles measured for the Chariton and South Fork Chariton Rivers were referenced to Rathbun Dam, and river miles measured for Elk Creek were referenced to the mouth of Elk Creek. River miles were measured using a geographic information system, except along the Chariton River downstream of State Highway 14 and along the South Fork Chariton River which were measured manually from topographic maps for the 1981 flood profiles (Heinitz, 1986, p. 38-40). Measurements of river miles using larger- or smaller-scale cartographic data or different measurement methods may yield different values than those contained in this report. Bridges are designated by an index number derived from their respective locations using Public Land Survey System coordinates (township, range, section). For example, 6726-13 NE refers to a location in Township 67 North, Range 26 West, northeast quarter of section 13. 
A bench mark and a reference point were established at the majority of the bridges in the profiled reaches to reference all the points along the profiles to a common datum. Bench-mark and reference-point descriptions and elevations for bridge sites used in the September 15-16, 1992, flood profiles are listed in Appendix C.

Bridge-deck and low-bridge-chord elevations are shown in figures 4-10 to indicate the relation of the bridge to the high- and low-water surfaces. For sloping bridges, the bridge-deck and low-bridge-chord elevations represent the lower end of each bridge.

\section{CONSIDERATIONS}

The user of this report is cautioned that the stagedischarge data presented herein are representative of the physical conditions of the basin at the time of the floods described. Changes in the basin can alter the flood magnitude for a specific frequency. Examples of these basin changes include, but are not limited to, extensive urbanization, implementation of agricultural conservation practices, and installation of drainage systems. Changes in the channel conditions immediately downstream from a streamflow-gaging station can substantially affect the stage-discharge relation. Examples of such changes include the construction of dams, bridges, or levees; changes in the flood-plain vegetative cover; straightening of the channel; and natural scour and fill. Temporary changes can be caused by ice and debris jams that produce backwater conditions that cause water-surface elevations to be higher than would occur in an unobstructed channel.

\section{SUMMARY}

This report provides information on the floods of September 15-16, 1992, in the Thompson, Weldon, and Chariton River Basins in south-central Iowa. Information on the floods of July 4, 1981, on the Chariton and South Fork Chariton Rivers is included for comparative purposes. The September 15-16, 1992, floods are the largest known peak discharges at gaging stations Thompson River at Davis City (station number 06898000) $57,000 \mathrm{ft}^{3} / \mathrm{s}$, Weldon River near Leon (station number 06898400) 76,200 $\mathrm{ft}^{3} / \mathrm{s}$, Chariton River near Chariton (station number 06903400) $37,700 \mathrm{ft}^{3} / \mathrm{s}$, and South Fork Chariton River near
Promise City (station number 06903700 ) $70,600 \mathrm{ft}^{3} / \mathrm{s}$. The peak discharges were, respectively, 1.7, 2.6, 1.4, and 2.1 times larger than calculated 100-year recurrence-interval discharges. The report provides information on flood stages and discharges and floodflow frequencies for streamflow-gaging stations in the Thompson, Weldon, and Chariton River Basins using flood information collected through 1995. Information on temporary bench marks and reference points established in the Thompson and Weldon River Basins during 1994-95, and in the Chariton River Basin during 1983-84 and 1994-95, also is included in the report. A flood history summarizes rainfall conditions and damages for floods that occurred during 1947, 1959, 1981, 1992, and 1993.

\section{REFERENCES}

Cagle, J.W., and Heinitz, A.J., 1978, Water resources of south-central Iowa: Iowa Geological Survey Water Atlas No. 5, 97 p.

Des Moines Register, 1981, July 5 and 7, newspaper articles. 1992, September 16, 17, and 19, newspaper articles.

Eash, D.A., 1993, Estimating design-flood discharges for streams in Iowa using drainage-basin and channelgeometry characteristics: U.S. Geological Survey Water-Resources Investigation Report 93-4062, 96 p.

Fischer, E.E., 1993, Scour at a bridge over the Weldon River, Iowa, in Shen, H.W., Su, S.T., and Wen, Feng, eds., Proceedings of the Conference on Hydraulic Engineering 1993, San Francisco, California, July 25-30, 1993: New York, New York, American Society of Civil Engineers, v. 2, p. 1854-1859.

1995, Contraction scour at a bridge over Wolf Creek, Iowa, in Espey, W.H., Jr., and Combs, P.G., eds., Proceedings of the First International Conference on Water Resources Engineering 1995, San Antonio, Texas, August 14-18, 1995: New York, New York, American Society of Civil Engineers, v. 1, p. 430-434.

Gorman, J.G., Anderson, C.J., Lambert, R.B., Sneck-Fahrer, D.A., and Wang, W., 1993, Water resources data, Iowa, water year 1992: U.S. Geological Survey Water-Data Report IA-92-1, 374 p.

Heinitz, A.J., 1986, Floods in south-central Iowa: U.S. Geological Survey Open-File Report 85-100, 95 p.

Hillaker, H.H., 1992, Rainfall totals for 60 hours ending 7 a.m. CDT September 16, 1992: Des Moines, Iowa, Iowa Department of Agriculture and Land Stewardship, Iowa Climate Review, v 6, no. 9, p. 3. 
Interagency Advisory Committee on Water Data, 1982, Guidelines for determining flood flow frequency: Hydrology Subcommittee Bulletin 17B, U.S. Geological Survey, Office of Water Data Coordination, $28 \mathrm{p}$. and appendices.

Iowa Natural Resources Council, 1958, An inventory of water resources and water problems, southern Iowa river basins: Des Moines, Iowa, Iowa Natural Resources Council Bulletin no. 6, 70 p.

Lara, O.G., 1987, Method for estimating the magnitude and frequency of floods at ungaged sites on unregulated rural streams in Iowa: U.S. Geological Survey WaterResources Investigation Report 87-4132, 34 p.

Larimer, O.J., 1957, Drainage areas of Iowa streams: Iowa Highway Research Board Bulletin No. 7 (reprinted 1974), 439 p.

May, J.E., Gorman, J.G., Goodrich, R.D., Bobier, M.W., and Miller, V.E., 1996, Water resources data, Iowa, water year 1995: U.S. Geological Survey Water-Data Report IA-95-1, $390 \mathrm{p}$.

Novak, C.E., 1985, WRD data reports preparation guide: Reston, Virginia, U.S. Geological Survey, 199 p.

O'Connell, D.J., Lambert, R.B., Matthes, W.J., and SneckFahrer, D.A., 1992, Water resources data, Iowa, water year 1991: U.S. Geological Survey Water-Data Report IA-91-1, 385 p.

Oschwald, W.R., Riecken, F.F., Dideriksen, R.I., Scholtes, W.H., and Schaller, F.W., 1965, Principal soils of Iowa: Ames, Iowa, Iowa State University, Department of Agronomy, Special Report no. 42, 77 p.

Owenby, J.R., and Ezell, D.S., 1992, Monthly station normals of temperature, precipitation, and heating and cooling degree days 1961-1990, Iowa: Asheville, N.C., National Climatic Data Center, National Oceanic and Atmospheric Administration, Climatography of the United States no. 81, 32 p.

Parrett, Charles, Melcher, N.B., and James, R.W., 1993, Flood discharges in the upper Mississippi River Basin, 1993: U.S. Geological Survey Circular 1120-A, 14 p.

Prior, J.C., 1991, Landforms of Iowa: Iowa City, Iowa, Iowa Department of Natural Resources, University of Iowa Press, $153 \mathrm{p}$.

Rantz, S.E., and others, 1982, Measurement and computation of streamflow--Volume 2. Computation of discharge: U.S. Geological Survey Water-Supply Paper 2175, p. 285-631.

Schwob, H.H., 1953, Iowa floods--Magnitude and frequency: Iowa Highway Research Board Bulletin No. 1, $174 \mathrm{p}$.
U.S. Department of Commerce, National Oceanic and Atmospheric Administration, and Iowa Department of Agriculture and Land Stewardship, 1992, Climatological data, Iowa: Asheville, N.C., monthly summaries, v. 103 , no. 9,36 p.

1993, Climatological data, Iowa: Asheville, N.C., monthly summaries, v. 104, no. 7, 40 p.

U.S. Department of Commerce, National Oceanic and Atmospheric Administration, and Iowa Weather Service, 1981, Climatological data, Iowa: Asheville, N.C., monthly summaries, v. 92, no. 7, 36 p.

U.S. Department of Commerce, National Oceanic and Atmospheric Administration, and National Weather Service, 1992, Storm summary report, Iowa, September 1992: National Weather Service, WS Form F-2, 6 p.

U.S. Department of Commerce, Weather Bureau, and Iowa Department of Agriculture, 1947, Climatological data, Iowa: Des Moines, Iowa, monthly summaries, v. 58, no. 6, p. 66-72.

1959, Climatological data, Iowa: Des Moines, Iowa, monthly summaries, v. 70, no. 8, p. 121-136.

U.S. Geological Survey, 1919-96, Water resources data, Iowa, water years 1918-95 (published annually): U.S. Geological Survey Water-Data Reports. 


\section{APPENDIX A}

\section{PEAK STAGES AND DISCHARGES FOR STREAMFLOW-GAGING STATIONS IN THE THOMPSON, WELDON, AND CHARITON RIVER BASINS, SOUTH-CENTRAL IOWA}

The peak-stage and discharge data for streamflowgaging stations located in the Thompson, Weldon, and Chariton River Basins were compiled through September 30, 1995. The data are listed in chronological order. In general, independent peak discharges above a pre-selected base (partialduration series) are listed for the continuous-record gaging stations. The magnitude of the selected base discharge, given in the "Remarks" section of the headnote, was determined so that it would be equaled or exceeded on the average about three times per year. Two peak discharges are considered independent if a plot of the recorded stages indicates a welldefined trough between the peaks and if the instantaneous discharge of the trough is 25 percent or more below that of the lower peak (Novak, 1985, p. 93). Only annual peak discharges are listed for the crest-stage gaging stations.
The peak flow lists for each gaging-station are arranged in downstream order as explained in the annual water-data reports of the USGS (see "References"). The gaging stations are identified by a permanent number that also is used in figure 1 and in tables 1 and 2 of this report. The datum of the gage, when given, is above sea level. Flood stage as determined by the National Weather Service, when given, is the stage at which overflow of the natural banks of the stream begins to cause damage in the reach in which the elevation is measured.

Footnotes used throughout this appendix are selected so that each letter has the same meaning. For example, each occurrence of footnote " $\mathrm{e}$ " in any of the lists means “Affected by ice." Not all footnotes may appear in every list. 
20 


\section{Sevenmile Creek near Thayer}

Location.--Lat $41^{\circ} 01^{\prime} 37^{\prime \prime}$, long 9400'03”, in SE1/4, sec. 18, T.72 N., R.27 W., Clarke County, Hydrologic Unit 10280102, at culvert on U.S. Highway 34, 2.6 mi east of Thayer.

Drainage area.--6.61 $\mathrm{mi}^{2}$.

Gage.--Crest-stage gage.

Stage-discharge relation.--Defined by current-meter measurements and theoretical culvert rating.

Remarks.--Only annual peaks are shown.

\section{Peak stages and discharges}

[Water year, October 1-September 30 ; $\mathrm{ft}$, feet above gage datum; $\mathrm{ft}^{3} / \mathrm{s}$, cubic feet per second; --, not determined]

\begin{tabular}{clrr}
\hline Water year & Date & $\begin{array}{c}\text { Gage height } \\
\text { (ft) }\end{array}$ & $\begin{array}{c}\text { Discharge } \\
\left(\mathbf{f t}^{\mathbf{3}} / \mathbf{s}\right)\end{array}$ \\
\hline 1991 & June 15, 1991 & $\mathrm{a}_{2} 1.70$ & -- \\
1992 & Sept. 15, 1992 & 24.92 & $\mathrm{~b}_{1,330}$ \\
1993 & July 5, 1993 & 23.49 & $\mathrm{~b}_{1,220}$ \\
1994 & Mar. 1, 1994 & 15.57 & -- \\
1995 & May 23, 1995 & 15.08 & $\mathrm{~b}_{100}$ \\
\hline
\end{tabular}

${ }^{a}$ Gage height revised from previously published value.

${ }^{\mathrm{b}}$ Approximate. 


\section{Elk Creek near Decatur City, Iowa}

(Hydrologic bench mark station discontinued September 1, 1994)

Location.--Lat 4043'18", long 93'56' 12", in SE 1/4 sec. 34, T.69 N., R.27 W., Decatur County, Hydrologic Unit 10280102, at bridge on County Road R18, 1,000 ft downstream from West Elk Creek, 5.8 mi upstream from mouth, and $5.5 \mathrm{mi}$ west of Decatur City.

Drainage area.--52.5 $\mathrm{mi}^{2}$.

Gage.--Crest-stage gage. Datum of gage is $924.70 \mathrm{ft}$ above sea level. Oct. 1, 1967, to Sept. 1, 1994, operated as a continuous-record gage, and Oct. 1, 1967, to Sept. 30, 1974, at datum $10.00 \mathrm{ft}$ higher.

Stage-discharge relation.--Defined by current-meter and indirect measurements.

Remarks.--Base for partial-duration series, $500 \mathrm{ft}^{3} / \mathrm{s}$.

\section{Peak stages and discharges}

[Water year, October 1-September 30; ft, feet above gage datum; $\mathrm{ft}^{3} / \mathrm{s}$, cubic feet per second; --, not determined]

\begin{tabular}{|c|c|c|c|}
\hline Water year & Date & $\begin{array}{l}\text { Gage height } \\
\text { (ft) }\end{array}$ & $\begin{array}{c}\text { Discharge } \\
\left(\mathrm{ft}^{3} / \mathrm{s}\right)\end{array}$ \\
\hline 1959 & Aug. 6,1959 & $\mathrm{c}_{20.5}$ to 22.5 & -- \\
\hline \multirow[t]{2}{*}{1967} & June 14,1967 & $\mathrm{c}_{18.35}$ & $\mathrm{~d}_{17,800}$ \\
\hline & \multicolumn{3}{|c|}{ (Systematic operation of gage began October $1,1967)}$. \\
\hline \multirow[t]{3}{*}{1968} & Apr. 23,1968 & 10.50 & 2,900 \\
\hline & July 23,1968 & 8.14 & 1,540 \\
\hline & Aug. 4,1968 & 9.75 & 2,450 \\
\hline \multirow[t]{10}{*}{1969} & Apr. $\quad 4,1969$ & 6.11 & 654 \\
\hline & Apr. 17,1969 & 7.55 & 1,300 \\
\hline & Apr. 26,1969 & 11.39 & 3,490 \\
\hline & May 7,1969 & 10.44 & 2,930 \\
\hline & May 21,1969 & 11.32 & 3,440 \\
\hline & June 12,1969 & 8.47 & 1,700 \\
\hline & June 28,1969 & 10.27 & 2,760 \\
\hline & June 30,1969 & 10.40 & 2,840 \\
\hline & July $\quad 9,1969$ & 15.23 & 7,710 \\
\hline & July 18,1969 & 8.69 & 1,820 \\
\hline \multirow[t]{6}{*}{1970} & Apr. 18,1970 & 8.98 & 1,990 \\
\hline & May 12,1970 & 13.59 & 5,310 \\
\hline & Aug. 3,1970 & 5.77 & 500 \\
\hline & Sept. 15,1970 & 6.72 & 848 \\
\hline & Sept. 17,1970 & 5.93 & 556 \\
\hline & Sept. 22,1970 & 6.79 & 876 \\
\hline \multirow[t]{6}{*}{1971} & Oct. $\quad 9,1970$ & 5.94 & 559 \\
\hline & Oct. 26,1970 & 6.49 & 756 \\
\hline & Nov. 9,1970 & 5.78 & 503 \\
\hline & Dec. 10,1970 & 6.49 & 756 \\
\hline & May 6,1971 & 6.10 & 636 \\
\hline & May 7,1971 & 6.56 & 784 \\
\hline
\end{tabular}


06897950 Elk Creek near Decatur City, Iowa

Peak stages and discharges--Continued

\begin{tabular}{|c|c|c|c|}
\hline Water year & Date & $\begin{array}{c}\text { Gage height } \\
\text { (ft) }\end{array}$ & $\begin{array}{c}\text { Discharge } \\
\left(\mathrm{ft}^{3} / \mathrm{s}\right)\end{array}$ \\
\hline \multirow[t]{6}{*}{1972} & May 7,1972 & 11.46 & 3,480 \\
\hline & May 12,1972 & 7.42 & 1,220 \\
\hline & June 17,1972 & 9.64 & 2,400 \\
\hline & July 19,1972 & 7.76 & 1,360 \\
\hline & July 26,1972 & 9.71 & 2,470 \\
\hline & Sept. 12,1972 & 15.41 & 8,130 \\
\hline \multirow[t]{9}{*}{1973} & Nov. 13,1972 & 6.21 & 654 \\
\hline & Dec. 29,1972 & -- & $b_{3,400}$ \\
\hline & Jan. 16,1973 & 10.07 & 2,640 \\
\hline & Feb. $\quad 1,1973$ & 13.25 & 4,920 \\
\hline & Apr. $\quad 1,1973$ & -- & $\mathrm{b}_{2,000}$ \\
\hline & Apr. 16,1973 & -- & $\mathrm{b}_{2,200}$ \\
\hline & May 7,1973 & -- & ${ }^{b} 700$ \\
\hline & Aug. 11,1973 & 8.46 & 1,700 \\
\hline & Sept. 26,1973 & 11.50 & 3,500 \\
\hline \multirow[t]{13}{*}{1974} & Oct. 11,1973 & 13.60 & 5,320 \\
\hline & Nov. 20,1973 & 7.49 & 1,220 \\
\hline & Dec. 4,1973 & 9.90 & 2,540 \\
\hline & Jan. 20,1974 & -- & $\mathrm{b}_{1,000}$ \\
\hline & Jan. 26,1974 & -- & $\mathrm{b}_{1,300}$ \\
\hline & Mar. 8,1974 & 6.05 & 598 \\
\hline & Mar. 10, 1974 & 7.91 & 1,420 \\
\hline & Mar. 13, 1974 & 10.77 & 3,060 \\
\hline & Mar. 25, 1974 & 9.65 & 2,390 \\
\hline & Apr. 21,1974 & 12.50 & 4,170 \\
\hline & May 30,1974 & 12.47 & 4,150 \\
\hline & June 9,1974 & -- & $\mathrm{b}_{4,600}$ \\
\hline & ctober $1,1974, \mathrm{~g}$ & site at new datu & \\
\hline \multirow[t]{7}{*}{1975} & Oct. 31,1974 & 15.14 & 675 \\
\hline & Mar. 16,1975 & -- & $b_{800}$ \\
\hline & Mar. 17,1975 & 15.77 & 832 \\
\hline & Mar. 27, 1975 & 14.76 & 582 \\
\hline & May 7,1975 & 16.39 & 1,010 \\
\hline & June 23,1975 & 14.98 & 635 \\
\hline & Sept. 11,1975 & 14.87 & 608 \\
\hline \multirow[t]{5}{*}{1976} & Mar. 6,1976 & -- & 1,000 \\
\hline & Mar. 29, 1976 & 16.68 & 1,400 \\
\hline & Apr. 18,1976 & 21.70 & 5,450 \\
\hline & Apr. 20,1976 & 19.51 & 3,340 \\
\hline & Apr. 24,1976 & 25.80 & 11,400 \\
\hline 1977 & Sept. 2,1977 & 13.60 & 320 \\
\hline
\end{tabular}


06897950 Elk Creek near Decatur City, Iowa

Peak stages and discharges--Continued

\begin{tabular}{|c|c|c|c|}
\hline Water year & Date & $\begin{array}{c}\text { Gage height } \\
\text { (ft) }\end{array}$ & $\begin{array}{c}\text { Discharge } \\
\left(\mathrm{ft}^{3} / \mathrm{s}\right)\end{array}$ \\
\hline \multirow[t]{10}{*}{1978} & Oct. 23,1977 & 17.98 & 1,960 \\
\hline & Oct. 31,1977 & 18.62 & 2,340 \\
\hline & Mar. 21,1978 & 15.78 & 1,110 \\
\hline & Apr. 10,1978 & 16.65 & 1,500 \\
\hline & Apr. 17,1978 & 21.67 & 5,530 \\
\hline & May 7,1978 & 22.45 & 6,460 \\
\hline & May 11,1978 & 17.50 & 2,010 \\
\hline & July 21,1978 & 20.37 & 4,200 \\
\hline & Sept. 18,1978 & 14.42 & 653 \\
\hline & Sept. 20,1978 & 25.73 & 11,100 \\
\hline \multirow[t]{6}{*}{1979} & Mar. 16,1979 & 14.59 & 677 \\
\hline & Mar. 18,1979 & 16.76 & 1,540 \\
\hline & Mar. 23, 1979 & 19.85 & 3,870 \\
\hline & Mar. 30,1979 & 16.17 & 1,420 \\
\hline & May 2,1979 & 15.30 & 1,060 \\
\hline & June 27,1979 & 15.83 & 1,130 \\
\hline \multirow[t]{6}{*}{1980} & Mar. 15,1980 & 15.23 & 892 \\
\hline & June 2,1980 & 28.22 & 16,400 \\
\hline & June $\quad 4,1980$ & 19.26 & 3,170 \\
\hline & Aug. 31, 1980 & 22.37 & 6,220 \\
\hline & Sept. 1,1980 & 16.79 & 1,560 \\
\hline & Sept. 5,1980 & 16.99 & 1,660 \\
\hline \multirow[t]{2}{*}{1981} & Apr. 12,1981 & 14.82 & 746 \\
\hline & Apr. 13,1981 & 19.61 & 3,450 \\
\hline \multirow[t]{11}{*}{1982} & Mar. 19,1982 & 26.06 & 12,600 \\
\hline & Apr. 16,1982 & 20.00 & 4,310 \\
\hline & May 6,1982 & 21.40 & 5,780 \\
\hline & May 14,1982 & 20.75 & 5,070 \\
\hline & May 17,1982 & 14.45 & 776 \\
\hline & May 21,1982 & 16.02 & 1,440 \\
\hline & May 29,1982 & 16.40 & 1,640 \\
\hline & June 8,1982 & 19.65 & 3,990 \\
\hline & June 15,1982 & 16.90 & 1,920 \\
\hline & June 25,1982 & 15.50 & 1,190 \\
\hline & July 6,1982 & 23.65 & 8,690 \\
\hline \multirow[t]{7}{*}{1983} & Dec. 24,1982 & 14.83 & 964 \\
\hline & Dec. 27,1982 & 21.08 & 5,420 \\
\hline & Apr. 2,1983 & 14.05 & 735 \\
\hline & May 6,1983 & 18.00 & 2,640 \\
\hline & May 27,1983 & 19.00 & 3,420 \\
\hline & June 3,1983 & 16.18 & 1,540 \\
\hline & June 29,1983 & 16.44 & 1,680 \\
\hline
\end{tabular}


06897950 Elk Creek near Decatur City, Iowa--Continued

Peak stages and discharges--Continued

\begin{tabular}{|c|c|c|c|}
\hline Water year & Date & $\begin{array}{c}\text { Gage height } \\
\text { (ft) }\end{array}$ & $\begin{array}{c}\text { Discharge } \\
\left(\mathrm{ft}^{3} / \mathrm{s}\right)\end{array}$ \\
\hline \multirow[t]{9}{*}{1984} & Nov. 27,1983 & 14.10 & 630 \\
\hline & Apr. 3,1984 & 14.85 & 922 \\
\hline & Apr. 22,1984 & 16.06 & 1,460 \\
\hline & Apr. 27,1984 & 14.84 & 918 \\
\hline & Apr. 29,1984 & 17.79 & 2,490 \\
\hline & May 19,1984 & 14.79 & 899 \\
\hline & May 22,1984 & 16.77 & 1,840 \\
\hline & June 8,1984 & 17.95 & 2,610 \\
\hline & June 9,1984 & 19.75 & 4,080 \\
\hline \multirow[t]{3}{*}{1985} & Feb. 21,1985 & $e_{--}$ & 550 \\
\hline & Mar. 3,1985 & 15.65 & 1,250 \\
\hline & Sept. 29,1985 & 16.23 & 1,550 \\
\hline \multirow[t]{13}{*}{1986} & Oct. $\quad 9,1985$ & 20.16 & 4,510 \\
\hline & Oct. 12,1985 & 14.37 & 762 \\
\hline & Nov. 18,1985 & 16.66 & 1,960 \\
\hline & Apr. 3,1986 & 18.99 & 3,410 \\
\hline & May 16,1986 & 20.02 & 4,330 \\
\hline & July 10,1986 & 14.06 & 664 \\
\hline & July 12,1986 & 16.20 & 1,560 \\
\hline & July 14,1986 & 14.15 & 692 \\
\hline & Aug. 13, 1986 & 24.40 & 9,800 \\
\hline & Sept. 19,1986 & 21.93 & 4,450 \\
\hline & Sept. 22, 1986 & 19.49 & 3,730 \\
\hline & Sept. 24,1986 & 14.23 & 664 \\
\hline & Sept. 30,1986 & 17.76 & 2,810 \\
\hline \multirow[t]{17}{*}{1987} & Oct. 11,1986 & 19.01 & 3,440 \\
\hline & Oct. 24,1986 & 15.18 & 1,470 \\
\hline & Oct. 25,1986 & 12.94 & 524 \\
\hline & Mar. 18, 1987 & 14.79 & 1,290 \\
\hline & Mar. 28,1987 & 13.48 & 731 \\
\hline & Apr. 14,1987 & 13.47 & 731 \\
\hline & May 3,1987 & 13.46 & 735 \\
\hline & May 29,1987 & 16.34 & 1,970 \\
\hline & July 7,1987 & 25.96 & 9,340 \\
\hline & July $\quad 8,1987$ & 16.88 & 2,250 \\
\hline & July $\quad 9,1987$ & 22.92 & 6,180 \\
\hline & July 10,1987 & 15.57 & 1,630 \\
\hline & July 12,1987 & 22.30 & 5,700 \\
\hline & Aug. $\quad 8,1987$ & 13.00 & 545 \\
\hline & Aug. 13, 1987 & 12.98 & 538 \\
\hline & Aug. 15,1987 & 19.59 & 3,810 \\
\hline & Aug. 26, 1987 & 18.42 & 3,090 \\
\hline \multirow[t]{2}{*}{1988} & Nov. 28,1987 & 13.08 & 593 \\
\hline & Dec. 19,1987 & $\mathrm{e}_{13.38}$ & -- \\
\hline
\end{tabular}


06897950 Elk Creek near Decatur City, Iowa--Continued

Peak stages and discharges--Continued

\begin{tabular}{|c|c|c|c|}
\hline Water year & Date & $\begin{array}{c}\text { Gage height } \\
\text { (ft) }\end{array}$ & $\begin{array}{c}\text { Discharge } \\
\left(\mathrm{ft}^{3} / \mathrm{s}\right)\end{array}$ \\
\hline \multirow[t]{2}{*}{1989} & Sept. $\quad 8,1989$ & 14.09 & 991 \\
\hline & Sept. $\quad 9,1989$ & 23.21 & 6,410 \\
\hline \multirow[t]{16}{*}{1990} & Mar. 14,1990 & 13.48 & 731 \\
\hline & Mar. 15,1990 & 14.24 & 1,060 \\
\hline & Apr. 27,1990 & 13.55 & 760 \\
\hline & May $\quad 4,1990$ & 14.23 & 1,050 \\
\hline & May 12,1990 & 14.97 & 1,380 \\
\hline & May 16,1990 & 13.63 & 792 \\
\hline & May 25,1990 & 25.85 & 10,200 \\
\hline & June 7,1990 & 18.00 & 2,890 \\
\hline & June 16,1990 & 14.61 & 1,110 \\
\hline & June 17,1990 & 18.24 & 3,030 \\
\hline & June 20,1990 & 13.46 & 573 \\
\hline & June 22,1990 & 14.92 & 1,300 \\
\hline & July 20,1990 & 28.19 & $\mathrm{f}_{18,000}$ \\
\hline & July 21,1990 & 14.12 & 853 \\
\hline & July 27,1990 & 13.79 & 704 \\
\hline & Aug. 19, 1990 & 13.76 & 691 \\
\hline \multirow[t]{12}{*}{1991} & Feb. $\quad 3,1991$ & $e_{--}$ & 820 \\
\hline & Mar. 1,1991 & 15.69 & 1,690 \\
\hline & Mar. 17,1991 & 15.40 & 1,580 \\
\hline & Mar. 27, 1991 & 13.98 & 825 \\
\hline & Apr. 13,1991 & 13.75 & 730 \\
\hline & Apr. 14,1991 & 19.88 & 4,070 \\
\hline & Apr. 18,1991 & 18.63 & 3,260 \\
\hline & Apr. 27,1991 & 18.60 & 3,250 \\
\hline & Apr. 29,1991 & 13.22 & 505 \\
\hline & May 5,1991 & 17.10 & 2,400 \\
\hline & May 30,1991 & 14.61 & 1,110 \\
\hline & June 15,1991 & 20.65 & 4,600 \\
\hline \multirow[t]{14}{*}{1992} & Feb. 17,1992 & 15.57 & 1,640 \\
\hline & Feb. 18,1992 & 14.43 & 1,000 \\
\hline & Mar. 18,1992 & 13.36 & 526 \\
\hline & Apr. 16,1992 & 20.00 & 4,140 \\
\hline & Apr. 18,1992 & 15.89 & 1,790 \\
\hline & Apr. 19,1992 & 14.74 & 1,180 \\
\hline & Apr. 20,1992 & 15.62 & 1,660 \\
\hline & July 16,1992 & 16.71 & 2,200 \\
\hline & July 25,1992 & 18.55 & 3,210 \\
\hline & July 30,1992 & 22.21 & 5,770 \\
\hline & Sept. 2,1992 & 21.35 & 5,110 \\
\hline & Sept. $\quad 5,1992$ & 18.31 & 3,070 \\
\hline & Sept. 15,1992 & 27.94 & 16,200 \\
\hline & Sept. 18, 1992 & 15.85 & 1,770 \\
\hline
\end{tabular}


06897950 Elk Creek near Decatur City, Iowa--Continued

Peak stages and discharges--Continued

\begin{tabular}{|c|c|c|c|}
\hline Water year & Date & $\begin{array}{l}\text { Gage height } \\
\text { (ft) }\end{array}$ & $\begin{array}{c}\text { Discharge } \\
\left(\mathrm{ft}^{3} / \mathrm{s}\right)\end{array}$ \\
\hline \multirow[t]{15}{*}{1993} & Feb. $\quad 1,1993$ & ${ }^{\mathrm{e}} 14.38$ & 710 \\
\hline & Dec. 13,1992 & 19.25 & 3,660 \\
\hline & Mar. 2, 1993 & $\mathrm{e}_{15.09}$ & 1,030 \\
\hline & Apr. $\quad 8,1993$ & 14.08 & 863 \\
\hline & May 7,1993 & 17.00 & 2,350 \\
\hline & May 23, 1993 & 15.36 & 1,560 \\
\hline & June 30,1993 & 28.27 & 18,400 \\
\hline & July $\quad 5,1993$ & 29.93 & 32,800 \\
\hline & July 11,1993 & 23.43 & 8,170 \\
\hline & July 13,1993 & 23.02 & 7,710 \\
\hline & July 20,1993 & 19.62 & 4,390 \\
\hline & July 22,1993 & 20.31 & 4,980 \\
\hline & July 24,1993 & 22.58 & 7,220 \\
\hline & Sept. 22, 1993 & 14.21 & 887 \\
\hline & Sept. 25,1993 & 15.48 & 1,620 \\
\hline \multirow[t]{4}{*}{1994} & June $\quad 2,1994$ & 20.19 & 4,880 \\
\hline & June 11,1994 & 13.60 & 621 \\
\hline & June 12,1994 & 14.14 & 854 \\
\hline & June 23,1994 & 14.38 & 973 \\
\hline
\end{tabular}

(Continuous-record gage discontinued September 1, 1994. Operation of crest-stage-gage began September 1, 1994.) 1995 June 24,1995 18.17 3,260

\footnotetext{
${ }^{\mathrm{b}}$ Approximate.

${ }^{\mathrm{c}}$ Datum in use prior to October 1, 1974. Flood stage information provided by Decatur County Assistant Engineer.

${ }^{\mathrm{d}}$ Estimated from rating curve extended above $5,300 \mathrm{ft}^{3} / \mathrm{s}$ on basis of step-backwater computation.

${ }^{\mathrm{e}}$ Affected by ice.

${ }^{\mathrm{f}}$ Discharge computed from indirect measurement.
} 


\section{Thompson River at Davis City, Iowa}

Location.--Lat 40³8'25", long 93'48'29", in SE1/4 SE1/4 sec. 35, T.68 N., R.26 W., Decatur County, Hydrologic Unit 10280102, on right bank $15 \mathrm{ft}$ downstream from bridge on U.S. Highway 69 at Davis City, $3.1 \mathrm{mi}$ upstream from Dickersons Branch, and $5.8 \mathrm{mi}$ upstream from Iowa-Missouri State line.

Drainage area.--701 $\mathrm{mi}^{2}$.

Gage.--Water-stage recorder. Datum of gage is $874.04 \mathrm{ft}$ above sea level. May 14, 1918, to July 2, 1925, July 14, 1941, to Feb. 24, 1942, nonrecording gage, and Feb. 25, 1942, to Feb. 8, 1967, water-stage recorder at same site at datum $2.00 \mathrm{ft}$ higher.

Stage-discharge relation.--Defined by current-meter measurements, prior to 1992 from rating curve extensions above 15,000 and $17,000 \mathrm{ft}^{3} / \mathrm{s}$ on basis of velocity-area study (see footnotes " $\mathrm{h}$ " and " $\mathrm{j}$ " at end of station list).

Flood-stage.-- $9 \mathrm{ft}$.

Remarks.--Base for partial-duration series, $4,500 \mathrm{ft}^{3} / \mathrm{s}$. Prior to October 1918 , published as "Grand River."

\section{Peak stages and discharges}

[Water year, October 1-September 30; $\mathrm{ft}$, feet above gage datum; $\mathrm{ft}^{3} / \mathrm{s}$, cubic feet per second; --, not determined]

\begin{tabular}{|c|c|c|c|}
\hline Water year & Date & $\begin{array}{c}\text { Gage height } \\
\text { (ft) }\end{array}$ & $\begin{array}{c}\text { Discharge } \\
\left(\mathrm{ft}^{3} / \mathrm{s}\right)\end{array}$ \\
\hline 1885 & Aug. 8,1885 & $\mathrm{~g}_{22.8}$ & $\mathrm{~h}_{30,000}$ \\
\hline 1897 & Apr. 24,1897 & $\mathrm{~g}_{21.7}$ & -- \\
\hline 1903 & Aug. 27, 1903 & $\mathrm{~g}_{21.0}$ & -- \\
\hline 1909 & July $\quad 6,1909$ & $\mathrm{~g}_{20.3}$ & -- \\
\hline 1914 & Aug. 16,1914 & $\mathrm{~g}_{20.2}$ & -- \\
\hline 1915 & Mar. 28, 1915 & $\mathrm{~g}_{19.6}$ & -- \\
\hline \multicolumn{4}{|c|}{ (Systematic operation of gage began May 14,1918 , using chain gage.) } \\
\hline 1918 & June 6,1918 & 14.7 & 5,660 \\
\hline \multirow[t]{5}{*}{1919} & Mar. 16, 1919 & 17.8 & 10,100 \\
\hline & Apr. 22,1919 & 14.6 & 5,580 \\
\hline & May 4,1919 & 17.8 & 10,100 \\
\hline & June 4,1919 & 18.8 & 12,500 \\
\hline & Sept. 30,1919 & 14.2 & 5,260 \\
\hline \multirow[t]{7}{*}{1920} & Nov. 11,1919 & 15.2 & 6,100 \\
\hline & Mar. 24,1920 & 16.9 & 8,350 \\
\hline & Mar. 26, 1920 & 16.0 & 7,000 \\
\hline & Apr. 2,1920 & 15.2 & 6,100 \\
\hline & Apr. 21,1920 & 16.4 & 7,600 \\
\hline & Apr. 27,1920 & 13.7 & 4,890 \\
\hline & May 13,1920 & 16.9 & 8,350 \\
\hline \multirow[t]{2}{*}{1921} & May 11,1921 & 14.5 & 5,500 \\
\hline & June $\quad 2,1921$ & 15.1 & 5,280 \\
\hline \multirow[t]{4}{*}{1922} & May 23,1922 & 15.0 & 5,200 \\
\hline & July 18,1922 & 19.9 & 13,200 \\
\hline & July 30,1922 & 15.5 & 5,600 \\
\hline & Sept. 1,1922 & 17.6 & 8,040 \\
\hline 1923 & Nov. 13,1922 & 17.4 & 7,760 \\
\hline
\end{tabular}




\section{Thompson River at Davis City, Iowa}

Peak stages and discharges--Continued

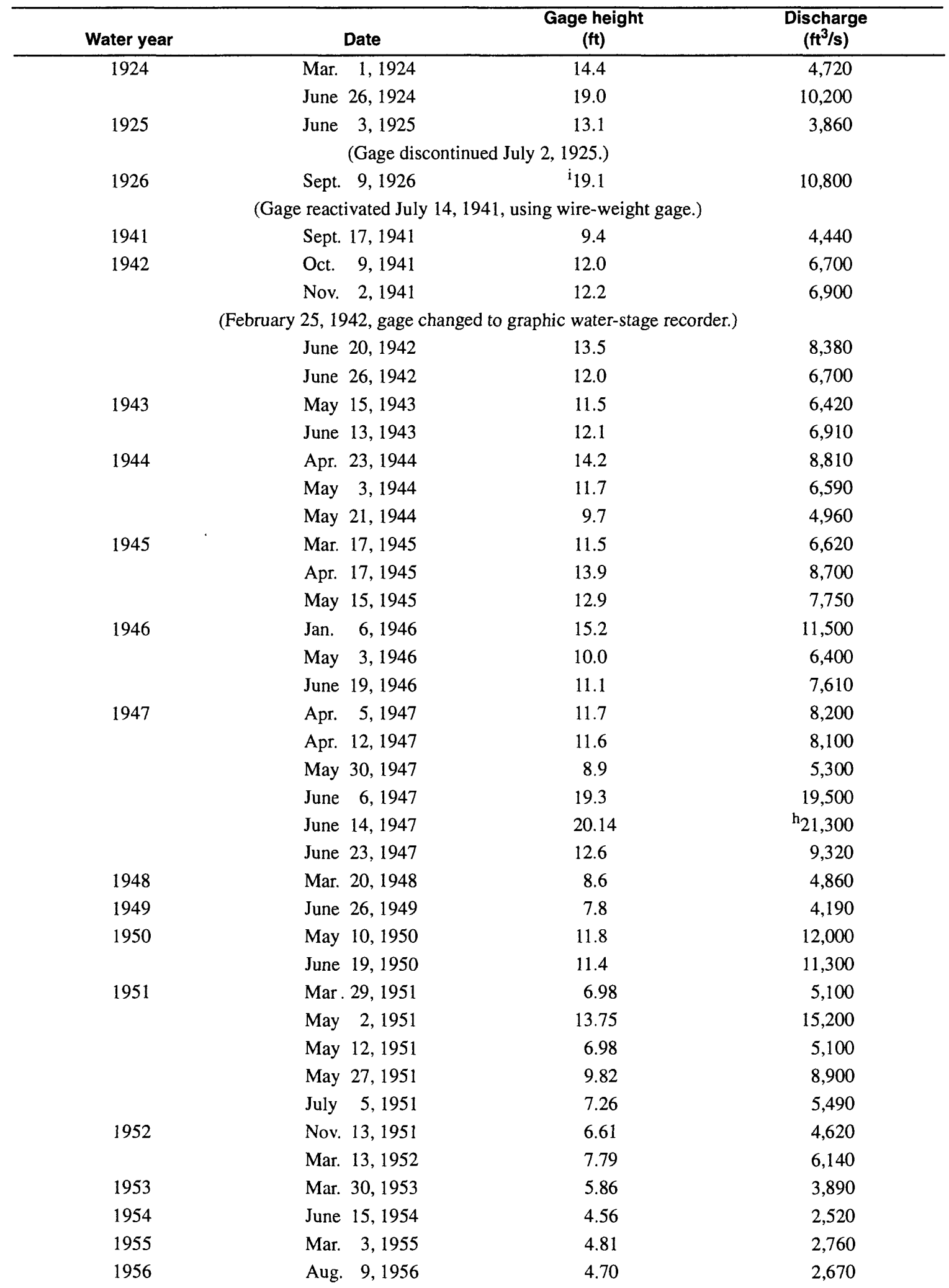




\section{Thompson River at Davis City, Iowa}

Peak stages and discharges--Continued

\begin{tabular}{|c|c|c|c|}
\hline Water year & Date & $\begin{array}{c}\text { Gage height } \\
\text { (ft) }\end{array}$ & $\begin{array}{c}\text { Discharge } \\
\left(\mathrm{ft}^{3} / \mathrm{s}\right)\end{array}$ \\
\hline 1957 & Apr. 3,1957 & 7.54 & 5,250 \\
\hline \multirow[t]{2}{*}{1958} & July 15,1958 & 9.22 & 7,400 \\
\hline & July 27,1958 & 8.19 & 5,850 \\
\hline \multirow[t]{7}{*}{1959} & Mar. 26, 1959 & 7.67 & 5,430 \\
\hline & Apr. 20,1959 & 9.18 & 6,900 \\
\hline & May 11,1959 & 10.25 & 7,900 \\
\hline & May 31,1959 & 10.60 & 8,300 \\
\hline & July $\quad 1,1959$ & 8.04 & 5,700 \\
\hline & Aug. $\quad 6,1959$ & 18.42 & 17,500 \\
\hline & Sept. 27,1959 & 10.35 & 8,100 \\
\hline \multirow[t]{4}{*}{1960} & Jan. 14,1960 & 11.92 & 9,690 \\
\hline & Mar. 30,1960 & 16.63 & 15,200 \\
\hline & Apr. 17,1960 & 6.97 & 4,800 \\
\hline & July $\quad 1,1960$ & 9.89 & 7,600 \\
\hline \multirow[t]{3}{*}{1961} & Feb. 18,1961 & $\mathrm{e}_{6.63}$ & $b_{4,600}$ \\
\hline & Mar. 14, 1961 & 6.78 & 5,230 \\
\hline & Sept. 13, 1961 & 8.22 & 6,820 \\
\hline \multirow[t]{5}{*}{1962} & Nov. 3,1961 & 6.61 & 5,050 \\
\hline & Nov. 16,1961 & 8.86 & 7,200 \\
\hline & Mar. 20, 1962 & 7.56 & 5,970 \\
\hline & May 31,1962 & 6.18 & 4,690 \\
\hline & June 10,1962 & 6.27 & 4,780 \\
\hline 1963 & Mar. 4,1963 & 6.00 & 4,510 \\
\hline \multirow[t]{3}{*}{1964} & June 21,1964 & 7.05 & 5,410 \\
\hline & Sept. $\quad 8,1964$ & 9.14 & 7,400 \\
\hline & Sept. 23, 1964 & 7.74 & 6,060 \\
\hline \multirow[t]{5}{*}{1965} & Mar. 17,1965 & 9.08 & 9,120 \\
\hline & Apr. $\quad 8,1965$ & 9.35 & 9,520 \\
\hline & May 8,1965 & 9.10 & 9,150 \\
\hline & July 1,1965 & 5.69 & 4,760 \\
\hline & Sept. 21,1965 & 8.87 & 8,820 \\
\hline \multirow[t]{3}{*}{1966} & May 17,1966 & 5.82 & 4,900 \\
\hline & June 13,1966 & 5.70 & 4,770 \\
\hline & July 28,1966 & 7.80 & 6,820 \\
\hline
\end{tabular}

(February 9, 1967, gage changed to digital water-stage recorder, at present site at new datum.)

$\begin{array}{rrrr}1967 & \text { June 14,1967 } & 11.96 & 10,400 \\ 1968 & \text { June 23, 1967 } & 11.65 & 9,980 \\ 1969 & \text { Apr. 23, 1968 } & 8.58 & 5,650 \\ & \text { Apr. 28, 1969 } & 7.87 & 4,830 \\ & \text { May 9,1969 } & 7.71 & 4,700 \\ & \text { June 13, } 1969 & 9.69 & 7,190 \\ & \text { July 9,1969 } & 12.01 & 10,500 \\ 1970 & \text { July 19,1969 } & 11.39 & 9,460 \\ & \text { May 14, 1970 } & 7.99 & 4,940\end{array}$


06898000 Thompson River at Davis City, Iowa

Peak stages and discharges--Continued

\begin{tabular}{|c|c|c|c|}
\hline Water year & Date & $\begin{array}{l}\text { Gage height } \\
\text { (ft) }\end{array}$ & $\begin{array}{c}\text { Discharge } \\
\left(\mathrm{ft}^{3} / \mathrm{s}\right)\end{array}$ \\
\hline 1971 & Feb. 20,1971 & ${ }^{\mathrm{e}} 8.40$ & $b_{5,200}$ \\
\hline \multirow[t]{3}{*}{1972} & May 7,1972 & 9.63 & 7,160 \\
\hline & Sept. 12,1972 & 10.82 & 8,470 \\
\hline & Sept. 16,1972 & 12.45 & 10,600 \\
\hline \multirow[t]{10}{*}{1973} & Dec. 30,1972 & 10.15 & 7,850 \\
\hline & Feb. $\quad 3,1973$ & 11.28 & 9,420 \\
\hline & Mar. 11,1973 & 8.29 & 5,510 \\
\hline & Mar. 14,1973 & 8.89 & 6,230 \\
\hline & Mar. 25, 1973 & 9.05 & 6,420 \\
\hline & Mar. 31,1973 & 11.27 & 9,400 \\
\hline & Apr. 16,1973 & 10.71 & 8,590 \\
\hline & May 2,1973 & 8.10 & 5,280 \\
\hline & May 8,1973 & 8.36 & 5,590 \\
\hline & Sept. 26,1973 & 9.21 & 6,610 \\
\hline \multirow[t]{4}{*}{1974} & Oct. 11,1973 & 14.21 & 14,200 \\
\hline & Apr. 21,1974 & 8.27 & 5,530 \\
\hline & May 30,1974 & 8.49 & 5,750 \\
\hline & June 10,1974 & 19.43 & $\mathrm{j}_{24,300}$ \\
\hline 1975 & Mar. 18,1975 & 7.38 & 4,420 \\
\hline \multirow[t]{3}{*}{1976} & Nov. 30,1975 & 8.09 & 5,270 \\
\hline & Apr. 20,1976 & 9.93 & 7,520 \\
\hline & Apr. 26,1976 & 13.26 & 12,500 \\
\hline 1977 & Sept. 3,1977 & 6.12 & 3,120 \\
\hline \multirow[t]{7}{*}{1978} & Oct. 24,1977 & 9.07 & 6,500 \\
\hline & Mar. 22, 1978 & 9.16 & 6,880 \\
\hline & Apr. 10,1978 & 7.61 & 5,020 \\
\hline & Apr. 19,1978 & 11.37 & 9,960 \\
\hline & May 7,1978 & 10.46 & 8,510 \\
\hline & July 22,1978 & 7.59 & 4,880 \\
\hline & Sept. 20,1978 & 11.68 & 10,200 \\
\hline \multirow[t]{2}{*}{1979} & Mar. 19, 1979 & 7.84 & 5,090 \\
\hline & Mar. 23, 1979 & 10.34 & 8,220 \\
\hline \multirow[t]{4}{*}{1980} & June 2,1980 & 12.94 & 12,400 \\
\hline & June 5,1980 & 8.99 & 6,610 \\
\hline & Aug. 31,1980 & 8.25 & 5,660 \\
\hline & Sept. $\quad 1,1980$ & 8.06 & 5,440 \\
\hline \multirow[t]{2}{*}{1981} & Apr. 14,1981 & 8.06 & 5,420 \\
\hline & July $\quad 5,1981$ & 7.99 & 5,340 \\
\hline \multirow[t]{6}{*}{1982} & Mar. 19,1982 & 11.84 & 10,600 \\
\hline & Apr. 17,1982 & 7.57 & 4,840 \\
\hline & May 6,1982 & 10.72 & 8,940 \\
\hline & May 15,1982 & 7.93 & 5,260 \\
\hline & May 22,1982 & 9.22 & 6,880 \\
\hline & July $\quad 7,1982$ & 7.34 & 4,580 \\
\hline
\end{tabular}




\section{Thompson River at Davis City, Iowa}

Peak stages and discharges--Continued

\begin{tabular}{|c|c|c|c|}
\hline Water year & Date & $\begin{array}{c}\text { Gage height } \\
\text { (ft) }\end{array}$ & $\begin{array}{c}\text { Discharge } \\
\left(\mathrm{ft}^{3} / \mathrm{s}\right)\end{array}$ \\
\hline \multirow[t]{4}{*}{1983} & Dec. 6,1982 & 7.47 & 4,720 \\
\hline & Dec. 28,1982 & 9.06 & 6,710 \\
\hline & Apr. $\quad 3,1983$ & 8.08 & 5,530 \\
\hline & May 27,1983 & 8.46 & 6,000 \\
\hline \multirow[t]{7}{*}{1984} & Apr. 22,1984 & 8.05 & 5,470 \\
\hline & Apr. 30,1984 & 8.15 & 5,590 \\
\hline & May 20,1984 & 7.57 & 4,910 \\
\hline & May 26,1984 & 7.50 & 4,830 \\
\hline & June 9,1984 & 9.23 & 6,950 \\
\hline & June 12,1984 & 7.27 & 4,570 \\
\hline & June 18,1984 & 7.98 & 5,390 \\
\hline \multirow[t]{2}{*}{1985} & Feb. 21,1985 & $\mathrm{e}_{7.43}$ & -- \\
\hline & Feb. 23,1985 & 6.66 & 4,020 \\
\hline \multirow[t]{7}{*}{1986} & Oct. $\quad 9,1985$ & 8.24 & 5,930 \\
\hline & Apr. $\quad 4,1986$ & 9.52 & 7,550 \\
\hline & May 1,1986 & 7.58 & 5,100 \\
\hline & May 17,1986 & 10.55 & 8,990 \\
\hline & Aug. 13,1986 & 9.78 & 7,910 \\
\hline & Sept. 19,1986 & 9.70 & 7,800 \\
\hline & Sept. 24,1986 & 8.35 & 6,030 \\
\hline \multirow[t]{9}{*}{1987} & Oct. 12,1986 & 7.50 & 5,250 \\
\hline & Apr. 15,1987 & 7.35 & 5,040 \\
\hline & June 1,1987 & 7.49 & 5,240 \\
\hline & July 7,1987 & 9.72 & 8,650 \\
\hline & July $\quad 8,1987$ & 9.55 & 8,380 \\
\hline & July $\quad 9,1987$ & 12.10 & 12,100 \\
\hline & July 12,1987 & 12.96 & 13,300 \\
\hline & Aug. 15,1987 & 7.42 & 5,140 \\
\hline & Aug. 28, 1987 & 13.81 & 14,600 \\
\hline \multirow[t]{2}{*}{1988} & Nov. 29,1987 & 5.37 & 2,640 \\
\hline & Feb. 20,1988 & $\mathrm{e}_{5.45}$ & -- \\
\hline 1989 & Sept. $\quad 9,1989$ & 9.76 & 8,720 \\
\hline \multirow[t]{5}{*}{1990} & Mar. 15,1990 & 7.08 & 4,680 \\
\hline & May 25,1990 & 11.70 & 13,600 \\
\hline & June 18,1990 & 12.55 & 12,700 \\
\hline & June 20,1990 & 7.32 & 5,000 \\
\hline & July 20,1990 & 13.30 & 13,800 \\
\hline \multirow[t]{5}{*}{1991} & Apr. 14,1991 & 9.50 & 8,310 \\
\hline & Apr. 19,1991 & 11.95 & 11,800 \\
\hline & Apr. 27,1991 & 8.34 & 6,480 \\
\hline & May 5,1991 & 8.93 & 7,400 \\
\hline & June 16,1991 & 8.25 & 6,340 \\
\hline
\end{tabular}




\section{Thompson River at Davis City, Iowa}

Peak stages and discharges--Continued

\begin{tabular}{|c|c|c|c|}
\hline Water year & Date & $\begin{array}{l}\text { Gage height } \\
\text { (ft) }\end{array}$ & $\begin{array}{c}\text { Discharge } \\
\left(\mathrm{ft}^{3} / \mathrm{s}\right)\end{array}$ \\
\hline \multirow[t]{5}{*}{1992} & Feb. 18,1992 & 7.66 & 5,360 \\
\hline & Apr. 21,1992 & 8.57 & 6,730 \\
\hline & July 30,1992 & 10.19 & 9,200 \\
\hline & Sept. 2,1992 & 8.94 & 7,280 \\
\hline & Sept. 16,1992 & 24.29 & 57,000 \\
\hline \multirow[t]{15}{*}{1993} & Nov. 21, 1992 & 9.28 & 8,040 \\
\hline & Dec. 14,1992 & 11.04 & 10,500 \\
\hline & Mar. $\quad 5,1993$ & 7.55 & 5,850 \\
\hline & Mar. 31, 1993 & 6.43 & 4,530 \\
\hline & May 8,1993 & 7.44 & 5,720 \\
\hline & June 20,1993 & 7.17 & 5,390 \\
\hline & July $\quad 1,1993$ & 13.33 & 13,800 \\
\hline & July $\quad 5,1993$ & 20.53 & 30,300 \\
\hline & July 10,1993 & 11.69 & 11,400 \\
\hline & July 11,1993 & 11.29 & 10,800 \\
\hline & July 13,1993 & 9.87 & 8,830 \\
\hline & July 22,1993 & 11.69 & 11,400 \\
\hline & July 24,1993 & 14.74 & 16,000 \\
\hline & Aug. 21,1993 & 11.32 & 10,900 \\
\hline & Sept. 26,1993 & 7.76 & 6,110 \\
\hline 1994 & June 2,1994 & 7.64 & 5,960 \\
\hline \multirow[t]{7}{*}{1995} & Apr. 11,1995 & 6.49 & 4,600 \\
\hline & Apr. 27,1995 & 6.59 & 4,720 \\
\hline & May 8,1995 & 8.29 & 6,770 \\
\hline & May 13,1995 & 10.16 & 9,230 \\
\hline & May 23, 1995 & 11.83 & 11,600 \\
\hline & May 28,1995 & 7.42 & 5,690 \\
\hline & July $\quad 5,1995$ & 6.61 & 4,740 \\
\hline
\end{tabular}

${ }^{\mathrm{b}}$ Approximate.

eAffected by ice.

${ }^{f}$ Discharge computed from indirect measurement.

${ }^{\mathrm{g}}$ High-water mark cut in the brickwork of a mill structure located about $1,000 \mathrm{ft}$ downstream of gage. Discharge for the 1885 flood was estimated; other historic flood discharges could not be estimated. Stage-discharge relation is subject to large shifts (Schwob, 1953, p. 168). Datum in use prior to February 9, 1967.

${ }^{\mathrm{h}}$ Discharge determined from rating curve extended above $15,000 \mathrm{ft}^{3} / \mathrm{s}$ on basis of velocity-area study.

${ }^{\mathrm{i}}$ Following discontinuance of gage July 2, 1925, a few gage-height reading were collected in 1926.

${ }^{\mathrm{j}}$ Discharge determined from rating curve extended above $17,000 \mathrm{ft}^{3} / \mathrm{s}$ on basis of velocity-area study. 


\section{Weldon River near Leon, Iowa}

(Discontinued September 30, 1991)

Location.--Lat $40^{\circ} 41^{\prime} 45^{\prime \prime}$, long 93'38'07", in NE1/4 NE1/4 sec. 17, T.68 N., R.24 W., Decatur County, Hydrologic Unit 10280102, on left bank $10 \mathrm{ft}$ downstream from bridge on County Road J46, $200 \mathrm{ft}$ upstream from Unnamed Creek, 1.3 mi downstream from Brush Creek, and $6.5 \mathrm{mi}$ southeast of post office at Leon.

Drainage area.--104 $\mathrm{mi}^{2}$.

Gage.--Water-stage recorder. Datum of gage is $906.26 \mathrm{ft}$ above sea level.

Stage-discharge relation.--Defined by current-meter measurements and above $5,600 \mathrm{ft}^{3} / \mathrm{s}$ by indirect measurements.

Remarks.--Base for partial-duration series, $4,500 \mathrm{ft}^{3} / \mathrm{s}$.

Peak stages and discharges

[Water year, October 1-September 30; ft, feet above gage datum; $\mathrm{ft}^{3} / \mathrm{s}$, cubic feet per second; --, not determined]

\begin{tabular}{|c|c|c|c|}
\hline Water year & Date & $\begin{array}{c}\text { Gage height } \\
\text { (ft) }\end{array}$ & $\begin{array}{c}\text { Discharge } \\
\left(\mathrm{ft}^{3} / \mathrm{s}\right)\end{array}$ \\
\hline \multirow[t]{6}{*}{1959} & Nov. 17,1958 & 17.87 & 7,410 \\
\hline & Apr. 20,1959 & 17.32 & 6,870 \\
\hline & May 21, 1959 & 19.16 & 8,740 \\
\hline & May 29,1959 & 16.74 & 6,330 \\
\hline & May 30,1959 & 15.37 & 5,220 \\
\hline & Aug. $\quad 6,1959$ & $\mathrm{k}_{25.27}$ & $\mathrm{f}, \mathrm{k}_{48,600}$ \\
\hline \multirow[t]{4}{*}{1960} & Oct. $\quad 5,1959$ & 16.00 & 5,700 \\
\hline & Mar. 29,1960 & 18.12 & 7,220 \\
\hline & Apr. 16,1960 & 19.72 & 9,210 \\
\hline & May 16,1960 & 15.88 & 4,910 \\
\hline \multirow[t]{5}{*}{1961} & Feb. 18,1961 & 16.00 & 5,000 \\
\hline & Mar. $\quad 5,1961$ & 19.85 & 8,020 \\
\hline & July 15,1961 & 21.62 & 10,000 \\
\hline & Sept. 13,1961 & 22.14 & 11,600 \\
\hline & Sept. 30,1961 & 15.91 & 4,930 \\
\hline \multirow[t]{4}{*}{1962} & Nov. 2,1961 & 15.62 & 4,720 \\
\hline & Nov. 16,1961 & 17.25 & 5,860 \\
\hline & May 29,1962 & 15.96 & 5,000 \\
\hline & June 10,1962 & 21.63 & 10,000 \\
\hline \multirow[t]{2}{*}{1963} & Mar. 4,1963 & $e_{13.95}$ & -- \\
\hline & Mar. 18, 1963 & 13.22 & 3,150 \\
\hline 1964 & Sept. $\quad 6,1964$ & 19.48 & 7,750 \\
\hline \multirow[t]{2}{*}{1965} & Apr. 8,1965 & 15.45 & 4,760 \\
\hline & Sept. 21,1965 & 19.10 & 7,570 \\
\hline 1966 & June 13,1966 & 10.65 & 1,840 \\
\hline \multirow[t]{2}{*}{1967} & June 12,1967 & 15.48 & 4,640 \\
\hline & June 14,1967 & 15.80 & 4,860 \\
\hline 1968 & Apr. 22,1968 & 20.12 & 8,310 \\
\hline 1969 & Apr. 26, 1969 & 17.97 & 6,480 \\
\hline \multirow[t]{2}{*}{1970} & May 14,1970 & 20.11 & 8,300 \\
\hline & Sept. 17,1970 & 15.63 & 4,740 \\
\hline
\end{tabular}


06898400 Weldon River near Leon, Iowa

Peak stages and discharges--Continued

\begin{tabular}{|c|c|c|c|}
\hline Water year & Date & $\begin{array}{c}\text { Gage height } \\
\text { (ft) }\end{array}$ & $\begin{array}{c}\text { Discharge } \\
\left(\mathrm{ft}^{3} / \mathrm{s}\right)\end{array}$ \\
\hline 1971 & Oct. $\quad 9,1970$ & 14.90 & 4,230 \\
\hline \multirow[t]{2}{*}{1972} & Sept. 12,1972 & 17.19 & 5,850 \\
\hline & Sept. 14,1972 & 17.20 & 5,980 \\
\hline \multirow[t]{3}{*}{1973} & Feb. $\quad 1,1973$ & 15.60 & 4,720 \\
\hline & Mar. 31, 1973 & 18.95 & 7,260 \\
\hline & Apr. 16,1973 & 16.54 & 5,480 \\
\hline \multirow[t]{4}{*}{1974} & Oct. 11,1973 & ${ }^{1} 21.45$ & 9,710 \\
\hline & Apr. 21,1974 & 15.61 & 4,770 \\
\hline & May 30,1974 & 16.65 & 5,460 \\
\hline & June 9,1974 & 17.30 & 6,100 \\
\hline 1975 & Apr. 23,1975 & 12.52 & 2,660 \\
\hline \multirow[t]{2}{*}{1976} & Apr. 18,1976 & 15.60 & 4,720 \\
\hline & Apr. 24,1976 & 16.70 & 5,490 \\
\hline 1977 & Aug. 9,1977 & 10.84 & 1,460 \\
\hline \multirow[t]{4}{*}{1978} & Oct. 24,1977 & 18.68 & 7,130 \\
\hline & Apr. 17,1978 & 15.89 & 4,990 \\
\hline & May 7,1978 & 16.88 & 5,690 \\
\hline & Sept. 20,1978 & 15.79 & 4,950 \\
\hline 1979 & Mar. 23, 1979 & 16.05 & 5,180 \\
\hline \multirow[t]{3}{*}{1980} & June 2,1980 & 21.61 & 10,000 \\
\hline & June 4,1980 & 18.80 & 7,140 \\
\hline & Sept. 1,1980 & 17.90 & 6,420 \\
\hline 1981 & July $\quad 4,1981$ & 20.17 & 8,700 \\
\hline \multirow[t]{2}{*}{1982} & Mar. 19,1982 & 19.37 & 7,990 \\
\hline & May 6,1982 & 17.63 & 6,600 \\
\hline 1983 & Oct. $\quad 9,1982$ & 14.37 & 4,060 \\
\hline 1984 & June $\quad 9,1984$ & 14.16 & 3,940 \\
\hline 1985 & Sept. 29,1985 & 12.28 & 2,840 \\
\hline 1986 & Sept. 19,1986 & 16.36 & 6,040 \\
\hline 1987 & Aug. 15,1987 & 17.09 & 6,020 \\
\hline 1988 & Nov. 28,1987 & 10.90 & 2,100 \\
\hline 1989 & Sept. 9,1989 & 18.45 & 7,130 \\
\hline \multirow[t]{2}{*}{1990} & May 25,1990 & 17.96 & 6,720 \\
\hline & July 20,1990 & 18.71 & 7,350 \\
\hline \multirow[t]{2}{*}{1991} & Apr. 18,1991 & 16.70 & 5,480 \\
\hline & \multicolumn{2}{|c|}{ (Gage discontinued September 30,1991.) } & \\
\hline 1992 & Sept. 15,1992 & $1, \mathrm{~m}_{28.69}$ & $\mathrm{n}_{76,200}$ \\
\hline
\end{tabular}

${ }^{\mathrm{b}}$ Approximate.

eAffected by ice.

${ }^{f}$ Discharge computed from indirect measurement.

${ }^{\mathrm{k}}$ Greatest since at least 1919.

'Gage height determined from floodmarks.

${ }^{\mathrm{m}}$ Gage height affected by backwater.

${ }^{\mathrm{n}}$ Discharge estimated by drainage-area ratio transfer of discharge computed from indirect measurement of September 15 , 1992, flood at State Highway 2 bridge crossing Weldon River. 


\section{Chariton River near Chariton, Iowa}

Location.--Lat 40 57' 12", long 93'15'37", in SW1/4 NE1/4 sec. 15, T.71 N., R.21 W., Lucas County, Hydrologic Unit 10280201, on right bank $15 \mathrm{ft}$ downstream from bridge on County Road S43, 0.4 mi downstream from Wolf Creek, and $5.0 \mathrm{mi}$ southeast of Chariton.

Drainage area.--182 $\mathrm{mi}^{2}$.

Gage.--Water-stage recorder. Datum of gage is $917.90 \mathrm{ft}$ above sea level (U.S. Army Corps of Engineers bench mark).

Stage-discharge relation.--Defined by current-meter and indirect measurements.

Flood stage.--15 ft.

Remarks.--Base for partial-duration series, $1,600 \mathrm{ft}^{3} / \mathrm{s}$. Prior to Oct. 1,1981 , base for partial-duration series was $1,200 \mathrm{ft}^{3} / \mathrm{s}$.

\section{Peak stages and discharges}

[Water year, October 1-September 30; $\mathrm{ft}$, feet above gage datum; $\mathrm{ft}^{3} / \mathrm{s}$, cubic feet per second; --, not determined]

\begin{tabular}{|c|c|c|c|}
\hline Water year & Date & $\begin{array}{c}\text { Gage height } \\
\text { (ft) }\end{array}$ & $\begin{array}{c}\text { Discharge } \\
\left(\mathrm{ft}^{3} / \mathrm{s}\right)\end{array}$ \\
\hline 1947 & June 5,1947 & 121.65 & 11,000 \\
\hline \multirow[t]{2}{*}{1960} & March 1960 & $\mathrm{~b}_{23.0}$ & $\mathrm{~b}_{15,000}$ \\
\hline & \multicolumn{3}{|c|}{ (Systematic operation of gage began October $1,1965$. ) } \\
\hline 1966 & Feb. 9,1966 & 15.90 & 1,360 \\
\hline \multirow[t]{3}{*}{1967} & June 10,1967 & 16.82 & 1,670 \\
\hline & June 14,1967 & 18.08 & 2,820 \\
\hline & June 21,1967 & 19.53 & 4,930 \\
\hline 1968 & Apr. 23,1968 & 19.90 & 5,660 \\
\hline \multirow[t]{4}{*}{1969} & Apr. 27,1969 & 16.26 & 1,360 \\
\hline & July 10,1969 & 16.21 & 1,340 \\
\hline & July 13,1969 & 16.77 & 1,640 \\
\hline & July 21,1969 & 16.32 & 1,390 \\
\hline \multirow[t]{4}{*}{1970} & Apr. 19,1970 & 16.61 & 1,550 \\
\hline & May 15,1970 & 17.44 & 2,120 \\
\hline & Aug. 8,1970 & 20.15 & 6,320 \\
\hline & Sept. 17,1970 & 18.29 & 3,230 \\
\hline \multirow[t]{2}{*}{1971} & Oct. $\quad 9,1970$ & 17.28 & 2,080 \\
\hline & Feb. 19, 1971 & $e_{17.60}$ & -- \\
\hline \multirow[t]{3}{*}{1972} & May 8,1972 & 16.32 & 1,390 \\
\hline & Sept. 13,1972 & 17.29 & 1,990 \\
\hline & Sept. 14,1972 & 18.08 & 2,820 \\
\hline
\end{tabular}




\section{Chariton River near Chariton, Iowa}

Peak stage and discharges--Continued

\begin{tabular}{|c|c|c|c|}
\hline Water year & Date & $\begin{array}{c}\text { Gage height } \\
\text { (ft) }\end{array}$ & $\begin{array}{c}\text { Discharge } \\
\left(\mathrm{ft}^{3} / \mathrm{s}\right)\end{array}$ \\
\hline \multirow[t]{14}{*}{1973} & Feb. $\quad 2,1973$ & 17.63 & 2,290 \\
\hline & Mar. 7,1973 & 16.20 & 1,330 \\
\hline & Mar. 11,1973 & 16.49 & 1,470 \\
\hline & Mar. 26, 1973 & 16.89 & 1,710 \\
\hline & Apr. $\quad 1,1973$ & 17.22 & 1,940 \\
\hline & Apr. 16,1973 & 18.02 & 2,740 \\
\hline & May 2,1973 & 17.01 & 1,790 \\
\hline & May 7,1973 & 16.44 & 1,470 \\
\hline & May 27,1973 & 17.30 & 2,080 \\
\hline & June 19,1973 & 17.58 & 2,240 \\
\hline & July 4,1973 & 16.12 & 1,290 \\
\hline & Aug. 12,1973 & 16.46 & 1,460 \\
\hline & Sept. 25,1973 & 16.81 & 1,670 \\
\hline & Sept. 28,1973 & 16.03 & 1,250 \\
\hline \multirow[t]{8}{*}{1974} & Oct. $\quad 3,1973$ & 15.98 & 1,230 \\
\hline & Oct. 12,1973 & 20.20 & 6,300 \\
\hline & Dec. 5,1973 & 15.95 & 1,220 \\
\hline & Jan. 27,1974 & 17.55 & 2,220 \\
\hline & Apr. 21,1974 & 16.85 & 1,750 \\
\hline & May 18,1974 & 16.03 & 1,250 \\
\hline & June 9,1974 & 17.89 & 2,590 \\
\hline & June 13,1974 & 16.82 & 1,770 \\
\hline \multirow[t]{2}{*}{1975} & Mar. 18,1975 & 16.27 & 1,360 \\
\hline & June 28,1975 & 16.82 & 1,670 \\
\hline \multirow[t]{3}{*}{1976} & Apr. 21,1976 & 17.17 & 1,430 \\
\hline & Apr. 25,1976 & 18.59 & 2,490 \\
\hline & June 14,1976 & 20.35 & 5,460 \\
\hline 1977 & Aug. 27, 1977 & 17.27 & 1,490 \\
\hline \multirow[t]{8}{*}{1978} & Oct. 24,1977 & 19.34 & 3,520 \\
\hline & Oct. 31,1977 & 17.28 & 1,500 \\
\hline & Mar. 22, 1978 & 17.48 & 1,300 \\
\hline & Apr. 10,1978 & 18.22 & 3,340 \\
\hline & Apr. 18,1978 & 17.66 & 1,730 \\
\hline & May 7,1978 & 17.51 & 1,830 \\
\hline & May 13,1978 & 17.43 & 1,770 \\
\hline & Sept. 21,1978 & 19.79 & 3,660 \\
\hline \multirow[t]{3}{*}{1979} & Mar. 4,1979 & ${ }^{\mathrm{e}} 18.24$ & 1,600 \\
\hline & Mar. 24, 1979 & 17.75 & 1,890 \\
\hline & May 3,1979 & 17.09 & 1,540 \\
\hline \multirow[t]{3}{*}{1980} & June 2,1980 & 20.84 & 7,000 \\
\hline & June $\quad 4,1980$ & 20.31 & 5,380 \\
\hline & Sept. $\quad 1,1980$ & 16.70 & 1,210 \\
\hline
\end{tabular}


06903400 Chariton River near Chariton, Iowa

Peak stage and discharges--Continued

\begin{tabular}{|c|c|c|c|}
\hline Water year & Date & $\begin{array}{c}\text { Gage height } \\
\text { (ft) }\end{array}$ & $\begin{array}{c}\text { Discharge } \\
\left(\mathrm{ft}^{3} / \mathrm{s}\right)\end{array}$ \\
\hline \multirow[t]{4}{*}{1981} & Apr. 14,1981 & 16.86 & 1,580 \\
\hline & June $\quad 8,1981$ & 18.47 & 2,800 \\
\hline & June 15,1981 & 19.36 & 3,890 \\
\hline & July $\quad 4,1981$ & 23.14 & 16,600 \\
\hline \multicolumn{4}{|c|}{ (October 1,1981 , base for partial-duration series changed from $1,200 \mathrm{ft}^{3} / \mathrm{s}$ to $1,600 \mathrm{ft}^{3} / \mathrm{s}$.) } \\
\hline \multirow[t]{8}{*}{1982} & Mar. 19,1982 & 18.54 & 2,880 \\
\hline & Apr. 17,1982 & 17.83 & 2,220 \\
\hline & May 7,1982 & 17.55 & 2,020 \\
\hline & May 21,1982 & 17.55 & 2,020 \\
\hline & May 29,1982 & 17.33 & 1,900 \\
\hline & July $\quad 3,1982$ & 18.97 & 3,360 \\
\hline & July 16,1982 & 19.85 & 4,650 \\
\hline & Aug. 30,1982 & 18.02 & 2,370 \\
\hline \multirow[t]{4}{*}{1983} & Oct. $\quad 9,1982$ & 20.74 & 6,530 \\
\hline & Dec. 6,1982 & 17.55 & 2,010 \\
\hline & Dec. 28,1982 & 16.82 & 1,630 \\
\hline & Apr. $\quad 2,1983$ & 17.73 & 2,420 \\
\hline \multirow[t]{6}{*}{1984} & Apr. 12,1984 & 16.34 & 1,630 \\
\hline & Apr. 22,1984 & 16.58 & 1,740 \\
\hline & Apr. 30,1984 & 17.07 & 1,970 \\
\hline & June 8,1984 & 17.17 & 1,780 \\
\hline & June 10,1984 & 17.16 & 1,730 \\
\hline & June 15,1984 & 16.73 & 1,620 \\
\hline \multirow[t]{2}{*}{1985} & Mar. 4,1985 & 16.67 & 1,730 \\
\hline & July 31,1985 & 19.01 & 5,120 \\
\hline \multirow[t]{6}{*}{1986} & Oct. 10,1985 & 17.40 & 2,030 \\
\hline & May 11,1986 & 16.71 & 1,720 \\
\hline & May 17,1986 & 19.04 & 3,460 \\
\hline & Aug. 16, 1986 & 16.38 & 1,610 \\
\hline & Sept. 19,1986 & 18.23 & 2,590 \\
\hline & Sept. 29,1986 & 16.70 & 1,720 \\
\hline \multirow[t]{6}{*}{1987} & Oct. 12,1986 & 16.95 & 2,250 \\
\hline & Apr. 15,1987 & 16.55 & 2,020 \\
\hline & May $\quad 4,1987$ & 16.14 & 1,700 \\
\hline & July 12,1987 & 16.30 & 1,780 \\
\hline & Aug. 26, 1987 & 19.62 & 6,720 \\
\hline & Sept. 17,1987 & 16.60 & 1,970 \\
\hline 1988 & Nov. 29,1987 & 16.40 & 1,840 \\
\hline 1989 & Sept. 9,1989 & 15.01 & 1,200 \\
\hline \multirow[t]{5}{*}{1990} & Apr. 28,1990 & 16.35 & 1,890 \\
\hline & May 5,1990 & 16.35 & 1,890 \\
\hline & May 25,1990 & 18.31 & 3,730 \\
\hline & June 17,1990 & 16.75 & 2,120 \\
\hline & July 22,1990 & 17.84 & 3,080 \\
\hline
\end{tabular}




\section{Chariton River near Chariton, Iowa}

Peak stage and discharges--Continued

\begin{tabular}{|c|c|c|c|}
\hline Water year & Date & $\begin{array}{l}\text { Gage height } \\
\text { (ft) }\end{array}$ & $\begin{array}{c}\text { Discharge } \\
\left(\mathrm{ft}^{3} / \mathrm{s}\right)\end{array}$ \\
\hline \multirow[t]{5}{*}{1991} & Apr. 14,1991 & 17.21 & 2,360 \\
\hline & Apr. 19,1991 & 19.07 & 6,010 \\
\hline & Apr. 27,1991 & 17.33 & 3,320 \\
\hline & Apr. 29,1991 & 18.04 & 4,180 \\
\hline & May 5,1991 & 17.29 & 3,280 \\
\hline \multirow[t]{5}{*}{1992} & Apr. 19,1992 & 17.64 & 2,960 \\
\hline & July 26,1992 & 16.99 & 2,280 \\
\hline & July 31,1992 & 17.00 & 2,290 \\
\hline & Aug. 1,1992 & 16.26 & 1,760 \\
\hline & Sept. 15,1992 & $\mathrm{l}_{29.32}$ & $\mathrm{f}_{37,700}$ \\
\hline \multirow[t]{11}{*}{1993} & Nov. 20,1992 & 16.73 & 2,070 \\
\hline & Dec. 15,1992 & 16.92 & 2,220 \\
\hline & Mar. 3, 1993 & 17.49 & 2,790 \\
\hline & Mar. 31, 1993 & 17.16 & 2,440 \\
\hline & May 7,1993 & 17.09 & 2,380 \\
\hline & July $\quad 5,1993$ & 22.60 & 14,900 \\
\hline & July 11,1993 & 18.08 & 3,500 \\
\hline & July 15,1993 & 16.53 & 1,920 \\
\hline & July 24,1993 & 17.72 & 3,050 \\
\hline & Aug. 19,1993 & 16.67 & 2,030 \\
\hline & Sept. 26,1993 & 16.19 & 1,710 \\
\hline 1994 & Mar. 5, 1994 & 16.10 & 1,660 \\
\hline \multirow[t]{7}{*}{1995} & Apr. 11,1995 & 16.07 & 1,880 \\
\hline & May 8,1995 & 18.22 & 4,120 \\
\hline & May 13,1995 & 17.62 & 3,410 \\
\hline & May 24,1995 & 17.37 & 3,100 \\
\hline & May 28,1995 & 17.57 & 3,350 \\
\hline & June 29,1995 & 16.14 & 1,920 \\
\hline & July $\quad 5,1995$ & 16.10 & 1,890 \\
\hline
\end{tabular}

${ }^{\text {bApproximate. }}$

${ }^{\mathrm{e}}$ Affected by ice.

${ }^{f}$ Discharge computed from indirect measurement.

${ }^{1}$ Gage height determined from floodmarks. 


\section{Honey Creek near Russell, Iowa}

(Discontinued September 30, 1962)

Location.--Lat $40^{\circ} 55^{\prime} 25^{\prime \prime}$, long 9307'55", in SW1/4 NW1/4 sec. 26, T.71 N., R.20 W., Lucas County, on left bank $15 \mathrm{ft}$ downstream from county road bridge, 0.7 mi upstream from mouth, and $5.5 \mathrm{mi}$ southeast of Russell.

Drainage area.--13.2 $\mathrm{mi}^{2}$.

Gage.--Water-stage recorder. Datum of gage is $901.73 \mathrm{ft}$ above sea level (levels by Soil Conservation Service).

Stage-discharge relation.--Defined by current meter measurements and above $640 \mathrm{ft}^{3} / \mathrm{s}$ by indirect measurements.

Remarks.--Base for partial-duration series, $250 \mathrm{ft}^{3} / \mathrm{s}$.

Peak stages and discharges

[Water year, October 1-September 30; $\mathrm{ft}$, feet above gage datum; $\mathrm{ft}^{3} / \mathrm{s}$, cubic feet per second]

\begin{tabular}{|c|c|c|c|}
\hline Water year & Date & $\begin{array}{c}\text { Gage height } \\
\text { (ft) }\end{array}$ & $\begin{array}{c}\text { Discharge } \\
\left(\mathrm{ft}^{3} / \mathrm{s}\right)\end{array}$ \\
\hline \multicolumn{4}{|c|}{ (Systematic operation of gage began in June 1952.) } \\
\hline 1952 & June 21,1952 & 9.86 & 586 \\
\hline \multirow[t]{3}{*}{1953} & Feb. 20,1953 & 7.12 & 250 \\
\hline & Mar. 30,1953 & 8.37 & 388 \\
\hline & June 10,1953 & 7.32 & 265 \\
\hline 1954 & Apr. 26,1954 & 7.10 & 245 \\
\hline 1955 & Feb. 19,1955 & 6.27 & 170 \\
\hline 1956 & July 31,1956 & 7.34 & 265 \\
\hline \multirow[t]{2}{*}{1957} & Apr. 22,1957 & 7.17 & 263 \\
\hline & May 21,1957 & 7.11 & 254 \\
\hline \multirow[t]{5}{*}{1958} & Feb. 24,1958 & 7.20 & 273 \\
\hline & July $\quad 2,1958$ & 8.86 & 638 \\
\hline & July $\quad 4,1958$ & 8.32 & 418 \\
\hline & July 30,1958 & 8.84 & 394 \\
\hline & Sept. 23,1958 & 7.12 & 264 \\
\hline \multirow[t]{8}{*}{1959} & Mar. 19,1959 & ${ }^{e} 8.19$ & $\mathrm{~b}_{470}$ \\
\hline & Mar. 26, 1959 & $\mathrm{e}_{7.97}$ & $\mathrm{~b}_{400}$ \\
\hline & Apr. $\quad 1,1959$ & 8.48 & 669 \\
\hline & Apr. 20,1959 & $\mathrm{~m}_{8.40}$ & $b_{450}$ \\
\hline & Apr. 27,1959 & 7.26 & 296 \\
\hline & May 21,1959 & 11.26 & $f_{4,100}$ \\
\hline & May 30,1959 & 8.89 & 645 \\
\hline & Sept. 27,1959 & 7.06 & 270 \\
\hline \multirow[t]{8}{*}{1960} & Dec. 28,1959 & $\mathrm{~m}_{7.49}$ & $\mathrm{~b}_{260}$ \\
\hline & Jan. 12,1960 & 8.51 & 669 \\
\hline & Mar. 28,1960 & 9.16 & 1,080 \\
\hline & Apr. 16,1960 & 8.92 & 900 \\
\hline & May 6,1960 & 9.33 & 1,260 \\
\hline & May 16,1960 & $\mathrm{~m}_{7.57}$ & $\mathrm{~b}_{1,000}$ \\
\hline & May 20,1960 & 7.51 & 340 \\
\hline & May 24,1960 & 7.28 & 303 \\
\hline
\end{tabular}




\section{Honey Creek near Russell, Iowa}

Peak stages and discharges--Continued

\begin{tabular}{cccr}
\hline Water year & \multicolumn{1}{c}{ Date } & $\begin{array}{c}\text { Gage height } \\
(\mathbf{f t})\end{array}$ & $\begin{array}{c}\text { Discharge } \\
\left(\mathbf{f t}^{3} / \mathbf{s}\right)\end{array}$ \\
\hline 1961 & Feb. 18, 1961 & $\mathrm{m}^{\mathrm{m}} \mathbf{8 . 3 0}$ & 450 \\
& Mar. 6, 1961 & 9.51 & 1,390 \\
& Mar. 13, 1961 & $\mathrm{m}_{8.58}$ & $\mathrm{~b}_{450}$ \\
& Mar. 27, 1961 & 7.97 & 448 \\
& Sept. 13, 1961 & $\mathrm{m}_{9} 9.88$ & $\mathrm{~b}_{1,000}$ \\
& Sept. 30, 1961 & $\mathrm{m}_{8.00}$ & $\mathrm{~b}_{400}$ \\
& Nov. 2, 1961 & $\mathrm{m}_{9.66}$ & $\mathrm{~b}_{1,000}$ \\
& Nov. 13, 1961 & 7.68 & 382 \\
& Nov. 16, 1961 & 9.55 & $\mathrm{~b}_{1,100}$ \\
& May 29, 1962 & $\mathrm{m}_{8.18}$ & $\mathrm{~b}_{300}$ \\
& June 11, 1962 & 7.27 & 296 \\
\hline
\end{tabular}

bApproximate.

${ }^{\mathrm{e}}$ Affected by ice.

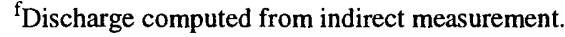

${ }^{m}$ Gage height affected by backwater. 


\section{South Fork Chariton River near Promise City, Iowa}

Location.--Lat 4048'02", long 93'11'32", in SW1/4 SW1/4 sec. 5, T.69 N., R.20 W., Wayne County, Hydrologic Unit 10280201, on right bank $20 \mathrm{ft}$ downstream from bridge on County Road S50, 1.3 mi downstream from Jordan Creek, and 4.3 mi northwest of Promise City.

Drainage area.--168 $\mathrm{mi}^{2}$.

Gage.--Water-stage recorder. Datum of gage is $913.70 \mathrm{ft}$ above sea level (U.S. Army Corps of Engineers bench mark).

Stage-discharge relation.--Defined by current-meter and indirect measurements.

Flood-stage.-- $18 \mathrm{ft}$.

Remarks.--Base for partial-duration series, $2,000 \mathrm{ft}^{3} / \mathrm{s}$.

\section{Peak stages and discharges}

[Water year, October 1-September 30; ft, feet above gage datum; $\mathrm{ft}^{3} / \mathrm{s}$, cubic feet per second; --, not determined]

\begin{tabular}{|c|c|c|c|}
\hline Water year & Date & $\begin{array}{c}\text { Gage height } \\
\text { (ft) }\end{array}$ & $\begin{array}{c}\text { Discharge } \\
\left(\mathrm{ft}^{3} / \mathrm{s}\right)\end{array}$ \\
\hline 1965 & Sept. 21,1965 & 25.5 & ${ }^{b} 18,000$ \\
\hline \multirow[t]{2}{*}{1968} & Apr. 20,1968 & 14.60 & 2,710 \\
\hline & Apr. 23,1968 & 20.96 & 6,950 \\
\hline \multirow[t]{3}{*}{1969} & Jan. 16,1969 & $\mathrm{e}_{15.05}$ & $\mathrm{~b}_{1,900}$ \\
\hline & Apr. 27,1969 & 14.29 & 2,600 \\
\hline & July 13,1969 & 13.81 & 2,290 \\
\hline \multirow[t]{6}{*}{1970} & Apr. 18,1970 & 13.69 & 2,250 \\
\hline & May 14,1970 & 19.12 & 4,280 \\
\hline & Aug. 8,1970 & 21.32 & 7,660 \\
\hline & Sept. 17,1970 & 20.44 & 6,160 \\
\hline & Sept. 22,1970 & 18.61 & 4,420 \\
\hline & Sept. 24,1970 & 14.53 & 2,690 \\
\hline \multirow[t]{4}{*}{1971} & Oct. $\quad 9,1970$ & 20.98 & 6,970 \\
\hline & Feb. 18,1971 & $\mathrm{e}_{18.93}$ & $b_{3,300}$ \\
\hline & Feb. 26,1971 & $\mathrm{e}_{14.90}$ & $b_{2,300}$ \\
\hline & Mar. 11,1971 & 12.38 & 2,010 \\
\hline 1972 & Sept. 14, 1972 & 17.68 & 3,930 \\
\hline \multirow[t]{14}{*}{1973} & Dec. 29,1972 & -- & $\mathrm{b}_{3,000}$ \\
\hline & Jan. 17,1973 & -- & $b_{2,600}$ \\
\hline & Feb. $\quad 2,1973$ & 18.73 & 4,500 \\
\hline & Mar. 7,1973 & 14.60 & 2,710 \\
\hline & Mar. 11,1973 & 13.97 & 2,490 \\
\hline & Mar. 25, 1973 & 18.41 & 4,300 \\
\hline & Mar. 31, 1973 & 19.14 & 4,810 \\
\hline & Apr. 12,1973 & 14.82 & 2,800 \\
\hline & Apr. 16,1973 & 19.21 & 4,870 \\
\hline & Apr. 21,1973 & 12.78 & 2,130 \\
\hline & May 2,1973 & 18.81 & 4,560 \\
\hline & May 7,1973 & 14.82 & 2,790 \\
\hline & May 27,1973 & 18.20 & 4,170 \\
\hline & June 18,1973 & 13.25 & 2,280 \\
\hline
\end{tabular}


06903700 South Fork Chariton River near Promise City, Iowa

Peak stages and discharges--Continued

\begin{tabular}{|c|c|c|c|}
\hline Water year & Date & $\begin{array}{c}\text { Gage height } \\
\text { (ft) }\end{array}$ & $\begin{array}{c}\text { Discharge } \\
\left(\mathrm{ft}^{3} / \mathrm{s}\right)\end{array}$ \\
\hline \multirow[t]{8}{*}{1974} & Oct. 3,1973 & 15.13 & 2,900 \\
\hline & Oct. 12,1973 & 19.35 & 4,980 \\
\hline & Dec. 4,1973 & 12.49 & 2,030 \\
\hline & Jan. 27,1974 & $\mathrm{e}_{17.72}$ & $\mathrm{~b}_{3,000}$ \\
\hline & May 31,1974 & 15.43 & 3,000 \\
\hline & June 9,1974 & 18.98 & 4,680 \\
\hline & June 13,1974 & 14.34 & 2,620 \\
\hline & July $\quad 4,1974$ & 16.80 & 3,540 \\
\hline \multirow[t]{2}{*}{1975} & Apr. 24,1975 & 13.06 & 2,170 \\
\hline & June 28,1975 & 20.85 & 6,580 \\
\hline \multirow[t]{4}{*}{1976} & Mar. $\quad 5,1976$ & 17.88 & 4,030 \\
\hline & Apr. 24,1976 & 20.27 & 5,930 \\
\hline & May 16,1976 & 14.25 & 2,590 \\
\hline & June 14,1976 & 20.29 & 5,960 \\
\hline \multirow[t]{2}{*}{1977} & Aug. 26, 1977 & 18.75 & 4,520 \\
\hline & Sept. 13, 1977 & 15.27 & 2,940 \\
\hline \multirow[t]{7}{*}{1978} & Oct. 24,1977 & 19.72 & 5,300 \\
\hline & Oct. 31,1977 & 17.08 & 3,660 \\
\hline & Apr. 10,1978 & 21.92 & 9,700 \\
\hline & Apr. 18,1978 & 18.74 & 4,510 \\
\hline & May 7,1978 & 19.78 & 5,460 \\
\hline & May 13,1978 & 18.32 & 4,250 \\
\hline & Sept. 20,1978 & 17.73 & 3,970 \\
\hline \multirow[t]{6}{*}{1979} & Mar. $\quad 4,1979$ & $\mathrm{e}_{19.74}$ & $b_{2,900}$ \\
\hline & Mar. 13, 1979 & 14.73 & 2,710 \\
\hline & Mar. 24, 1979 & 19.18 & 4,910 \\
\hline & May 3,1979 & 16.59 & 3,480 \\
\hline & June $\quad 8,1979$ & 12.59 & 2,100 \\
\hline & June 27,1979 & 15.40 & 3,000 \\
\hline \multirow[t]{4}{*}{1980} & June 3,1980 & 22.92 & 11,200 \\
\hline & June 4,1980 & 19.61 & 5,800 \\
\hline & Sept. $\quad 1,1980$ & 21.48 & 8,550 \\
\hline & Sept. 5,1980 & 12.83 & 2,140 \\
\hline \multirow[t]{6}{*}{1981} & Dec. 8,1980 & 18.20 & 4,190 \\
\hline & Apr. 12,1981 & 12.67 & 2,120 \\
\hline & Apr. 14,1981 & 17.58 & 3,940 \\
\hline & June 8,1981 & 16.18 & 3,290 \\
\hline & July $\quad 4,1981$ & 29.95 & 28,000 \\
\hline & July 15,1981 & 17.38 & 3,790 \\
\hline
\end{tabular}


06903700 South Fork Chariton River near Promise City, Iowa

Peak stages and discharges--Continued

\begin{tabular}{|c|c|c|c|}
\hline Water year & Date & $\begin{array}{c}\text { Gage height } \\
\text { (ft) }\end{array}$ & $\begin{array}{c}\text { Discharge } \\
\left(\mathrm{ft}^{3} / \mathrm{s}\right)\end{array}$ \\
\hline \multirow[t]{12}{*}{1982} & Feb. 20,1982 & $e_{--}$ & $b_{2,140}$ \\
\hline & Mar. 16,1982 & 14.43 & 2,510 \\
\hline & Mar. 19,1982 & 21.97 & 9,420 \\
\hline & Apr. 16,1982 & 16.37 & 3,320 \\
\hline & May 6,1982 & 14.25 & 2,450 \\
\hline & May 21,1982 & 12.93 & 2,010 \\
\hline & May 29,1982 & 20.27 & 6,680 \\
\hline & June 9,1982 & 12.99 & 2,030 \\
\hline & July 16,1982 & 22.32 & 10,000 \\
\hline & July 19,1982 & 20.24 & 6,640 \\
\hline & July 21,1982 & 17.84 & 4,050 \\
\hline & Sept. 17,1982 & 15.24 & 2,850 \\
\hline \multirow[t]{6}{*}{1983} & Oct. $\quad 9,1982$ & $\mathrm{~m}_{20.57}$ & 4,380 \\
\hline & Nov. 12,1982 & 17.99 & 4,140 \\
\hline & Dec. 5,1982 & 19.39 & 5,520 \\
\hline & Dec. 28,1982 & 17.74 & 3,970 \\
\hline & Apr. $\quad 2,1983$ & 19.43 & 5,570 \\
\hline & Apr. 12,1983 & 17.99 & 4,140 \\
\hline \multirow[t]{4}{*}{1984} & Apr. 22,1984 & 15.58 & 2,710 \\
\hline & Apr. 30,1984 & 19.21 & 5,600 \\
\hline & May 20,1984 & 16.88 & 3,290 \\
\hline & June 10,1984 & 19.83 & 6,500 \\
\hline \multirow[t]{3}{*}{1985} & Feb. 21,1985 & $e_{18.06}$ & -- \\
\hline & Mar. 4,1985 & 16.36 & 3,040 \\
\hline & Sept. 30,1985 & 14.86 & 2,490 \\
\hline \multirow[t]{9}{*}{1986} & Oct. 10,1985 & 20.36 & 6,850 \\
\hline & Oct. 19,1985 & 17.48 & 3,640 \\
\hline & Apr. 30,1986 & 13.24 & 2,010 \\
\hline & May 10,1986 & 17.03 & 3,370 \\
\hline & May 17,1986 & 20.95 & 7,710 \\
\hline & July 14,1986 & 15.25 & 2,630 \\
\hline & Aug. 13, 1986 & 14.21 & 2,320 \\
\hline & Sept. 23, 1986 & 14.21 & 2,320 \\
\hline & Sept. 29,1986 & 18.32 & 4,420 \\
\hline \multirow[t]{7}{*}{1987} & Oct. 3,1986 & 15.12 & 2,570 \\
\hline & Oct. 12,1986 & 17.85 & 3,880 \\
\hline & May 3,1987 & 13.61 & 2,130 \\
\hline & July 12,1987 & 14.89 & 2,500 \\
\hline & Aug. 15, 1987 & 15.17 & 2,570 \\
\hline & Aug. 26, 1987 & 18.45 & 4,490 \\
\hline & Sept. 17,1987 & 15.24 & 2,550 \\
\hline 1988 & Nov. 28,1987 & 15.71 & 2,770 \\
\hline 1989 & Sept. 9,1989 & 12.40 & 1,770 \\
\hline
\end{tabular}


06903700 South Fork Chariton River near Promise City, Iowa

Peak stages and discharges--Continued

\begin{tabular}{|c|c|c|c|}
\hline Water year & Date & $\begin{array}{c}\text { Gage height } \\
\text { (ft) }\end{array}$ & $\begin{array}{c}\text { Discharge } \\
\left(\mathrm{ft}^{3} / \mathrm{s}\right)\end{array}$ \\
\hline \multirow[t]{9}{*}{1990} & Apr. 28,1990 & 16.06 & 2,800 \\
\hline & May 4,1990 & 16.34 & 2,940 \\
\hline & May 25,1990 & 19.51 & 5,720 \\
\hline & June 17,1990 & 20.39 & 6,890 \\
\hline & June 20,1990 & 15.84 & 2,700 \\
\hline & June 22,1990 & 15.51 & 2,590 \\
\hline & July 20,1990 & 19.06 & 5,130 \\
\hline & July 21,1990 & 14.00 & 2,110 \\
\hline & July 29,1990 & 16.42 & 2,970 \\
\hline \multirow[t]{6}{*}{1991} & Apr. 13,1991 & 13.76 & 2,050 \\
\hline & Apr. 14,1991 & 18.19 & 3,820 \\
\hline & Apr. 19,1991 & 20.49 & 6,470 \\
\hline & Apr. 27,1991 & 17.12 & 3,210 \\
\hline & Apr. 29,1991 & 20.70 & 6,760 \\
\hline & May 5,1991 & 19.93 & 5,740 \\
\hline \multirow[t]{8}{*}{1992} & Apr. 11,1992 & 17.20 & 3,550 \\
\hline & Apr. 19,1992 & 20.27 & 6,850 \\
\hline & Apr. 20,1992 & 17.02 & 3,500 \\
\hline & July 16,1992 & 13.44 & 2,140 \\
\hline & July 19,1992 & 14.70 & 2,480 \\
\hline & July 30,1992 & 18.30 & 4,320 \\
\hline & Sept. 15,1992 & 34.84 & $\mathrm{f}_{70,600}$ \\
\hline & Sept. 18,1992 & 17.34 & 4,150 \\
\hline \multirow[t]{16}{*}{1993} & Nov. 20,1992 & 17.01 & 3,780 \\
\hline & Mar. 2, 1993 & 17.15 & 3,440 \\
\hline & Mar. 31, 1993 & 18.30 & 4,310 \\
\hline & Apr. $\quad 8,1993$ & 14.12 & 2,280 \\
\hline & May 7,1993 & 19.05 & 5,160 \\
\hline & June 8,1993 & 18.21 & 4,200 \\
\hline & July $\quad 5,1993$ & 25.09 & 16,900 \\
\hline & July $\quad 8,1993$ & 15.94 & 2,870 \\
\hline & July $\quad 9,1993$ & 17.63 & 3,720 \\
\hline & July 11,1993 & 20.76 & 7,430 \\
\hline & July 13,1993 & 13.46 & 2,090 \\
\hline & July 14,1993 & 17.64 & 3,730 \\
\hline & July 20,1993 & 18.20 & 4,180 \\
\hline & July 22,1993 & 18.20 & 4,180 \\
\hline & July 24,1993 & 22.07 & 9,600 \\
\hline & Sept. 25,1993 & 13.57 & 2,120 \\
\hline \multirow[t]{2}{*}{1994} & Feb. 20,1994 & $\mathrm{e}_{14.00}$ & -- \\
\hline & June 12,1994 & 12.10 & 1,710 \\
\hline
\end{tabular}




\section{South Fork Chariton River near Promise City, Iowa}

Peak stages and discharges--Continued

\begin{tabular}{cccc}
\hline Water year & Date & $\begin{array}{c}\text { Gage height } \\
(\mathbf{f t})\end{array}$ & $\begin{array}{c}\text { Discharge } \\
\left(\mathbf{f t}^{3} / \mathbf{s}\right)\end{array}$ \\
\hline 1995 & Apr. 11, 1995 & 17.52 & 4,370 \\
& May 8, 1995 & 19.63 & 6,650 \\
& May 13,1995 & 18.07 & 4,900 \\
May 23, 1995 & 20.39 & 7,640 \\
& May 28, 1995 & 19.87 & 6,960 \\
& June 6, 6,1995 & 13.84 & 2,440 \\
& June 8, 1995 & 12.77 & 2,070 \\
& July 5, 5995 & 19.20 & 6,130 \\
& July 8, 8995 & 13.84 & 2,440 \\
\hline
\end{tabular}

${ }^{\mathrm{b}}$ Approximate.

eAffected by ice.

${ }^{\mathrm{f}}$ Discharge computed from indirect measurement.

${ }^{\mathrm{I}}$ Gage height determined from floodmarks.

${ }^{\mathrm{m}}$ Gage height affected by backwater. 


\section{APPENDIX B}

\section{WATER-SURFACE-ELEVATION PROFILES FOR THE THOMPSON, WELDON, AND CHARITON RIVER BASINS, SOUTH-CENTRAL IOWA}




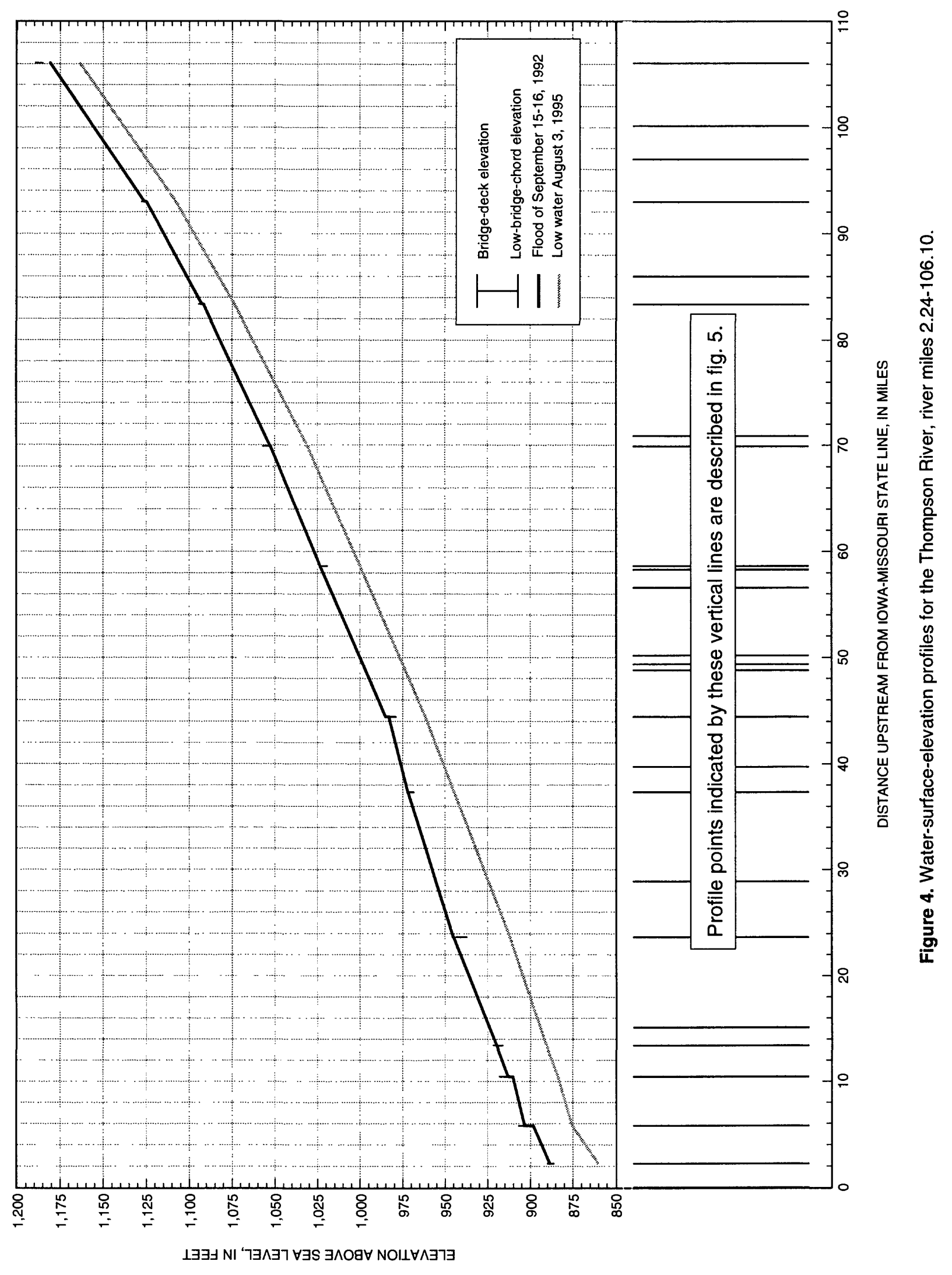




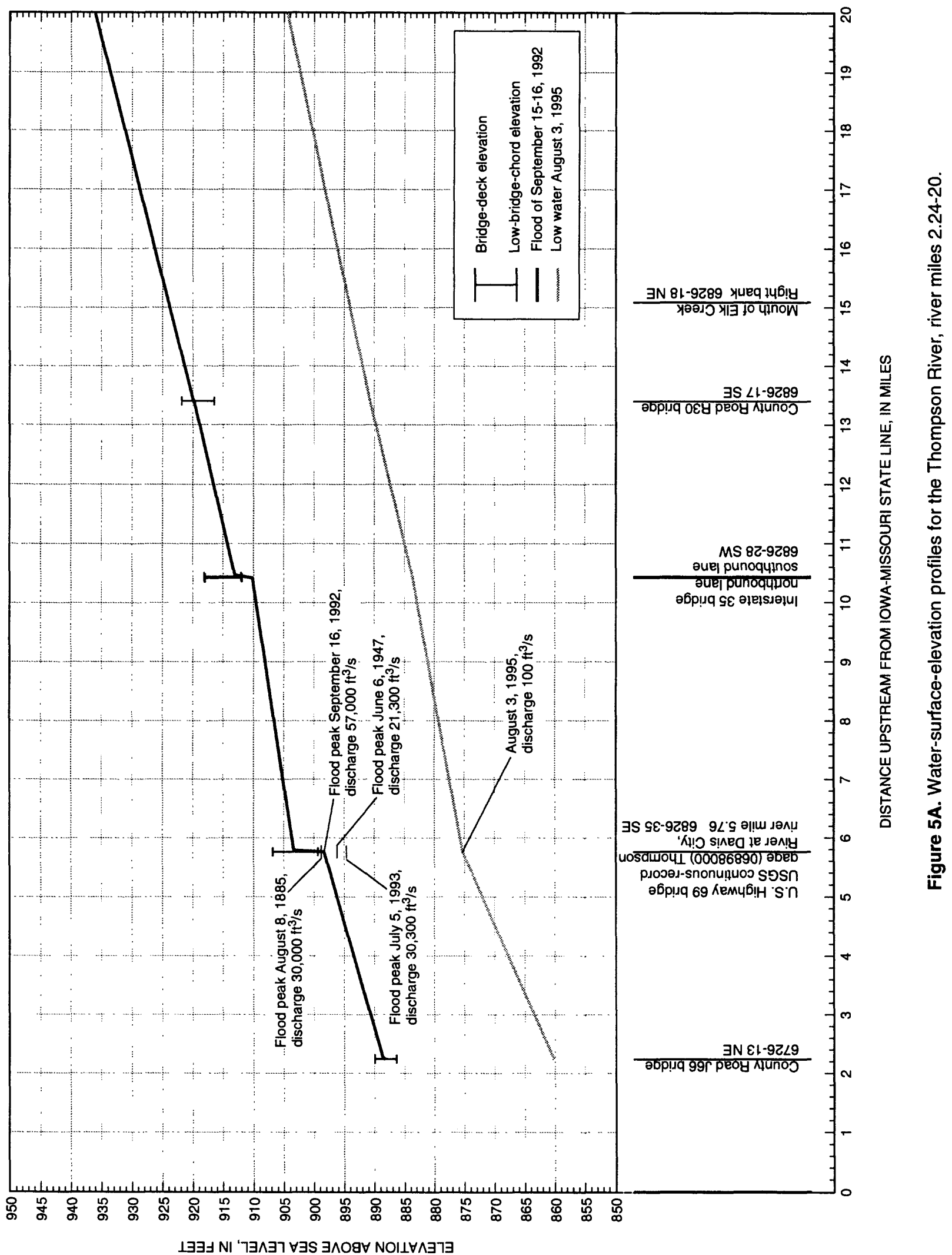




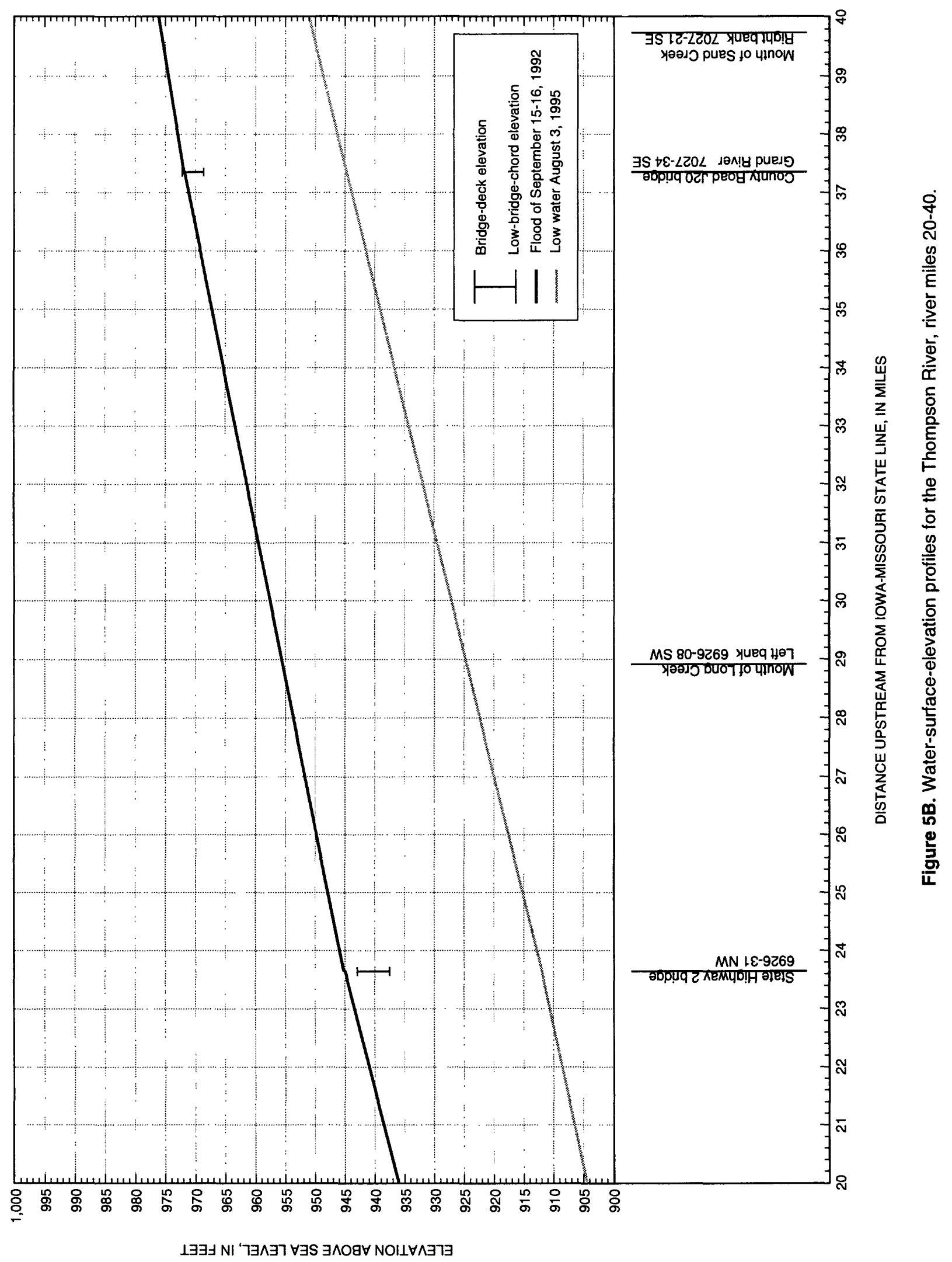




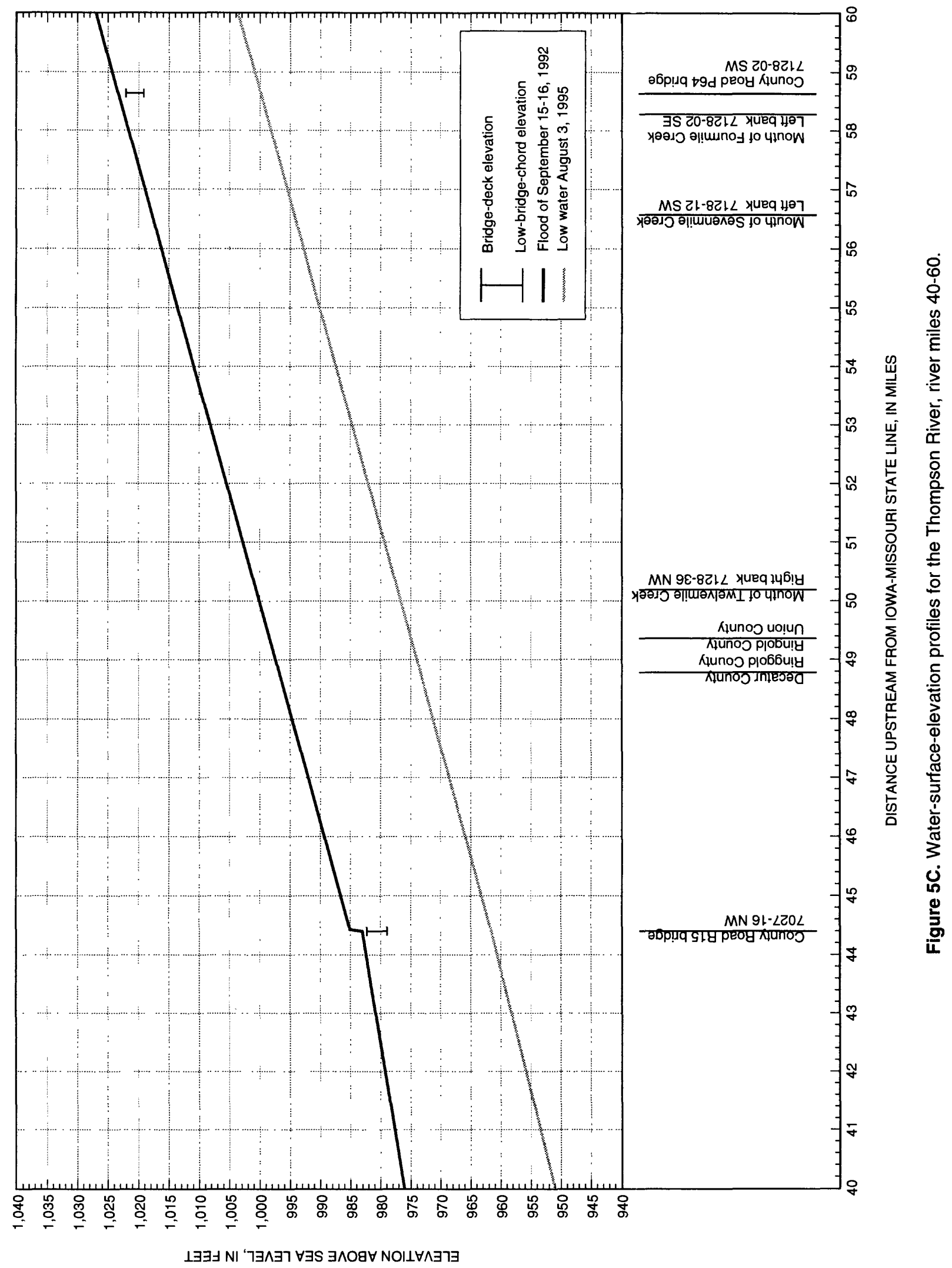




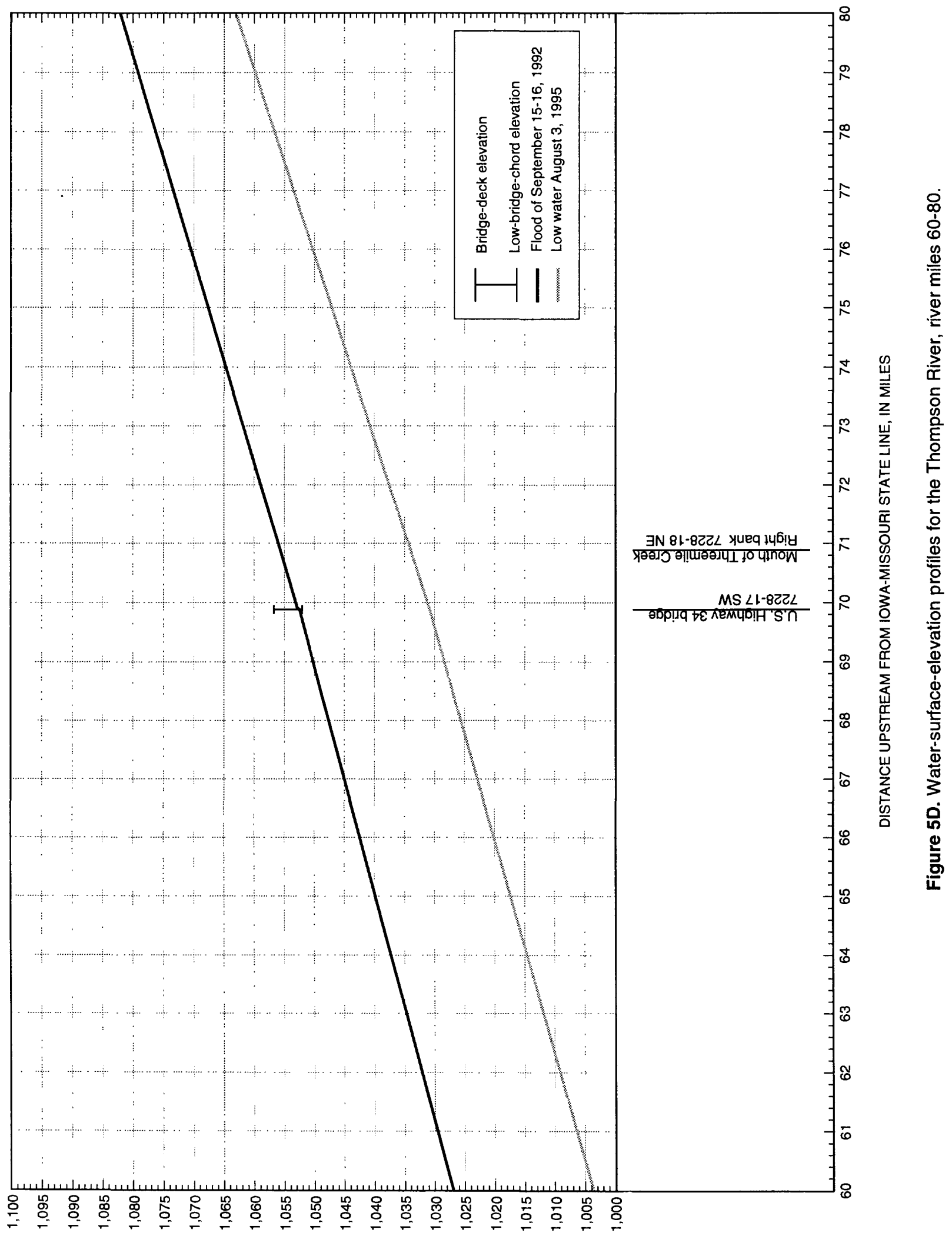

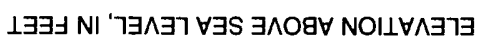




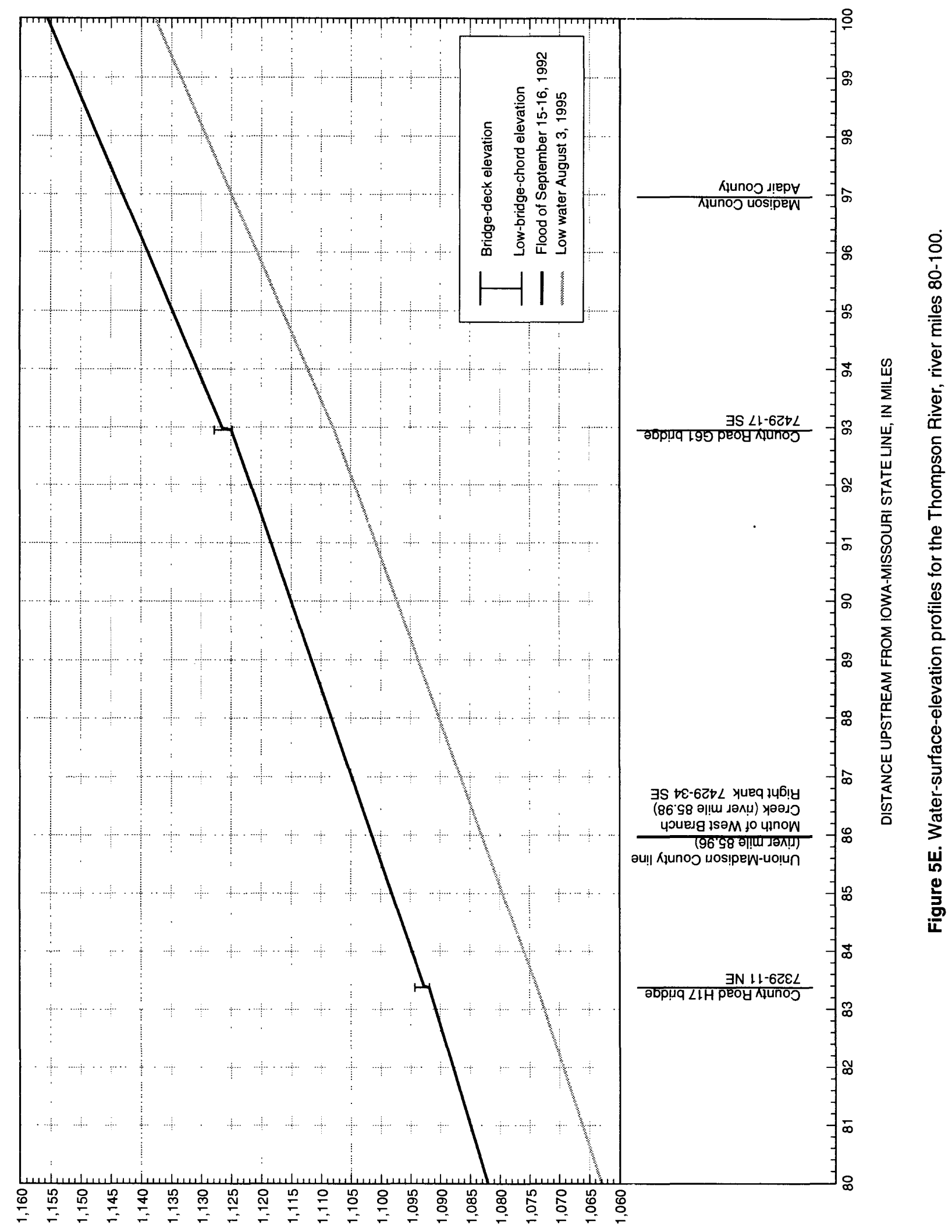

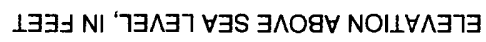




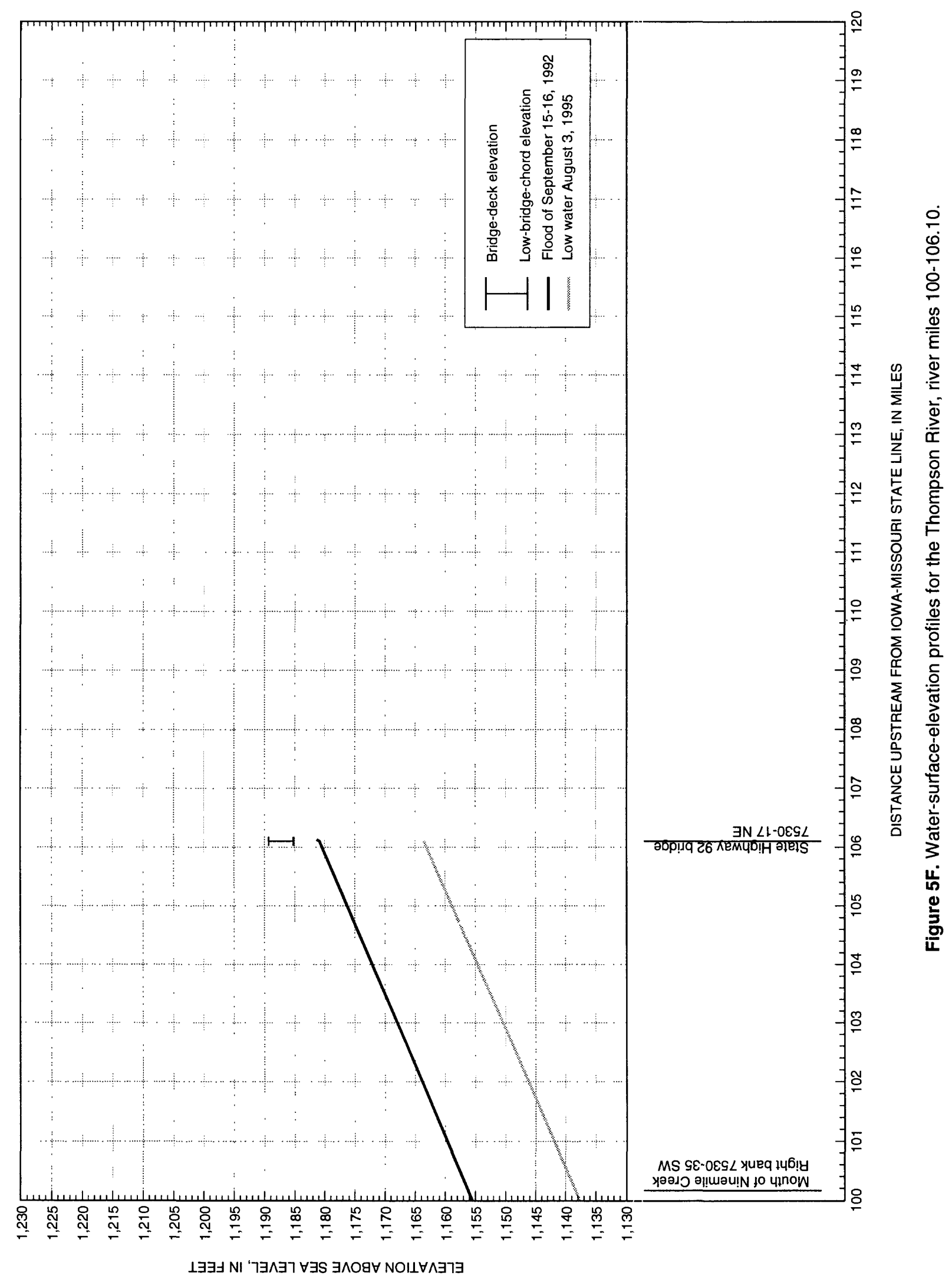




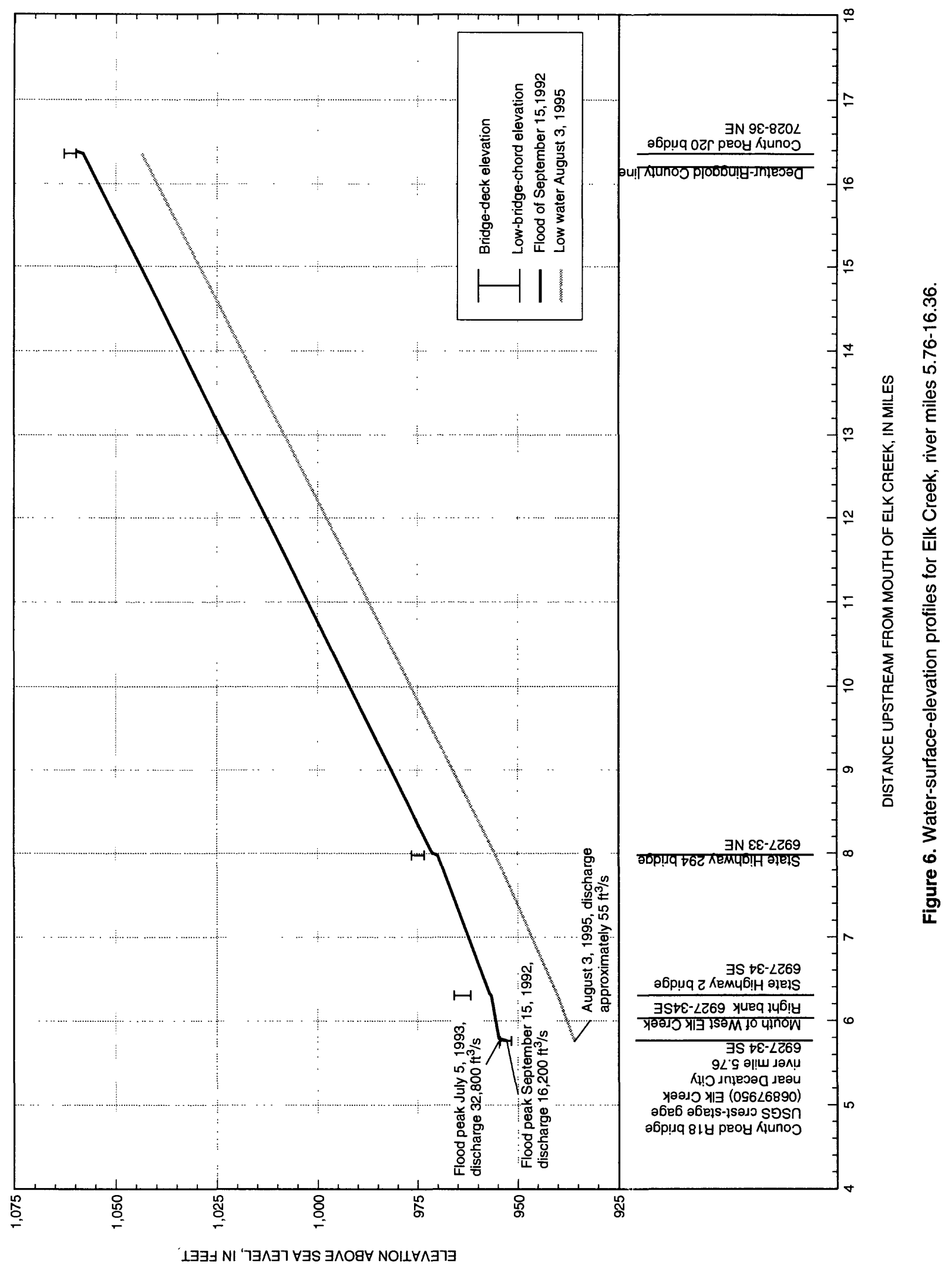




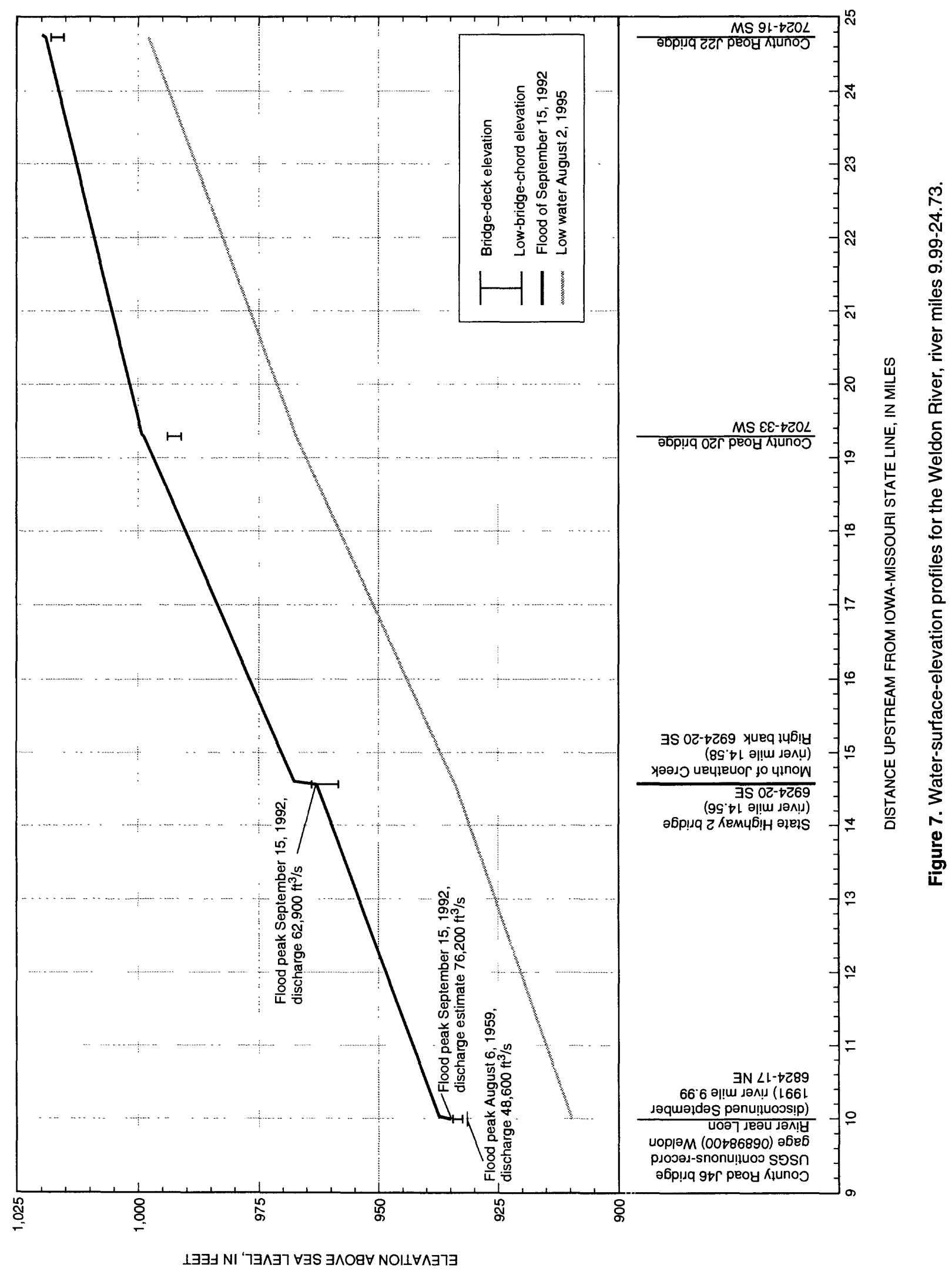




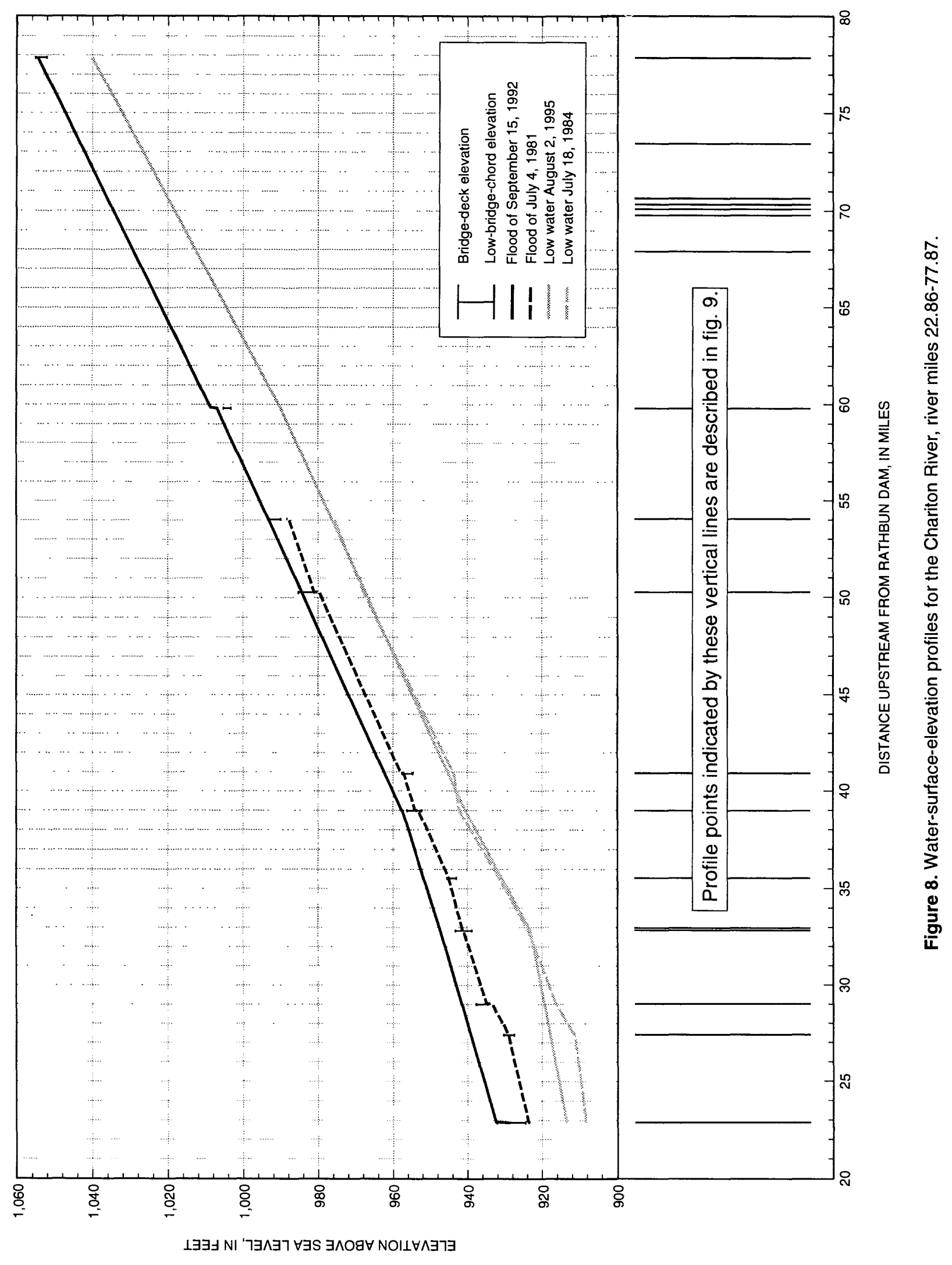



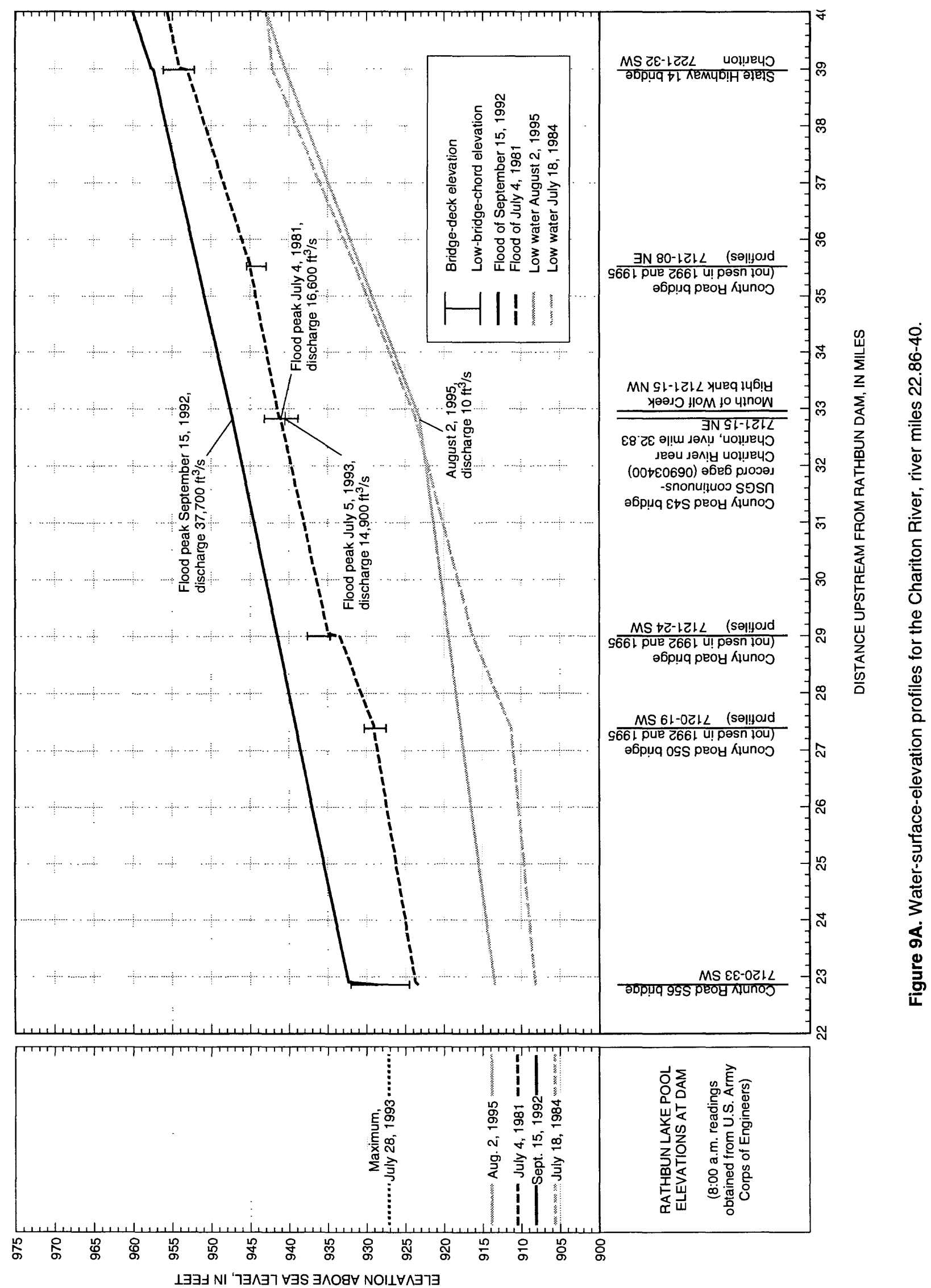


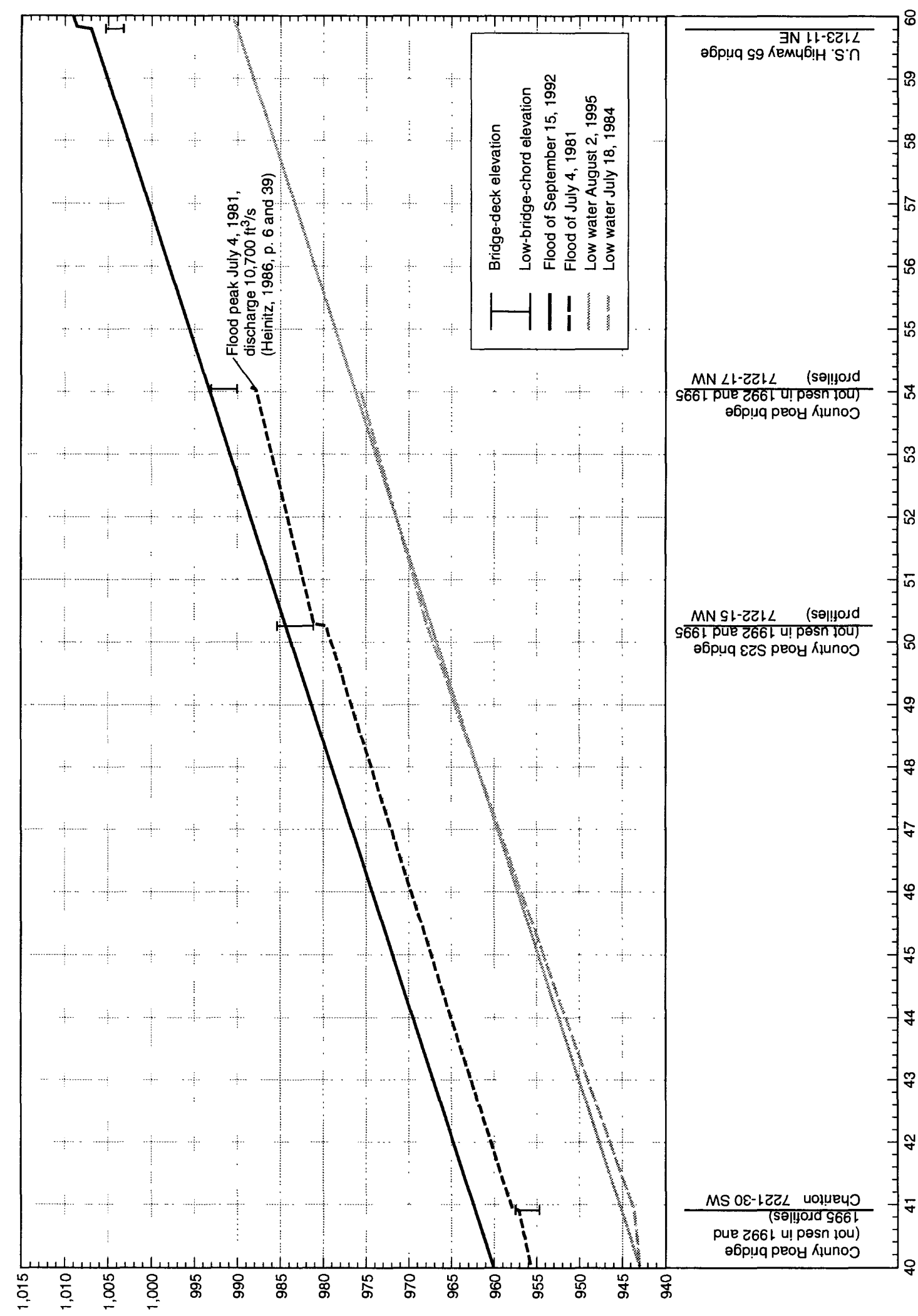

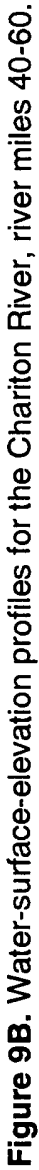

$1 \exists \exists \exists \mathrm{NI} ' \mathrm{\top} \exists \wedge \exists 7 \forall \exists S \exists \Lambda 08 \forall$ NOII $\forall \wedge \exists 7 \exists$ 


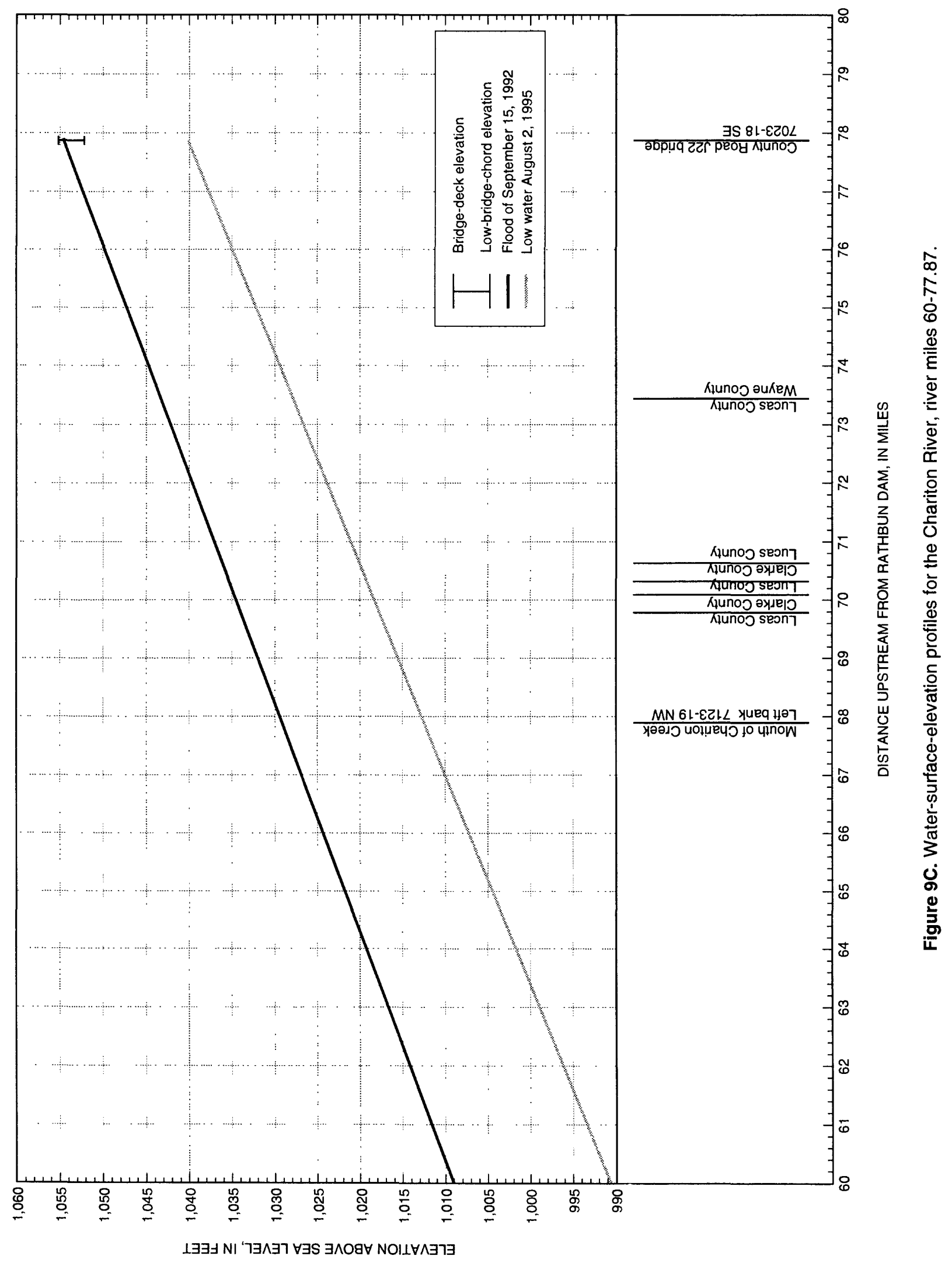



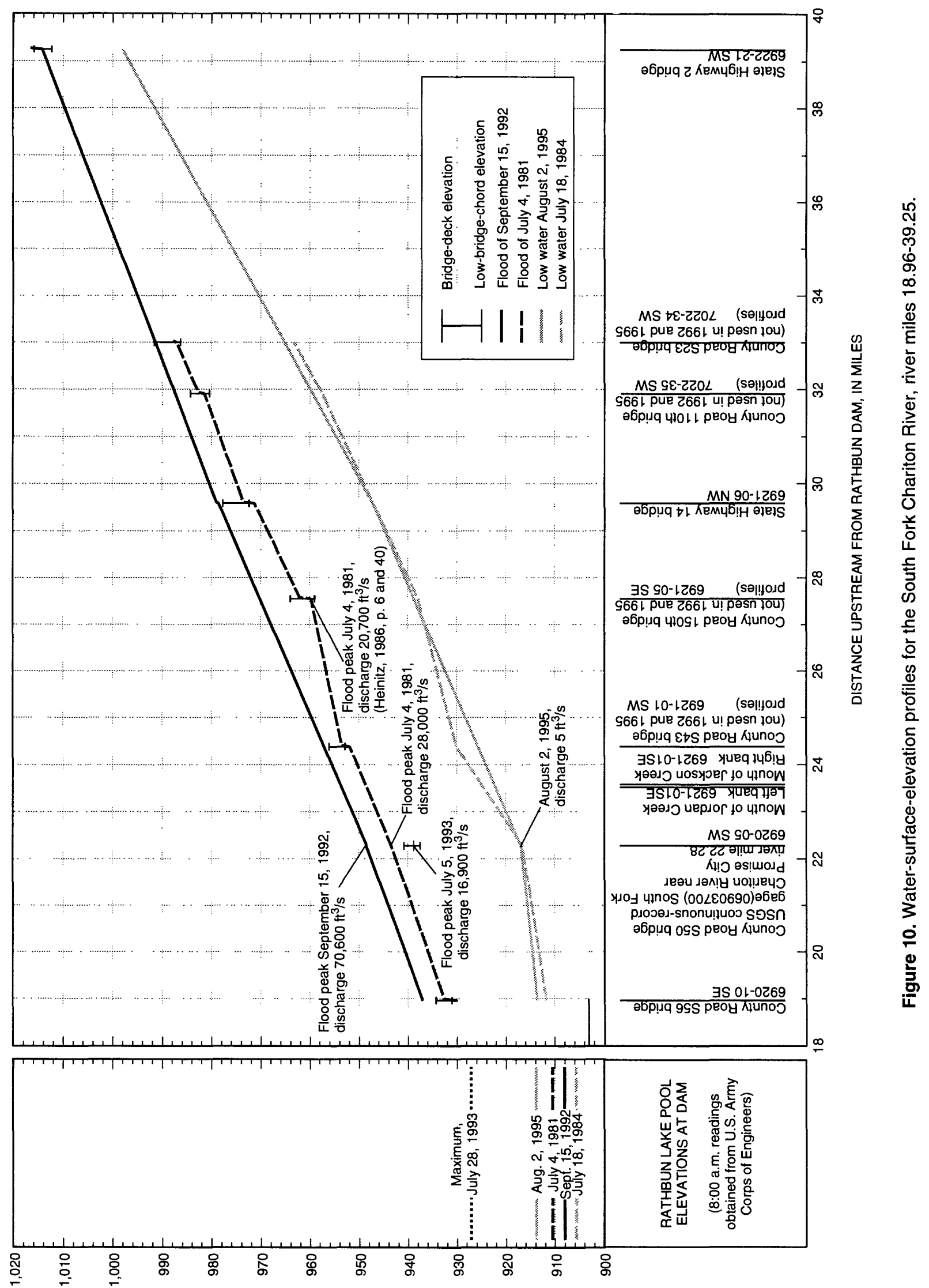

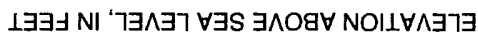




\section{APPENDIX C}

\section{TEMPORARY BENCH MARKS AND REFERENCE POINTS IN THE THOMPSON, WELDON, AND CHARITON RIVER BASINS, SOUTH-CENTRAL IOWA}

To facilitate measuring and referencing the highwater marks used in the flood profiles to a common datum, temporary bench marks (BM) and reference points (RP) were established by the USGS at many of the bridges along the profiled river reaches. All BM and RP elevations listed in this tabulation are referenced to sea level. BMs and RPs are listed only for those bridge sites used in the September 1516, 1992, flood profiles. The BMs and RPs were established in the Thompson and Weldon River Basins during 1994-95, and in the Chariton River Basin during 1983-84 and 199495. BM and RP elevations were determined from differential leveling. Level lines to establish the third-order accuracy of the BMs and RPs shown herein were surveyed from bench marks established and adjusted by the National Mapping Division of the USGS and the National Geodetic Survey. Errors of closure in the USGS level work were adjusted along the level lines to balance the BM and RP elevations. BMs and RPs established by other agencies are noted in the bench-mark descriptions where they occur.

The BMs and RPs are designated by an index number derived from their respective locations using Public Land Survey System coordinates (township, range, section). Within the section, the quarter in which the BM or RP is located is designated by NE, SE, SW, or NW. For example, 6726-13 NE refers to a location in Township 67 North, Range 26 West, northeast quarter of section 13. A number in parentheses following the quarter-section designation indicates the number of the BM or RP in that particular quarter section. The index number serves to describe the landline location of the BM or RP without further reference in the body of the description.

Standard BMs and RPs such as chiseled squares, arrows, or crosses on concrete; filed arrows or marks on steel; or existing bolts on bridges were used. Existing BMs or RPs were used wherever available, and the agency responsible for the mark, when known, is indicated in the description. RPs are distinguished from BMs in this tabulation by the notation "(REFERENCE POINT)" following the index number. RPs were established to permit water-surface elevations to be determined by use of a tape and weight. The terms "right" and "left" in the descriptions are determined as viewed while facing in the downstream direction.

The user is cautioned that the BMs and RPs listed herein might have been disturbed, destroyed, or moved since the surveys were made. It is the responsibility of the user to determine the condition and the suitability of the BM or RP. 


\section{TEMPORARY BENCH MARKS AND REFERENCE POINTS IN THE THOMPSON, WELDON, AND CHARITON RIVER BASINS, SOUTH-CENTRAL IOWA}

6726-13 NE (1)--Approximately 2.2 mi southeast of Davis City, on County Road J66 bridge over Thompson River, on right downstream wingwall; top of 3/4-in. bolt.

Elevation $892.08 \mathrm{ft}$.

6726-13 NE (2)--Approximately $2.2 \mathrm{mi}$ southeast of Davis City, on County Road J66 bridge over Thompson River, on right upstream wingwall; top of 3/4-in. bolt.

\section{Elevation $891.98 \mathrm{ft}$.}

6726-13 NE (3)--(REFERENCE POINT) Approximately 2.2 mi southeast of Davis City, on County Road J66 bridge over Thompson River, on 22nd guardrail post from right downstream end of bridge; two filed marks.

Elevation $892.77 \mathrm{ft}$.

6826-17 SE (1)--Approximately 4.1 mi northwest of Davis City, on County Road R30 bridge over Thompson River, on left downstream wingwall; Iowa Highway Commission bench mark.

Elevation $924.38 \mathrm{ft}$.

6826-17 SE (2)--Approximately $4.1 \mathrm{mi}$ northwest of Davis City, on County Road R30 bridge over Thompson River, on right downstream wingwall; chiseled square.

Elevation $925.12 \mathrm{ft}$.

6826-17 SE (3)--(REFERENCE POINT) Approximately 4.1 mi northwest of Davis City, on County Road R30 bridge over Thompson River, on 23rd guardrail post from left downstream end of bridge; chiseled arrow.

Elevation $924.52 \mathrm{ft}$.

6826-28 SW (1)--Approximately 2.5 mi northwest of Davis City, on southbound lane of Interstate 35 bridge over Thompson River (upstream bridge), on right downstream wingwall; Iowa Highway Commission bench mark.

Elevation $929.46 \mathrm{ft}$.

6826-28 SW (2)--Approximately $2.5 \mathrm{mi}$ northwest of Davis City, on northbound lane of Interstate 35 bridge over Thompson River (downstream bridge), on left upstream wingwall; Iowa Highway Commission bench mark.

Elevation $920.31 \mathrm{ft}$.
6826-28 SW (3)--Approximately 2.5 mi northwest of Davis City, on southbound lane of Interstate 35 bridge over Thompson River (upstream bridge), on left upstream wingwall; chiseled square.

Elevation $920.34 \mathrm{ft}$.

6826-28 SW (4)--(REFERENCE POINT) Approximately $2.5 \mathrm{mi}$ northwest of Davis City, on southbound lane of Interstate 35 bridge over Thompson River (upstream bridge), on downstream guardrail and $154 \mathrm{ft}$ from left end of bridge; chiseled arrow.

Elevation $921.69 \mathrm{ft}$.

6826-35 SE (1)--At Davis City, on U.S. Highway 69 bridge over Thompson River, on upstream landward corner of capstone of right upstream concrete pier; U.S. Geological Survey bronze bench mark.

Elevation $901.70 \mathrm{ft}$.

6826-35 SE (2)--At Davis City, on U.S. Highway 69 bridge over Thompson River, on right downstream concrete pier at end of approach walkway to gage house; U.S. Geological Survey bronze bench mark.

Elevation $901.22 \mathrm{ft}$.

6920-05 SW (1)--Approximately 4.3 mi northwest of Promise City, near County Road S50 bridge over South Fork Chariton River, set in ground $10 \mathrm{ft}$ north of right downstream abutment, with sign marking location, U.S. Army Corps of Engineers brass bench mark.

Elevation $934.86 \mathrm{ft}$.

6920-05 SW (2)--Approximately 4.3 mi northwest of Promise City, on County Road S50 bridge over South Fork Chariton River, on streamward side of right downstream wingwall; chiseled square (U.S. Army Corps of Engineers).

Elevation $943.70 \mathrm{ft}$.

6920-10 SE (1)--Approximately $2.5 \mathrm{mi}$ north of Promise City, on County Road S56 bridge over South Fork Chariton River, on top of first guardrail post from left downstream end of bridge; two filed marks.

Elevation $936.73 \mathrm{ft}$.

6920-10 SE (2)--Approximately $2.5 \mathrm{mi}$ north of Promise City, on County Road S56 bridge over South Fork Chariton River, on right downstream wingwall; chiseled square.

Elevation $936.78 \mathrm{ft}$.

6920-10 SE (3)--(REFERENCE POINT) Approximately 2.5 mi north of Promise City, on County Road S56 bridge over South Fork Chariton River, on 20th guardrail post from right downstream end of bridge; filed arrow.

Elevation $936.97 \mathrm{ft}$. 
6921-06 NW (1)--Approximately $3.3 \mathrm{mi}$ north of Corydon, on State Highway 14 bridge over South Fork Chariton River, on left upstream wingwall; top of bolt.

Elevation 979.79 ft.

6921-06 NW (2)--(REFERENCE POINT) Approximately 3.3 mi north of Corydon, on State Highway 14 bridge over South Fork Chariton River, on downstream curb and $81 \mathrm{ft}$ from left end of bridge; chiseled arrow.

Elevation $978.34 \mathrm{ft}$.

6922-21 SW (1)--Approximately $3.6 \mathrm{mi}$ west of Corydon, on State Highway 2 bridge over South Fork Chariton River, on curb near left upstream wingwall; Iowa Highway Commission bench mark.

Elevation $1017.16 \mathrm{ft}$.

6922-21 SW (2)--Approximately $3.6 \mathrm{mi}$ west of Corydon, on State Highway 2 bridge over South Fork Chariton River, on corner of right downstream wingwall; chiseled square.

Elevation $1019.06 \mathrm{ft}$.

6922-21 SW (3)--(REFERENCE POINT) Approximately $3.6 \mathrm{mi}$ west of Corydon, on State Highway 2 bridge over South Fork Chariton River, $1 \mathrm{ft}$ left of 10th guardrail post or $74 \mathrm{ft}$ from left downstream end of bridge; chiseled arrow.

Elevation $1016.98 \mathrm{ft}$.

6924-20 SE (1)--Approximately 5.5 mi east of Leon, on State Highway 2 bridge over Weldon River, on top of right downstream concrete guardrail; Iowa Highway Commission bench mark.

Elevation $966.37 \mathrm{ft}$.

6924-20 SE (2)--Approximately 5.5 mi east of Leon, on State Highway 2 bridge over Weldon River, on left downstream wingwall; chiseled square.

Elevation $966.35 \mathrm{ft}$.

6924-20 SE (3)--(REFERENCE POINT) Approximately 5.5 mi east of Leon, on State Highway 2 bridge over Weldon River, on downstream guardrail and $90 \mathrm{ft}$ from left end of bridge; chiseled arrow.

Elevation $966.33 \mathrm{ft}$.

6926-31 NW (1)--Approximately 3.3 mi west of Decatur City, on State Highway 2 bridge over Thompson River, on right upstream wingwall; Iowa Highway Commission bench mark.

Elevation $945.38 \mathrm{ft}$.

6926-31 NW (2)--Approximately $3.3 \mathrm{mi}$ west of Decatur City, on State Highway 2 bridge over Thompson River, on left upstream wingwall; chiseled square.

Elevation $946.02 \mathrm{ft}$.
6926-31 NW (3)--(REFERENCE POINT) Approximately 3.3 mi west of Decatur City, on State Highway 2 bridge over Thompson River, on top of downstream concrete guardrail and at 2nd bridge deck drain from right end of bridge; chiseled arrow.

Elevation $945.57 \mathrm{ft}$.

6927-33 NE (1)--Approximately $6.3 \mathrm{mi}$ west of Decatur City, on State Highway 294 bridge over Elk Creek, on right upstream concrete curb, Iowa Highway Commission bench mark.

Elevation $982.91 \mathrm{ft}$.

6927-33 NE (2)--Approximately $6.3 \mathrm{mi}$ west of Decatur City, on State Highway 294 bridge over Elk Creek, on left upstream wingwall; chiseled square.

Elevation $978.76 \mathrm{ft}$.

6927-33 NE (3)--(REFERENCE POINT) Approximately $6.3 \mathrm{mi}$ west of Decatur City, on State Highway 294 bridge over Elk Creek, on downstream guardrail and 81 $\mathrm{ft}$ from left end of bridge; chiseled arrow.

Elevation $981.07 \mathrm{ft}$.

6927-34 SE (1)--Approximately 5.5 mi west of Decatur City, near right downstream side of County Road R 18 bridge over Elk Creek, set at ground level and $4 \mathrm{ft}$ landward of upstream landward side of gage house; U.S. Geological Survey brass bench mark.

Elevation $953.91 \mathrm{ft}$.

6927-34 SE (2)--Approximately 5.5 mi west of Decatur City, on County Road R18 bridge over Elk Creek, on right downstream wingwall; chiseled square.

Elevation $957.10 \mathrm{ft}$.

6927-34 SE (3)--Approximately $5.7 \mathrm{mi}$ west of Decatur City, on State Highway 2 bridge over Elk Creek, on right upstream concrete guardrail; Iowa Highway Commission bench mark.

Elevation $971.47 \mathrm{ft}$.

6927-34 SE (4)--Approximately $5.7 \mathrm{mi}$ west of Decatur City, on State Highway 2 bridge over Elk Creek, on left upstream wingwall; chiseled square.

Elevation $968.34 \mathrm{ft}$.

6927-34 SE (5)--(REFERENCE POINT) Approximately 5.7 mi west of Decatur City, on State Highway 2 bridge over Elk Creek, $90 \mathrm{ft}$ from right downstream end of bridge; chiseled arrow.

Elevation $969.92 \mathrm{ft}$.

7023-18 SE (1)--Approximately $2.2 \mathrm{mi}$ west of Humeston, on County Road J22 bridge over Chariton River, on right upstream wingwall; chiseled square.

Elevation $1056.02 \mathrm{ft}$. 
7023-18 SE (2)--Approximately $2.2 \mathrm{mi}$ west of Humeston, on County Road J22 bridge over Chariton River, on left upstream wingwall; chiseled cross.

Elevation $1056.03 \mathrm{ft}$.

7023-18 SE (3)--(REFERENCE POINT) Approximately 2.2 mi west of Humeston, on County Road J22 bridge over Chariton River, on fifth guardrail post from right upstream end of bridge; chiseled arrow.

Elevation $1057.63 \mathrm{ft}$.

7024-16 SW (1)--Approximately 2.4 mi northwest of Garden Grove, on County Road J22 bridge over Weldon River, on top of curb near left downstream wingwall; chiseled square.

Elevation $1018.73 \mathrm{ft}$.

7024-16 SW (2)--Approximately 2.4 mi northwest of Garden Grove, on County Road J22 bridge over Weldon River, on right downstream wingwall; chiseled square.

Elevation $1018.72 \mathrm{ft}$.

7024-16 SW (3)--(REFERENCE POINT) Approximately 2.4 mi northwest of Garden Grove, on County Road J22 bridge over Weldon River, on top of guardrail between 9 th and 10th guardrail posts from right downstream end of bridge; filed mark.

Elevation $1021.01 \mathrm{ft}$.

7024-33 SW (1)--Approximately $1.7 \mathrm{mi}$ southeast of Garden Grove, on County Road J20 bridge over Weldon River, on left downstream wingwall; chiseled square.

Elevation $994.57 \mathrm{ft}$.

7024-33 SW (2)--Approximately $1.7 \mathrm{mi}$ southeast of Garden Grove, on County Road J20 bridge over Weldon River, on right upstream wingwall; chiseled square.

Elevation $994.57 \mathrm{ft}$.

7024-33 SW (3)--(REFERENCE POINT) Approximately 1.7 mi southeast of Garden Grove, on County Road J20 bridge over Weldon River, on top of guardrail between 14 th and 15 th guardrail posts from left downstream end of bridge; filed mark.

Elevation $996.65 \mathrm{ft}$.

7027-16 NW (1)--Approximately $3.2 \mathrm{mi}$ north of Grand River, on County Road R15 bridge over Thompson River, on left downstream wingwall; chiseled cross.

Elevation $982.59 \mathrm{ft}$.

7027-16 NW (2)--Approximately 3.2 mi north of Grand River, on County Road R 15 bridge over Thompson River, on downstream concrete curb at 22nd guardrail post from right end of bridge; chiseled square.

Elevation $985.29 \mathrm{ft}$.
7027-16 NW (3)--(REFERENCE POINT) Approximately 3.2 mi north of Grand River, on County Road R15 bridge over Thompson River, on 22nd guardrail post from right downstream end of bridge; filed mark.

Elevation $986.99 \mathrm{ft}$.

7027-34 SE (1)--Approximately $0.5 \mathrm{mi}$ east of Grand River, on County Road $\mathbf{J} 20$ bridge over Thompson River, on right upstream wingwall; chiseled square.

Elevation $974.78 \mathrm{ft}$.

7027-34 SE (2)--Approximately 0.5 mi east of Grand River, on County Road J20 bridge over Thompson River, on curb at left downstream wingwall; chiseled cross.

Elevation $975.84 \mathrm{ft}$.

7027-34 SE (3)--(REFERENCE POINT) Approximately 0.5 mi east of Grand River, on County Road J20 bridge over Thompson River, on right side of 25th guardrail post from right downstream end of bridge; three chiseled marks.

Elevation $976.12 \mathrm{ft}$.

7028-36 NE (1)--Approximately $2.5 \mathrm{mi}$ west of Grand River, on County Road J20 bridge over Elk Creek, on left downstream wingwall; chiseled square.

Elevation $1065.40 \mathrm{ft}$.

7028-36 NE (2)--(REFERENCE POINT) Approximately $2.5 \mathrm{mi}$ west of Grand River, on County Road J20 bridge over Elk Creek, on downstream guardrail at 4th guardrail post from left end of bridge; filed mark.

Elevation $1065.60 \mathrm{ft}$.

7120-33 SW (1)--Approximately $5.3 \mathrm{mi}$ south of Russell, on County Road S56 bridge over Chariton River, on upstream corner of right upstream wingwall; chiseled square.

Elevation $932.94 \mathrm{ft}$.

7120-33 SW (2)--(REFERENCE POINT) Approximately 5.3 mi south of Russell, on County Road S56 bridge over Chariton River, on guardrail between 21 st and 22nd guardrail posts from right downstream end of bridge; chiseled arrow.

Elevation $934.96 \mathrm{ft}$.

7121-15 NE (1)--Approximately $5 \mathrm{mi}$ southeast of Chariton, on County Road S43 bridge over Chariton River, on end of right downstream concrete wingwall; top of 1-in. bolt.

Elevation 945.09 ft. 
7121-15 NE (2)--Approximately $5 \mathrm{mi}$ southeast of Chariton, on County Road S43 bridge over Chariton River, on right downstream abutment; chiseled square (U.S. Army Corps of Engineers).

Elevation $938.03 \mathrm{ft}$.
7228-17 SW (1)--Approximately $2.6 \mathrm{mi}$ west of Thayer, on U.S. Highway 34 bridge over Thompson River, on left downstream guardrail; Iowa Highway Commission bench mark.

Elevation $1059.32 \mathrm{ft}$.

7228-17 SW (2)--Approximately $2.6 \mathrm{mi}$ west of Thayer, on U.S. Highway 34 bridge over Thompson River, on right upstream wingwall; chiseled square.

Elevation $1059.59 \mathrm{ft}$.

7228-17 SW (3)--(REFERENCE POINT) Approximately $2.6 \mathrm{mi}$ west of Thayer, on U.S. Highway 34 bridge over Thompson River, $114 \mathrm{ft}$ from left downstream end of bridge; chiseled arrow.

Elevation $1057.65 \mathrm{ft}$.

7123-11 NE (3)--(REFERENCE POINT) Approximately $2.1 \mathrm{mi}$ north of Derby, on U.S. Highway 65 bridge over Chariton River, on downstream guardrail and $87 \mathrm{ft} \mathrm{from}$ left end of bridge; chiseled arrow.

Elevation $1008.22 \mathrm{ft}$.

7128-02 SW (1)--Approximately $3.7 \mathrm{mi}$ south of Thayer, on County Road P64 bridge over Thompson River, on right downstream wingwall; chiseled square.

Elevation $1025.12 \mathrm{ft}$.

7128-02 SW (2)--Approximately $3.7 \mathrm{mi}$ south of Thayer, on County Road P64 bridge over Thompson River, on left upstream wingwall; chiseled cross.

Elevation $1025.13 \mathrm{ft}$.

7128-02 SW (3)--(REFERENCE POINT) Approximately 3.7 mi south of Thayer, on County Road P64 bridge over Thompson River, on downstream guardrail and 92 $\mathrm{ft}$ from left end of bridge; two filed marks.

Elevation $1025.24 \mathrm{ft}$.

7221-32 SW (1)--Approximately $0.8 \mathrm{mi}$ south of Chariton, on State Highway 14 bridge over Chariton River, on left downstream wingwall; Iowa Highway Commission bench mark.

Elevation $962.53 \mathrm{ft}$.

7221-32 SW (2)--Approximately $0.8 \mathrm{mi}$ south of Chariton, on State Highway 14 bridge over Chariton River, on right downstream wingwall; chiseled square.

Elevation $962.40 \mathrm{ft}$.

7221-32 SW (3)--(REFERENCE POINT) Approximately $0.8 \mathrm{mi}$ south of Chariton, on State Highway 14 bridge over Chariton River, on downstream guardrail and 150 $\mathrm{ft}$ from left end of bridge; chiseled arrow.

Elevation $962.82 \mathrm{ft}$.
7429-17 SE (1)--Approximately $1.2 \mathrm{mi}$ southwest of Macksburg, on County Road G61 bridge over Thompson River, on right upstream wingwall; top of bolt.

Elevation $1129.70 \mathrm{ft}$.

7429-17 SE (2)--Approximately $1.2 \mathrm{mi}$ southwest of Macksburg, on County Road G61 bridge over Thompson River, on curb at left downstream wingwall; chiseled square.

Elevation $1128.53 \mathrm{ft}$.

7429-17 SE (3)--(REFERENCE POINT) Approximately 1.2 mi southwest of Macksburg, on County Road G61 bridge over Thompson River, on downstream guardrail and $75 \mathrm{ft}$ from left end of bridge; three filed marks.

Elevation $1130.72 \mathrm{ft}$.

7530-17 NE (1)--Approximately 6.7 mi east of Greenfield, on State Highway 92 bridge over Thompson River, behind guardrail on right downstream wingwall; Iowa Highway Commission bench mark.

Elevation $1193.84 \mathrm{ft}$.

7530-17 NE (2)--Approximately $6.7 \mathrm{mi}$ east of Greenfield, on State Highway 92 bridge over Thompson River, on left upstream wingwall and almost level with bridge deck; chiseled square.

7530-17 NE (3)--(REFERENCE POINT) Approximately 6.7 mi east of Greenfield, on State Highway 92 bridge over Thompson River, $132 \mathrm{ft}$ from left upstream end of bridge; chiseled arrow.

Elevation $1191.10 \mathrm{ft}$.
Elevation $1189.42 \mathrm{ft}$. 